
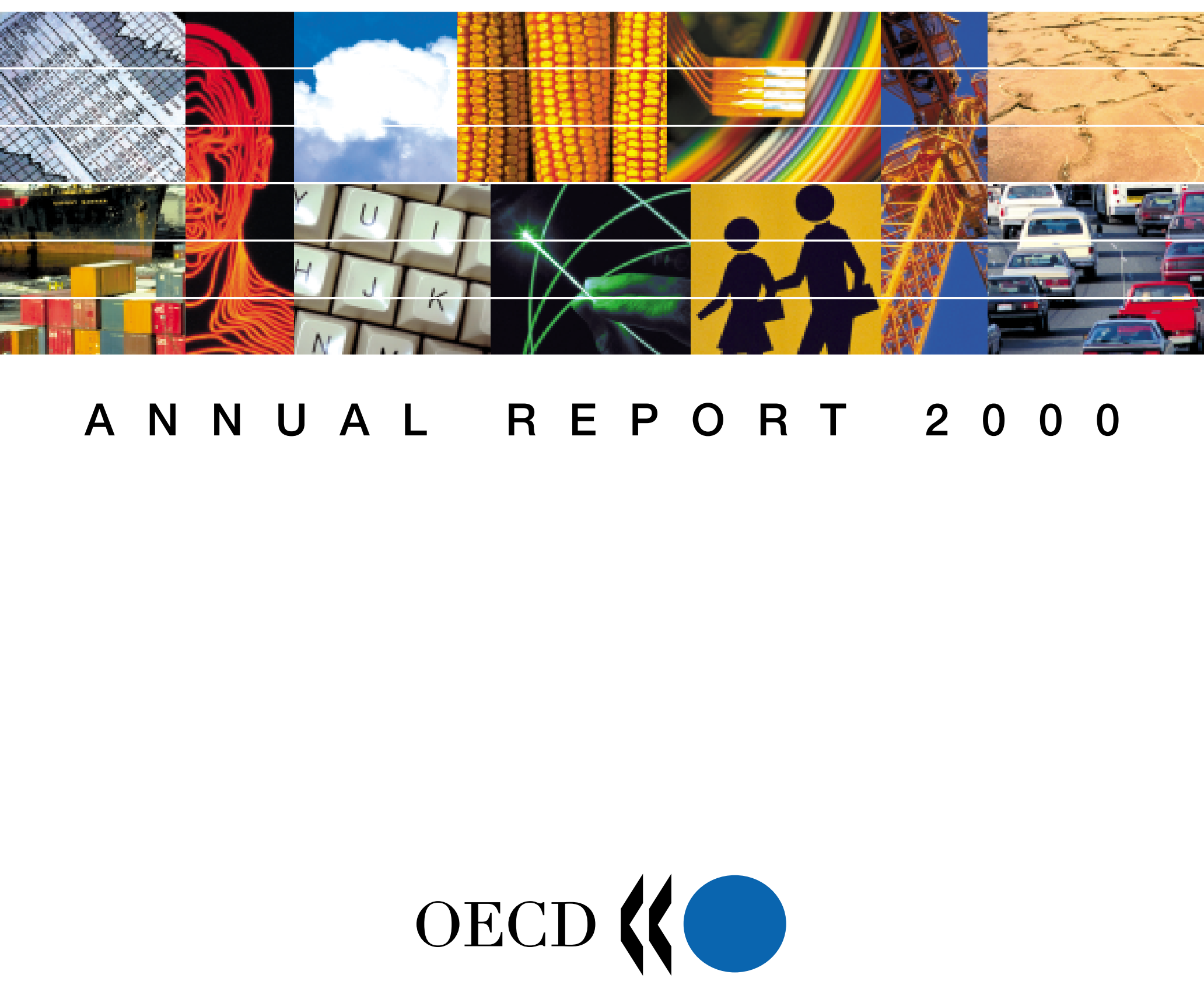

ORGANISATION FOR ECONOMIC CO-OPERATION AND DEVELOPMENT 


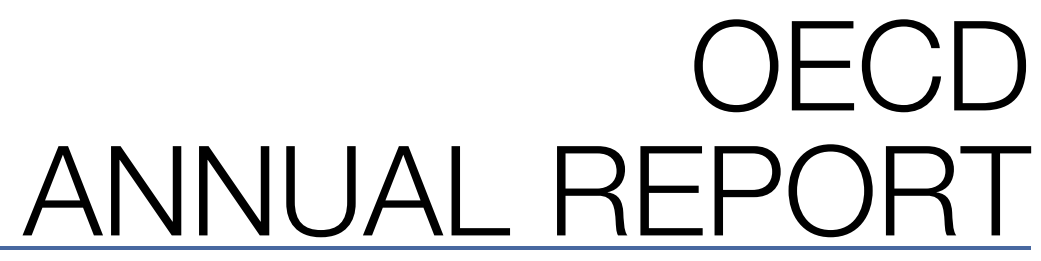

C C OECD 2000 
THE ORGANISATION FOR ECONOMIC CO-OPERATION AND DEVELOPMENT (OECD) ANNUAL REPORT is prepared by the Public Affairs Division, Public Affairs and Communications Directorate. It is published under the responsibility of the Secretary-General of the OECD. 
PREFACE

CHARACTERISTICS AND FUNCTIONS OF THE OECD

THE OECD IN 1999: SELECTED EVENTS

OECD COUNCIL MEETING

AT MINISTERIAL LEVEL - COMMUNIQUÉ

ECONOMIC AFFAIRS

THE OECD GROWTH PROJECT

STATISTICS

THE COMMITTEE, AN ESSENTIAL PART OF THE OECD MACHINERY

TRADE

FINANCIAL, FISCAL AND ENTERPRISE AFFAIRS

THE FIGHT AGAINST HARMFUL TAX PRACTICES 50

ENVIRONMENT

SUSTAINABLE DEVELOPMENT: PROGRESS OF THE OECD THREE-YEAR INITIATIVE

FOOD, AGRICULTURE AND FISHERIES

SCIENCE, TECHNOLOGY AND INDUSTRY

BIOTECHNOLOGY AND FOOD SAFETY

PUBLIC MANAGEMENT

REGULATORY REFORM

62
5 EDUCATION, EMPLOYMENT, LABOUR AND SOCIAL AFFAIRS

8 TERRITORIAL DEVELOPMENT SERVICE

9 CO-OPERATION WITH NON-MEMBERS

DEVELOPMENT CO-OPERATION

DEVELOPMENTAL POLICY COHERENCE

THE DEVELOPMENT CENTRE

CLUB DU SAHEL

INTERNATIONAL FUTURES PROGRAMME

INTERNATIONAL ENERGY AGENCY

NUCLEAR ENERGY AGENCY

100

EXECUTIVE DIRECTORATE

104

PROGRAMME OF WORK AND BUDGET

106

PUBLIC AFFAIRS AND COMMUNICATIONS

BUSINESS AND INDUSTRY ADVISORY COMMITTEE (BIAC) AND TRADE UNION ADVISORY COMMITTEE (TUAC)

OECD ORGANISATION CHART IN MARCH 2000117

67

THE OECD SECRETARIAT

AMBASSADORS, PERMANENT

68 REPRESENTATIVES TO THE OECD

71 OECD MEMBER COUNTRIES 



\section{PREFACE}

\section{Donald J. Johnston}

OECD Secretary-General

Being a champion of more open flows of goods, services and capital as a vehicle for increasing world economic growth and welfare, the OECD has a particularly important role to play in support of the globalisation process. But to deliver its promise, globalisation requires strong institutional and regulatory structures. Here, the OECD has developed a rich resource of codes, guidelines, knowledge and expertise of enormous value to its 29 Member countries. Today, this resource is of increasing importance to the economies of non-members.

Almost without exception, the core work designed by OECD Committees and Working Groups is of significance to non-members, as the following examples indicate.

\section{Trade and investment liberalisation}

More open markets are central to the interests of Members and non-members at all stages of development. There is much work planned and being carried out within the OECD which contributes to furthering this objective:

- In support of the work of the WTO, continuing analysis of the "trade and" issues, e.g. trade and competition policy, trade and environment, trade and labour standards, as well as foreign direct investment issues. And work on the linkages between the objective of trade and investment liberalisation, development and the coherence of policies in OECD Member countries.
- The compatibility of OECD Member policies on export credits with sustainable development objectives.

- An appropriate framework for the evolution of electronic commerce, one of the most exciting opportunities for the advancement of international trade.

- Corporate governance supported by public governance which, if adopted and applied by developing countries, will induce investors to put muchneeded capital into the developing world, while providing enhanced investment and trade opportunities for OECD Members.

- International taxation principles in general, but in particular the application of the principles contained in the 1998 Ministerial recommendations on Harmful Tax Competition.

\section{Focused policy reform and development}

There are specific regions of immediate concern where the OECD has an important contribution to make, areas which risk creating international destabilisation such as Russia and South Eastern Europe. The OECD's Russian programme is well under way and we have agreed with the World Bank to co-ordinate our efforts to maximise synergies. This is in line with earlier requests from Members to establish better linkages with other international organisations. 
Peace, stability, economic and social progress in South Eastern Europe are new challenges to the OECD, a founding member of the Stability Pact. The adoption of policies and institutions to achieve economic integration, especially through regional co-operation along the lines of the postwar European experience, is the direction in which Stability Pact members may wish to move. The OECD will utilise its rich assets of institutional and policy experience in a number of areas. Of these, the "South Eastern Europe Compact for Reform, Investment Integrity and Growth" is worthy of note. Its aim is to establish fair and non-discriminatory treatment of domestic and foreign investors, with full protection of property rights, not only in the letter of the law but also through administrative implementation and judicial enforcement. The OECD was invited by the members of the Stability Pact to oversee this initiative and its very ambitious agenda of legal, regulatory and institutional reforms.

\section{Managing new and evolving technologies}

As we enter the 21 st century, nearly all innovation and technological development take place within the OECD membership. Undoubtedly that will change as development brings more and more intellectual capital into the world mainstream of research and development and innovation. But it is up to the OECD membership to initiate the long-term groundwork for the approval, adoption and dissemination of beneficial technologies in close co-ordination and co-operation with interested non-members. Biotechnology may have a fundamental role in achieving long-term sustainability. But there are also concerns that vary in intensity across the OECD membership and beyond. Biotechnology and food safety are concerns of particu- lar significance. The OECD has been asked by the G8 to study the issues. Our report will be ready for the G8 Summit in Okinawa in July 2000.

\section{Public governance}

Governance has never been more important or more challenged. Governments are increasingly finding that they are just one set of players among many seeking to represent and serve the public. The loss of the government monopoly in services means that the public sector faces greater competition. At the same time, national governments must learn to co-ordinate with other centres of power, including international and sub-national levels of government, the media, industry and non-profit groups, in order to fully understand the issues and serve the public.

The increasing gap between public expectations and government services is emerging in the so-called democratic deficit. In order to keep up with expectations, government must anticipate the public's desires and make changes in how it does business in order to meet them. This is a challenging governance agenda for the next millennium and OECD must continue to work with Members and non-members in meeting that challenge.

\section{Social protection}

Too many people, even in the advanced societies of the OECD, are in danger of becoming permanently disconnected from society because they are unable to participate in the modern economy. Not only does this cause enormous personal distress, it imposes heavy direct economic costs on society. That is why social protection must address the needs of individuals and help countries to take full advantage of the human cap- 
ital potential they possess. In 1999, an OECD study, A Caring World: The New Social Policy Agenda, assessed ways to design systems of protection that can meet today's social and economic challenges. Its main lesson - that social protection is only effective if it is "active", provides encouragement and helps the displaced to find employment - merits wide application and continuing attention at the OECD.

While the foregoing are the areas where I believe OECD's efforts should be concentrated, other areas of importance to Members will continue to receive emphasis.

- Ongoing analytical work across the house underpins the ability of the Secretariat to support continuous dialogue with officials from capitals. Without it, specific projects, e.g. corporate governance, could not be launched.

- Work flowing from ministerial mandates, including the investigation under way of the sources of economic growth.

- Work already launched which has the necessary momentum but requires continuing analysis, monitoring and sometimes some maintenance and updating. The Jobs Strategy, ageing, sustainable development, the Anti-Bribery Convention and regulatory reform fall into this category.

Since the May 1996 Ministerial meeting, the will to reform has been the guiding principle for OECD management. The fundamental objective of the reform programme has been the creation of a more responsive, efficient and relevant OECD that is in tune with the evolving challenges facing Member countries. Much has been accomplished in recent years, including administrative efficiencies and productivity gains that have generated significant cost savings for OECD go- vernments. The reform of the Organisation will continue to receive high priority in the period ahead.

As we look forward to the $21^{\text {st }}$ century, let us raise our sights to embrace the world, not just the OECD. Business, governments and non-governmental organisations are doing this, and so must we in response to our Members' interests. Much more needs to be done to ensure that the work of the OECD finds a global audience and that policy dialogue grows as a productive two-way instrument in areas of mutual interest.

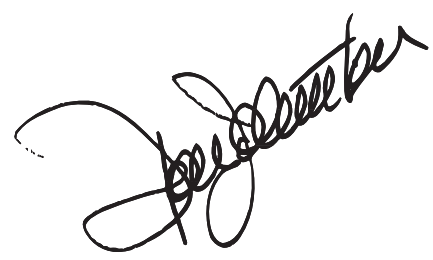




\section{CHARACTERISTICS AND FUNCTIONS OF THE OECD}

OECD was founded in 1961, replacing the Organisation for European Economic Co-operation (OEEC) which had been established in 1948 in conjunction with the Marshall Plan. The OECD brings together 29 Member countries in a unique forum in which to discuss, develop and perfect economic and social policy. Members compare experiences, seek answers to common problems and work to co-ordinate domestic and international policies that increasingly in today's globalised world must form a web of even practice across nations. The characteristics and functions of the OECD are:

- It is an intergovernmental economic organisation, global (though not universal) in its membership, relying on sound and objective policy analysis, confidential dialogue and peer pressure between public officials to promote international co-operation and collaboration to improve public policy.

- It is "economic" in the broadest sense, OECD work mirroring most of the policy concerns of governments, with expertise in the full range of economic, social and institutional issues, including governance itself.

- It has the capacity to reach beyond national governments to address public policy-makers at all levels and brings together all those who have an impact on policy-making.

- Its membership enjoys a high degree of homogeneity in that all Member countries are presumed to share common economic and democratic principles and respect for human rights.

- The global nature of membership ensures an Asia-Pacific/North American/European interaction across the full range of economic/social issues available in no other forum, allowing the OECD to address "system frictions" on a global scale. This includes an increasing capacity for interaction and dialogue with many non-members in all regions of the world.

- Its policy prescriptions are tested across many different disciplines in many countries, which enhances their credibility and broad acceptance.

- Close interaction between the Secretariat and national governments is a hallmark of OECD work which has permitted the successful application of a multidisciplinary approach to a host of complex issues.

For almost 40 years the Organisation has been one of the world's largest and most reliable sources of comparable statistical, economic and social data. The data received from governments are harmonised and rendered comparable to facilitate comparison and analysis. OECD databases span areas as diverse as national accounts, a range of economic indicators, the labour force, trade, employment, migration, education, energy, industry, taxation, tourism and the environment. 


\section{THE OECD IN 1999: SELECTED EVENTS}

\section{JANUARY}

\section{Anti-corruption directory}

A directory of national and international anti-corruption programmes operating in Central and Eastern Europe, jointly produced by the OECD and Transparency International, goes live on the Internet. Thirteen countries are covered in the 40-page directory.

\section{EMU: facts, challenges and policies}

Economic experts from OECD Member countries discuss the challenges facing the newly created European Monetary Union.

\section{Investment and environment}

An OECD conference, held in The Hague, analyses the key issues in the relationship between foreign direct investment and the environment.

\section{FEBRUARY}

\section{New international treaty aimed at combating bribery and corruption}

The Convention on Combating Bribery of Foreign Public Officials in International Business, negotiated under the auspices of the OECD in 1997, enters into force on 15 February 1999.

\section{Money laundering}

The Financial Action Task Force on money laundering, which includes 28 Member countries and organisations and has its Secretariat at the OECD, releases its latest report on international money laundering.

\section{Fighting corruption: what role for the private sector}

How the private sector can help in the fight against corruption in developing countries is discussed at an international conference organised by the

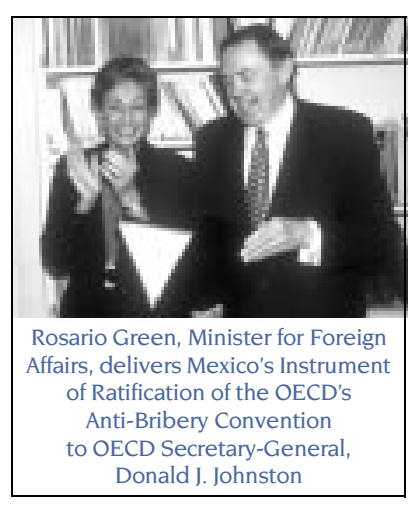
OECD Development Centre in Washington DC. 


\section{Russia}

Secretary-General Johnston holds talks with Russian Prime Minister Primakov.

\section{New Chairman of DAC}

Mr. Jean-Claude Faure, a senior French civil servant, becomes Chair of the OECD Development Assistance Committee (DAC).

\section{Conference on youth unemployment, Washington, DC}

The OECD and the US Departments of Labor and Education hold a conference, chaired by former US Secretary of Labor Ray Marshal, to address the problems facing young people entering the labour market and review current policies directed at aiding them to find and stay in work.

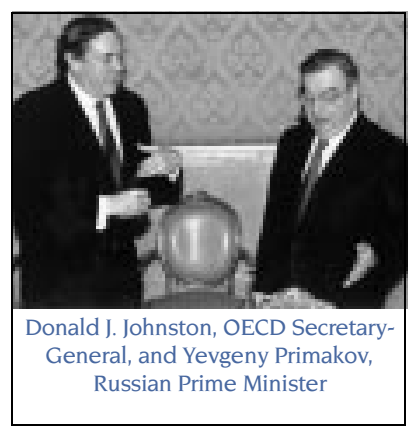

\section{MARCH}

\section{Corporate governance in Asia}

Officials from finance ministries, supervisory authorities, stock exchanges and business discuss ways to improve corporate governance in emerging Asian markets at a conference in Seoul organised by the OECD with the Korean Development Institute, and co-sponsored by the Government of Japan and the World Bank.

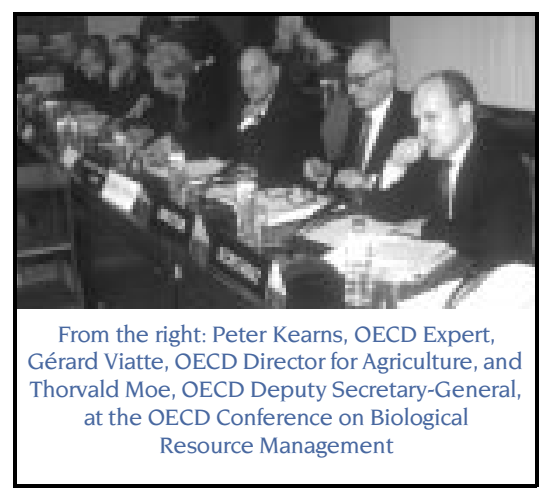

vate sector and non-governmental organisations discuss the key outcomes of the 4 th Conference of the Parties to the UN Framework Convention on Climate Change and equitable approaches to global participation to reduce greenhouse gas emissions.

\section{OECD conference on biological resource management}

Governments, business, scientists, academics, representatives of consumer organisations and specialist journalists look at the possible contribution of biotechnology to sustainable development.

\section{Current challenges for macroeconomic policy and structural reforms in Russia}

Secretary-General Donald J. Johnston chairs a meeting of the OECDRussia Liaison Committee to review the outlook for Russia's economy and examine ways in which the OECD can respond to Russia's economic problems.

\section{Forum on climate change}

Representatives of OECD and non-member governments, the pri- 


\section{OECD and China}

A memorandum of understanding is signed with China covering the discussion of investment matters.

\section{International organisations co-operate to produce statistics on external debt}

The first of a new series of quarterly releases of statistics on external debt for 176 developing and transition countries is jointly published by the BIS, the IMF, the OECD and the World Bank.

\section{APRIL}

\section{Corporate governance}

The OECD Task Force concludes its work on the development of OECD Principles of Corporate Governance. The Principles are submitted to OECD Ministers at their annual meeting in May.

\section{OECD-China environmental co-operation}

At a seminar in Beijing, experts from China, OECD countries and the Secretariat discuss ways to modernise systems of environmental monitoring in China.

\section{Steel market examined}

At its April meeting, the OECD Steel Committee identifies significant distortions of steel trade flows, sharp declines in steel prices, and increases in steel inventories as the main impact on the world steel market of the economic crisis that began in East Asia in 1997. A decline in world steel demand and a contraction of trade are forecast.

\section{MAY}

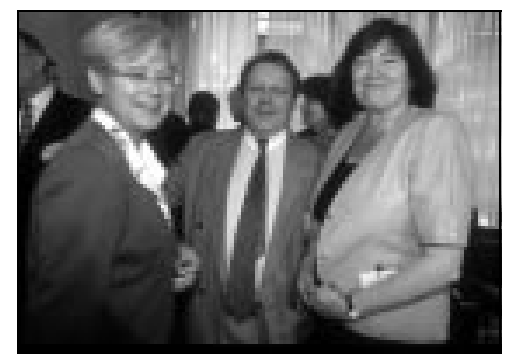

Evelyn Herfkens, Minister for Development Cooperation, Netherlands, J. C. Faure, DAC Chairman, and Clare Short, Secretary of State for International Development, UK

\section{High-level meeting of the Development Assistance Committee (DAC)}

Development Co-operation Ministers and agency heads support new initiatives for a better co-ordinated international aid system based on partnership. They back the efforts of developing countries to participate effectively in the global economy.

\section{Science and technology labour markets}

A Paris workshop analyses human resources in science and technology, particularly the growing demand for IT workers, increased international mobility of researchers, and government and business efforts to train workers for the knowledge economy. 


\section{Special Ministerial Dialogue}

Immediately prior to their annual gathering, Ministers of the Economy, Finance, Foreign Affairs and Trade of OECD countries hold a Special Ministerial Dialogue with representatives of seven non-member countries.

\section{Meeting of the Council at Ministerial level}

The Ministerial Council meeting discusses economic perspectives and policy requirements; the multilateral system and a new WTO round; governance; relations with non-members; South Eastern Europe; and development.

\section{JUNE}

\section{Corporate governance and Russia}

At a meeting in Moscow organised by the OECD and co-sponsored by the World Bank and the US Agency for International Development, the OECD and the World Bank set up a Corporate Governance Round Table with Russia.

\section{National economic research organisations}

OECD experts and heads of national economic research organisations exchange views on current economic trends and emerging issues.

\section{New GDP comparisons}

The OECD publishes real GDP per capita based on purchasing power parities rather than exchange rates for an expanded group of 52 countries.
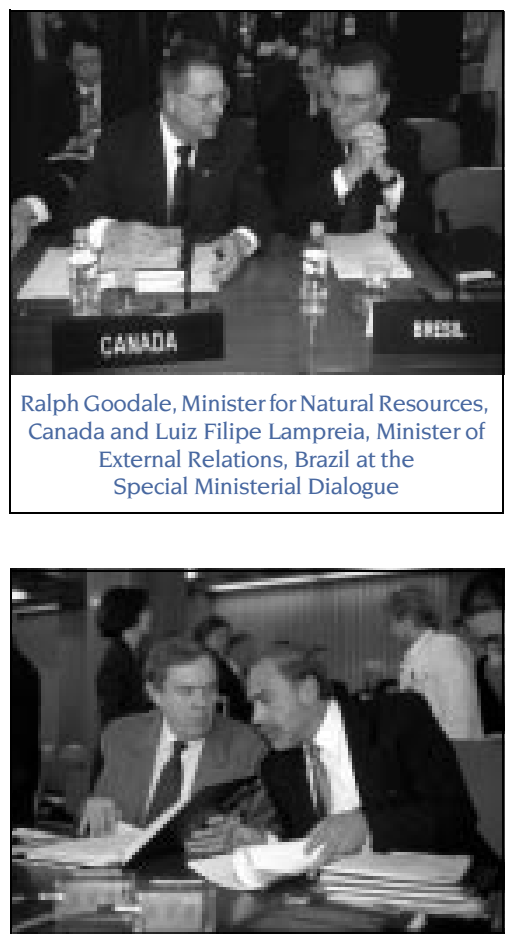

Donald J. Johnston, OECD Secretary-General, with José Angel Gurría, Minister for Budget and Finance, Mexico, Chair of the OECD Ministerial Council Meeting

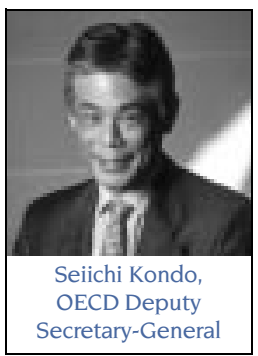

\section{Deputy Secretary-General named}

Seiichi Kondo, a senior Japanese diplomat, is appointed a Deputy Secretary-General of the OECD.

\section{Intellectual capital}

An OECD symposium in Amsterdam on measurement of intellectual capital, organised with the co-operation of the Dutch Ministries of Economic Affairs and Education, Culture and Science, and the Nordic Investment Council, brings together company executives, government officials and accountants. 


\section{Science and technology Ministers meet}

The Contribution of Science and New Technology to Sustainable Growth and Social Well-Being: New Opportunities and Policy Challenges is the theme of the meeting of OECD's Committee for Scientific and Technological Policy at Ministerial level.

\section{Conference on trade and competition}

Sir Leon Brittan, Vice-President of the European Commission, and US Assistant Attorney General Joel Klein are keynote speakers at the conference attended by government officials from OECD Member countries and 30 non-member countries, plus academics and representatives of business, trade unions and advocacy groups.

\section{JULY}

\section{Money laundering}

The Financial Action Task Force (FATF) marks its tenth anniversary by announcing that Argentina, Brazil and Mexico have been invited to the join the Task Force as observers.

\section{Fighting corruption in Russia}

At a workshop in greater Novgorod, the OECD and Russian private sector, non-governmental organisations as well as government authorities agree to work together to fight corruption.

\section{Sarajevo Summit}

In a speech at the Summit marking the signature of the Stability Pact, Secretary-General Johnston underscores that the OECD is one of the instruments at the disposal of the international community for the reconstruction of South Eastern Europe.
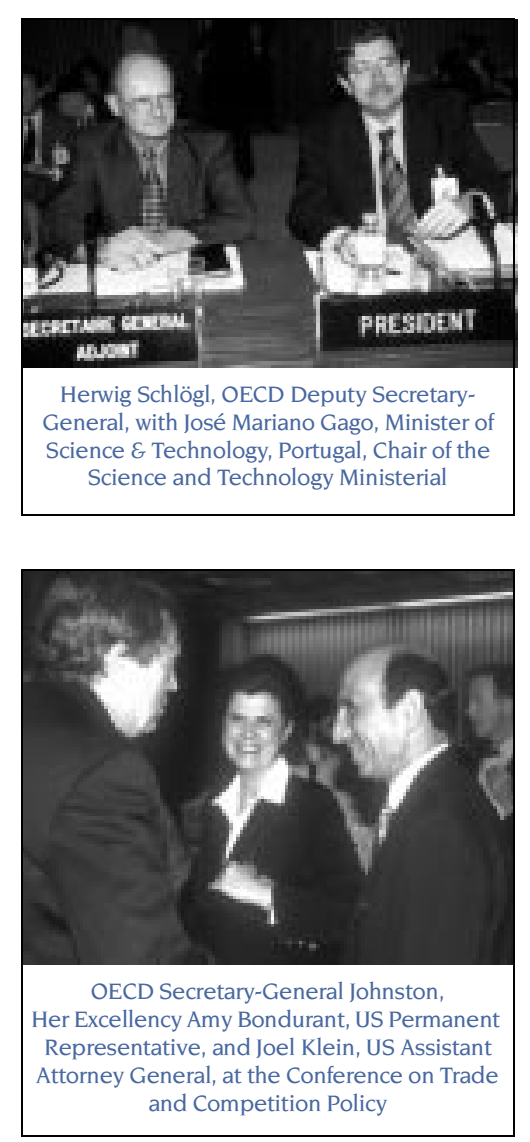

\section{AUGUST}

\section{Environmental information}

The OECD Working Party on Export Credits and Credit Guarantees announces an agreement between OECD Member governments on measures to promote a more comprehensive exchange of information on the environmental impact of large, multi-sourced projects in environmentally sensitive sectors. 


\section{SEPTEMBER}

\section{Information and communications technologies in schools}

The OECD network of national research experts meets in Poitiers, France to discuss ways of ensuring that students are equipped for the "knowledge societies" of the $21^{\text {st }}$ century.

\section{Secretary-General Donald J. Johnston in China}

During an official visit to China, OECD Secretary-General Donald J. Johnston addresses the Third China Fair for International Investment and Trade. Chinese government officials and the OECD Secretariat agree to enhance their co-operation.

\section{Making work pay}

A workshop attended by prominent academics and policymakers from OECD countries discusses policy measures to improve the employment income situation of people with low earnings capacity.

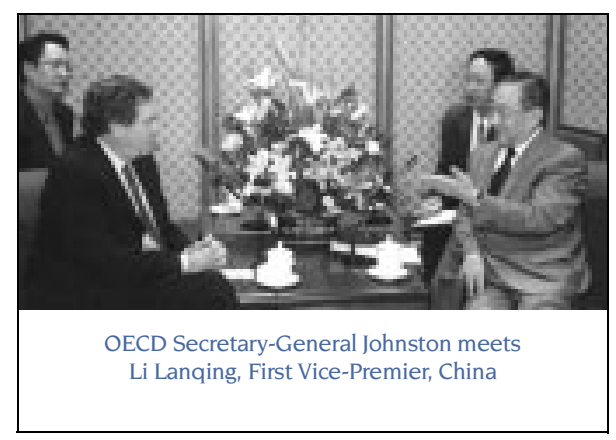

\section{Kyoto Protocol}

Policy-makers from finance and environment ministries meet on options to implement the Kyoto Protocol and preparations for the 5th Conference of the Parties to the UN Framework Convention on Climate Change.

\section{Investment, development and corporate responsibility}

Over 200 participants attend an OECD conference organised with the support of the Department for International Development of the United Kingdom.

\section{The service economy}

Government officials, experts and business and trade union leaders from 30 countries address issues related to realising the potential of the service economy: facilitating growth, innovation and competition at a business and industry policy forum.

\section{Integrating social and environmental policies}

Government representatives and experts meet in Paris to discuss the interface of social and environmental policies.

\section{Co-operation with the Sahel countries}

At its bi-annual conference at Yverdon-les-Bains, France, the Club du Sahel examines reform of development cooperation practices at national and local levels and the strengthening of Club members' political commitment. 


\section{Multilateral trading system}

Trade experts from OECD Member countries and from 25 non-member economies attend a workshop on barriers to trade in goods and services in the Post-Uruguay context.

\section{Workshop on combating corruption}

Senior officials and leading representatives from the business sector and civil society share views and experiences on efforts to fight corruption on the national and international level at a workshop in Manila sponsored by the Asian Development Bank and the OECD.

\section{OCTOBER}

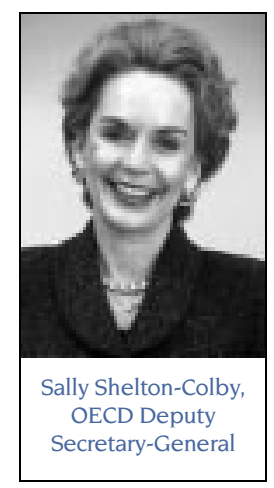

\section{Deputy Secretary-General named}

Sally Shelton-Colby, a senior US government official, is appointed a Deputy SecretaryGeneral of the OECD.

\section{Paris forum on electronic commerce}

Representatives of governments, business, civil society and international organisations take stock of the first year's achievements of the Action Plan for electronic commerce agreed upon at the Ottawa Ministerial Conference of October 1998.

\section{OECD Secretary-General Johnston in Australia}

At the invitation of the government, OECD Secretary-General Johnston pays an official visit to Australia to discuss the Australian government's policy priorities.

\section{New president for OECD's Development Centre}

Jorge Braga de Macedo, a former finance minister of Portugal, is named president of the Development Centre.

\section{Environment and trade}

At a workshop in Paris, government policy-makers from trade and environment ministries and representatives of international organisations, NGOs and academia explore methodologies for the environmental assessment of trade liberalisation agreements.

\section{International shipping principles}

The OECD Maritime Transport Committee concludes an understanding with the dynamic non-member economies on principles to be applied to international shipping.

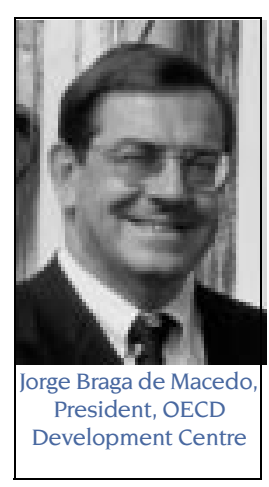




\section{NOVEMBER}

\section{The steel industry in the NIS}

Representatives from Belarus, China, India, Kazakhstan, Romania, Russia, the Slovak Republic and Ukraine, and several international organisations, take part in a workshop on the development of the steel sector in the NIS countries.

\section{Improving statistical systems}

At a joint UN/OECD/World Bank/IMF senior expert meeting, developing countries and donors launch a shared international strategy, PARIS2 1 (PARtnerships In Statistics for development in the $21^{\text {st }}$ century), to ensure adequate funding and support for national statistical systems.

\section{FDI policy and private sector development in the Baltic States}

Government officials and experts from the Baltic Sea region and OECD Member countries, as well as representatives of business and labour and academic circles, participate in this conference organised in Tallin with the support of the Estonian Investment Agency.

\section{Global finance and Latin America}

Policy-makers from Latin American and OECD countries discuss and evaluate current proposals to reform the international financial system at the jointly organised OECD Development Centre/Inter-American Development Bank $10^{\text {th }}$ Annual International Forum on Latin American Perspectives.

\section{Food safety}

OECD Secretary-General Donald J. Johnston holds consultations with representative non-governmental organisations on new OECD initiatives on biotechnology and other aspects of food safety.

\section{Seattle World Trade Organization (WTO) meeting}

The Secretary-General and other senior OECD officials attend the WTO's Ministerial session in Seattle.

\section{Budgeting and financial management}

Officials from the Chinese Ministry of Finance, the national People's Congress, the People's Bank and the State Development Planning Commission attend an OECD seminar in Beijing designed to familiarise Chinese officials with budgeting and management practices in OECD Member countries.

\section{Insolvency regimes in Asia}

Senior policy-makers, members of the judiciary, private sector practitioners, insolvency experts and academics from the Asian region and OECD Member countries meet in Sydney, Australia and recommend measures to strengthen insolvency systems. 


\section{DECEMBER}

\section{Productivity growth}

In the context of the project on growth, a workshop bringing together leading academics examines recent productivity trends and the impact of computers and information technology on economic growth.

\section{Social change in the coming decades}

The OECD Forum for the Future brings together senior ministers, business leaders and prominent academics to discuss the long-term prospects for dynamic social change, especially in the light of the emergence of the knowledge economy and increasing global integration.

\section{Innovation and technology policy}

An OECD Workshop on Research-Based Spin-Offs explores the importance of spin-offs as a mechanism for technology transfer and the effectiveness of policies to promote their development.

\section{Development aid}

Greece becomes a full member of the OECD's Development Assistance Committee.

\section{Consumers and e-commerce}

The OECD Council approves Guidelines for Consumer Protection in the Context of Electronic Commerce, designed to help ensure that consumers are no less protected shopping online than when buying from traditional suppliers.

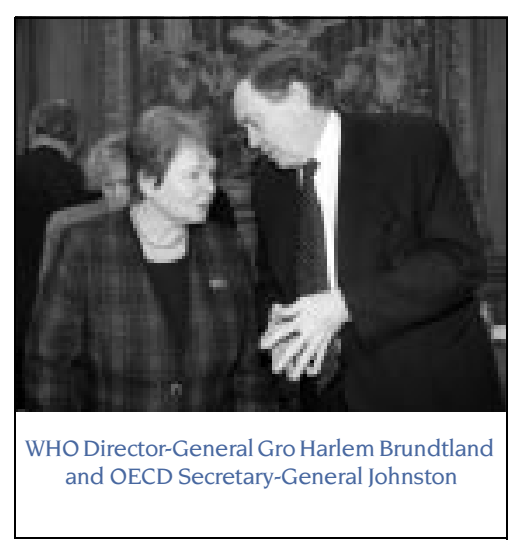

\section{OECD-WHO framework for co-operation}

WHO Director-General Gro Harlem Brundtland meets OECD SecretaryGeneral J. Johnston and representatives of OECD Member governments to discuss co-operation on health data and research, and further strengthening of relations between the two organisations.

\section{Indicators for sustainable development}

An OECD conference, hosted by the Italian Government in Rome, looks at how a range of indicators can be used for measuring progress towards sustainable development, both nationally and internationally.

\section{Guidelines for multinational enterprises}

A draft of the Revision of the Guidelines for Multinational Enterprises is posted on OECD's Internet site for public consultation and comment. 


\section{OECD COUNCIL MEETING AT MINISTERIAL LEVEL COMMUNIQUÉ}

The OECD Council at Ministerial level met on 2627 May 1999, under the chairmanship of Mr. Angel Gurría, Minister of Finance of Mexico, assisted by the vice-chairs, Mr. Giuliano Amato, Minister of the Treasury, Budget and Economic Planning of Italy, and Mr. Leszek Balcerowicz, Vice Prime Minister and Minister of Finance of Poland. Also on 26 May, in advance of the Council, OECD Ministers held a Special Dialogue with Ministers from seven non-member countries: Argentina, Brazil, China, India, Indonesia, Russia and the Slovak Republic. Consultations were held with the Business and Industry Advisory Committee (BIAC) and the Trade Union Advisory Committee (TUAC) to the OECD.

\section{Economic perspectives and policy requirements}

Ministers welcomed the policy steps taken by both OECD and non-OECD countries that have improved confidence and contributed to greater stability in world financial markets. But serious challenges remain and governments must not be complacent. Ministers stressed the need for both sound macroeconomic policies oriented toward non-inflationary growth and structural policies that promote competitive, flexible markets. Such policies are mutually reinforcing and foster strong economic performance which creates jobs and combats social problems.
Ministers agreed that stronger and more balanced growth among the main OECD regions and vigorous structural reforms are needed to reduce current account imbalances, lower unemployment, and support recovery in crisis-affected emerging economies. Momentum to strengthen the international financial architecture must be maintained to complement efforts at the national and regional levels to ensure a stable environment for growth and recovery.

Performance both within the OECD area and elsewhere has been mixed. Strong non-inflationary growth has continued in the United States and several other countries. While the individual country outlooks in Europe differ somewhat, overall economic expansion has slowed but is forecast to pick up later this year. In Japan, important policy steps have been taken, including the recapitalisation of major banks. The Japanese economy now shows some signs of improvement, but the short-term outlook remains uncertain. Some Asian crisis countries, notably Korea, have started to recover more rapidly than expected, thanks to supportive macroeconomic policies, more open and better supervised banking and financial markets, and other structural reforms which must be carried through. Most countries in Central Europe have managed recent market turbulence well and avoided lasting damage to their economies from the Russian crisis. In a number of other non-OECD emerging and tran- 
sition economies, however, the situation continues to require attention. Overall, growth in both the OECD area and the world economy remains unsatisfactory.

Ministers agreed that the markedly different cyclical situations in major OECD economies call for different economic policy settings:

- In the United States, where temporary and structural factors have facilitated the combination of rapid growth and job creation with good inflation performance, the authorities must continue to maintain sound policies and remain vigilant for signs of overheating.

- In Europe, where the euro has been successfully launched, the recent reduction of interest rates served as a stimulus for growth. An appropriate mix of macroeconomic policies and vigorous structural measures aimed at strengthening prospects for improved growth and higher employment must be pursued.

- In Japan, it is essential that policies be supportive until deflationary pressures ease and a revival of domestic demand-led growth is firmly under way. The Japanese authorities are committed to resolving the problems of the financial sector, including by encouraging banks to dispose more actively of non-performing assets, and to implementing further wide-ranging structural reforms essential to recovery and long-term growth.

Growth performance varies considerably across and within OECD countries. Ministers asked the OECD to study the causes of growth disparities, and identify factors and policies (such as rapid technological innovations and the growing impact of the knowledge society and its demand on human capital, the arrival of new service industries, the best framework conditions for fostering the start-up and growth of new enterprises including SMEs...) which could strengthen long-term growth performance.

Ministers expressed their concern at the continuing high levels of unemployment in some of their countries. Experience shows that unemployment can be durably reduced through a comprehensive and sustained package of reforms consistent with the OECD Jobs Strategy. Ministers underlined their determination to further implement the Strategy. High and persistent joblessness, especially among young people, women, older workers, and unskilled immigrants, remains a major policy challenge for most OECD governments. The best way to foster employment of these groups is through a combination of macroeconomic and structural policies aimed at increasing overall employment. Policy must promote flexible labour markets in tandem with effective social safety nets that deliver assistance to the most vulnerable members of society. Attention should also be given to policies to improve the employment prospects of groups at the margin of the labour market, to address regional disparities in employment performance, to reforms of the tax and benefit systems to make work pay, and to making life-long learning a reality for all. Fostering a climate conducive to "active ageing" also remains a priority. Progress across the board is needed to improve social cohesion. Ministers asked OECD to continue its work of monitoring and evaluation of the Jobs Strategy. 
The pursuit of sustainable development, including global challenges such as climate change, the sustainable management of natural resources, and the conservation of biodiversity, is a key objective for OECD countries. Achieving this objective requires the integration of economic, environmental and social considerations into policy-making, in particular by the internalisation of costs, and the development and diffusion of environmentally sound technologies world-wide. OECD will continue to promote discussions between economic and environment officials on how best to meet Kyoto commitments. Developing a set of key indicators is essential to assess progress towards sustainable development. OECD countries will continue to co-operate with non-OECD countries to improve policy and institutional frameworks. OECD will report to Ministers, with policy recommendations, in 2001.

\section{The multilateral system and a new WTO round}

Trade and investment are the motor of global economic growth, prosperity and integration, and are fundamental to the reduction in global poverty. The multilateral trading system is a keystone of the world economy. An open, transparent and rulesbased trading system remains essential. Countries must resist protectionist pressures and develop the momentum for further liberalisation by building on current levels of market access. Early conclusion of a second Information Technology Agreement (ITA-2) would contribute to this momentum. Considering the importance, for both developed and developing countries, of the ongoing Geneva negotiations on transparency in government procurement, Ministers aim for a substantive agreement by the Seattle Conference. Early accession of applicants to the WTO on the basis of mutually acceptable and commercially viable market access commitments and adherence to WTO rules would strengthen the system.

Ministers recognised the need to continue to settle trade disputes in accordance with WTO rules and the responsibility resting on governments in this regard. A better-functioning and more transparent WTO Dispute Settlement Understanding is vital. Ministers will aim with their WTO partners at a successful and timely conclusion of the review of the Understanding in the WTO as scheduled. The dispute settlement system must remain responsive to the needs of developing countries, and Ministers confirmed the importance of exploring the most effective means of providing assistance to developing countries to use more effectively the dispute settlement system.

Ministers endorsed the need for a new WTO round of multilateral trade negotiations, and will work constructively with all WTO members toward its successful launch in Seattle at the end of this year. They will work for an ambitious, broad-based and balanced agenda for the negotiations that responds to the needs and aspirations of all. Ministers agreed to aim to achieve timely results, preferably in three years, and to work with WTO members to reach agreement on options and modalities for negotiations, including the principle of a "single undertaking" and the possibility of achieving results in the course of negotiations. Increasing integration and participation of developing and transition countries in the multilateral trading system remain a priority for OECD governments. The new round must be 
responsive to the needs of all developing countries, through capacity-building, to ensure their economic growth and that they fully reap the gains of liberalisation; in this respect, particular emphasis must be given to the special needs of least developed countries, including improved market access.

Ministers stressed the importance of both effective implementation of existing WTO agreements and, as an integral part of the new round, the negotiations mandated in the "built-in agenda", which includes agriculture and services. In addition, further liberalisation of non-agricultural tariffs, removal of nontariff barriers, trade facilitation and expansion of government procurement opportunities would enhance market access on a broader front, and produce substantial benefits for all participants. The WTO must also remain fully responsive to the changing needs of the global economy and society. Ministers consider it essential that the WTO contribute to sustainable development as agreed in Marrakech, including through appropriate account being taken of environmental issues in the future trade negotiations. The current WTO work programmes on Trade $\mathcal{E}$ Investment and Trade $\mathcal{E}$ Competition as established in Singapore have been constructive. In the preparations for the Seattle Ministerial, their results should provide the WTO General Council with a basis for building consensus on appropriate recommendations to the third WTO Ministerial Conference that may be desirable to enhance the rulesbased multilateral trading system.

Ministers renewed their support for the observance of internationally recognised core labour standards.
They reaffirmed their rejection of the use of labour standards for protectionist purposes. They welcomed the work of the ILO to promote the new Declaration on Fundamental Principles and Rights at Work. Ministers supported continued co-operation between the ILO, WTO and OECD Secretariats and stressed the importance of facilitating a broader understanding on the issues concerned, in and among Member countries. They recognised that promoting respect for labour rights and trade and investment liberalisation, together with good governance, each contribute to better overall living conditions.

Ministers stressed the importance of ensuring enhanced transparency and clarity in the functioning of the WTO system. Active and constructive communication and consultation with civil society are essential for public understanding of the benefits and challenges of liberalisation. Ministers supported the important analytical work of the OECD in support of the multilateral system, and future WTO negotiations in particular. They encouraged OECD to make the results of its work available to a wider audience in order to help inform public debate.

Ministers urged the early ratification of the OECD Shipbuilding Agreement by all participants to establish normal competitive conditions within the international shipbuilding market and to encourage other countries to become parties to the Agreement. OECD should continue its work on improving transparency of the shipbuilding market.

Ministers ${ }^{1}$ welcome the establishment of the Forum on Harmful Tax Practices, the progress made in

1. See the report "Harmful Tax Competition - An Emerging Global Issue" 
implementing the mandate of the Forum and look forward to receiving a report on the identification of tax havens at their next meeting.

Ministers also welcome the dialogue initiated between the OECD and the Financial Action Task Force to explore how anti-money laundering systems could contribute effectively to deal with taxrelated crimes, without undermining the effectiveness of these systems.

Electronic commerce presents great opportunities for growth and jobs in the global economy. OECD's Action Plan on electronic commerce endorsed at the Ministerial Conference held in Ottawa in October 1998 provides a basis for further policy discussion and technical analysis, in consumer protection, privacy and security, communication infrastructures, authentication and taxation, together with deepened understanding of the economic and social impacts of electronic commerce. Ministers stressed the importance of maintaining a collaborative approach with civil society, including the private sector, and other international organisations and welcomed the followup conference to be held in October 1999 to report progress and assess priorities.

Ministers regretted that the Participants to the Export Credit Arrangement had not yet reached agreement on an Understanding covering agriculture as mandated in the Uruguay Round. They urged, once more, the Participants to intensify their efforts to conclude this Understanding promptly, if possible by the Seattle Conference, and to report back at the next Ministerial Council Meeting. They welcomed the progress towards the OECD Agreement on Environmental Information Exchange for Larger Projects in relation to officially supported export credits and urged that the work continue with a view to strengthening common approaches and to report on progress made at the next Ministerial Council Meeting.

Agriculture remains of central importance. While progress has been made in agricultural policy reform, more needs to be done: overall levels of support and protection remain high; trade disputes and tensions persist; and the sector is of key interest to developing countries. Ministers agreed to continue their efforts to implement the broad set of shared goals and policy principles for agricultural policy reform, and recognised: the multifunctional characteristics of the sector; the need to ensure that agro-food policies are targeted, transparent, costeffective and avoid distortion of production and trade; and the long-term objective of substantial progressive reductions in support and protection resulting in fundamental reform, as agreed by OECD Agriculture Ministers in March 1998 and as noted by the OECD Ministerial Council in April 1998.

Effective and sustainable management of fishery resources and the relationship between resource management and trade require timely international agreement and action. Ministers welcomed the FAO's International Plan of Action for the Management of Fishing Capacity, and endorsed OECD's ongoing examination of the impacts of government financial transfers and other relevant factors on fishery resources sustainability, including over-fishing.

Biotechnology offers great opportunities but also presents significant challenges and has given rise to public debate on its implications. Ministers stressed the importance of safeguarding human health and the environment while enabling people to enjoy the 
benefits that flow from advances in biotechnology. Scientific research is essential to the process. The OECD should continue to examine the various dimensions of this issue, including in the discussion at the forthcoming CSTP Ministerial and in other fora.

The OECD recognised at an early stage the serious impact $\mathrm{Y} 2 \mathrm{~K}$ disruptions could have on the global economy. Ministers welcomed OECD efforts to draw the attention of governments and the private sector, particularly SMEs, to this issue. They urged all governments, international organisations and the private sector to continue to share information on $\mathrm{Y} 2 \mathrm{~K}$ readiness, to give priority to remediation activities and to engage in contingency planning at all levels. Special attention should be given to the needs of developing countries.

\section{Governance}

Good governance is an essential element in strengthening pluralistic democracy and promoting sustainable development. Ministers welcomed OECD efforts to encourage more effective, efficient and transparent governance structures in Member and non-member countries, inter alia through its work on public sector management, anti-bribery, regulatory reform, corporate governance, ethical principles in public life, local and regional administrations, and ongoing work on indicators of global progress on governance. Ministers requested the OECD to elaborate a proposal for a "good governance" initiative to better share the results of the Organisation's existing work in this field with interested non-member countries, where appropriate in co-operation with other international organisations.
Ministers also requested a progress report on this initiative for their next meeting.

Ministers welcomed and endorsed the OECD Principles of Corporate Governance. These Principles are a major achievement of the OECD. The Principles will assist governments in their efforts to evaluate and improve their countries' frameworks, and will provide guidance for private parties. They will make an important contribution to strengthening the international financial system. Ministers encouraged the implementation and use of the Principles within Member countries, and the exchange of experience among them. Ministers called on the OECD, in co-operation with the World Bank, the IMF and other international organisations, to promote the implementation and use of the Principles in non-member countries. They agreed that the OECD will assess the Principles in light of national experiences and changes in circumstance in due course, possibly in two years.

Ministers welcomed the completion of OECD's reviews of regulatory reform in Japan, Mexico, the Netherlands and the United States. Balanced and comprehensive regulatory reforms can make a major contribution to sustained growth and future prosperity, while promoting high levels of costeffective protection for consumers and citizens. Ministers consider that the findings of these reviews will provide guidance for further reform, both in Member and non-member countries. They look forward to the successful completion of the second round of reviews, of Denmark, Hungary, Korea and Spain, in 2000, and to the extension of the review process to more Member countries. 
The entry into force of the Convention on Combating Bribery of Foreign Public Officials on 15 February is a significant milestone in the international fight against corruption. Ministers, through OECD, will actively monitor the effective implementation of the Convention. They urge all signatory governments which have not yet done so to ratify the Convention and fully implement it, together with the OECD Recommendation on the tax deductibility of bribes, as soon as possible. OECD will promote the objectives of the Convention world-wide and continue to work together with non-members, in co-operation with other international organisations, in the fight against bribery and corruption. Ministers requested the OECD to continue its work to strengthen the fight against corruption, including the examination of the issues of: bribery acts in relation with foreign political parties; advantages promised or given to any person in anticipation of that person becoming a foreign public official; bribery of foreign public officials as a predicate offence for money laundering legislation; the role of foreign subsidiaries and of offshore centres in bribery transactions. Ministers recognised the contributory role of the international trade rules to the fight against corruption and encouraged further analytical work in this regard.

\section{Relations with non-members}

OECD and non-OECD economies increasingly face interdependent challenges and opportunities in the rapidly integrating world. Ministers underlined the need for deepened policy dialogue, and encouraged the discussion under way on the enhancement of OECD's co-operation with nonmembers.
Ministers welcomed the participation of a number of non-member countries in a Special Ministerial Dialogue, which builds on many years of mutually beneficial co-operation with a wide range of nonmembers. This Special Dialogue fostered shared understanding of global policy challenges - the promotion of growth, sustainable development and social cohesion, and how to reap and share the full benefits of trade and investment liberalisation.

The OECD remains open to new members sharing the same values, while being selective and preserving its high standards for membership. Ministers looked forward to the conclusion of the process of accession of the Slovak Republic to the Organisation.

\section{South Eastern Europe}

Ministers discussed the serious situation in South Eastern Europe, focusing in particular on its economic consequences for countries in the region. A successful coherent long-term development strategy will require commitment by the full range of actors involved. They therefore welcomed the international initiative to establish a Stability Pact for the region with the aim of building a democratic, peaceful and economically prosperous South Eastern Europe. In this connection, they noted the mechanism for operational co-ordination set up by the World Bank and the European Commission.

Ministers pledged the OECD's active participation in the efforts of the international community and support to this process, drawing on the Organisation's comparative advantages and substantial experience in assisting transition economies. The OECD can make an important contribution in advis- 
ing the affected states in the region on the development of macroeconomic, structural and social policies, in helping to build the necessary legal and institutional frameworks and in promoting integration into the regional and global economy. The OECD's existing co-operation programmes with countries in the region should be strengthened, and the Organisation should launch, when practicable, programmes with other affected countries.

\section{Development}

Ministers reiterated the importance of the OECD's development partnership strategy and recognised the need to make greater progress in gearing their development co-operation policies to partnership principles and practices. They welcomed the strengthened dialogue with multilateral institutions to improve aid co-ordination and the joint work with the UN and the World Bank on the international development targets. Greater policy coherence is essential to achieve these targets. Ministers noted the report on trade and investment and development and agreed to continue to work together at the OECD to take greater account of the impact of their own policy frameworks on developing countries. The OECD will undertake further analytical work in this area, and report.

Responding to the downward trend of official development assistance levels over recent years, Ministers stressed the importance of maintaining substantial volumes of aid, in particular for the poorest countries, and to improve the quality of such aid. Ministers regretted that the conditions were not yet fulfilled to conclude an agreement on untying aid to least developed countries. However, they noted the progress accomplished in the OECD since 1998 regarding principles and modalities for untying aid and encouraged further efforts to conclude a Recommendation in response to the agreed mandate.

OECD plays an important role in the search for shared growth and prosperity in the global economy. Ministers recognised OECD's reform efforts in recent years and looked to the Organisation to consolidate and build on them. Substantial budgetary reductions have been completed, and Ministers endorsed the goal of financial stability for the Organisation's activities in the coming years. They agreed that a comprehensive solution to the pensions funding issue was also essential if this stability was to be achieved.

The political, economic and social challenges of the next century require informed and actively participating citizens. Ministers recognise their heightened responsibility to ensure transparency and clarity in policy-making, and looked to the Organisation to assist governments in the important task of improving communication and consultation with civil society. 


\section{ECONOMIC AFFAIRS \\ www.oecd.org/eco/eco/}

The Economics Department examines economic and financial developments in OECD countries, and in certain non-member countries. This mission is carried out by the Economic Policy Committee (EPC) and its subsidiary bodies, the Working Group on Short-term Economic Prospects, Working Party $\mathrm{N}^{\circ} 1$ on Macroeconomic and Structural Policy Analysis, and Working Party $\mathrm{N}^{\circ} 3$ on Policies for the Promotion of Better International Payments Equilibrium, as well as the Economic and Development Review Committee (EDRC). The EPC was the first committee created by OECD countries. It groups senior policy advisers who exert significant influence on the action of national governments and central banks.

\section{Macroeconomic evaluation}

Twice a year, the OECD Economic Outlook presents trends and developments in the main macroeconomic variables and makes global forecasts for the coming 18 months. Policy issues relating to OECD Member countries, and to certain non-member economies, are discussed. The short-term forecasts serve as a basis for the economic policy recommendations made by Ministers at their annual Council meeting. Additional special themes addressed by the Economic Outlook in 1999 covered labour market performance, external imbalances, medium-term fiscal issues and financial markets (see below). The major themes for 2000 will in all likelihood include, in particular, growth performance across OECD countries, regulatory reform and structural unemployment.

\section{Economic surveys}

In the context of the surveillance the Economic and Development Review Committee regularly exercises on the economic and policy development in individual Member countries, 21 country examinations were conducted by the Committee in 1999.

As in previous years, increasing attention has been paid during these examinations to the progress achieved in implementing structural reforms in various areas, such as: the labour market, the financial system, health care, trade, competition policy, corporate governance, public enterprises, innovation and technology, etc. At the same time, the following structural themes have been highlighted across the countries under review: tax reform, ageing population and sustainable development. These themes will also dominate the Committee's work in 2000.

\section{Structural features of economies}

Ensuring that economic policy leaders pay sufficient attention to questions of political stability and social cohesion, and to sharing the fruits of economic growth throughout society, has become a top priority of the Organisation. In 1999 the Economic Policy Committee and its Working Parties examined in detail a range of structural policy issues. The main features of these analyses were then published in the Economic Outlook. The principal issues covered were:

- Labour market performance and the OECD Jobs Strategy. Labour market performance has improved in many OECD countries over the 1990s, although 
progress has been uneven, and unemployment remains too high and employment too low in many. Differences in developments across countries were related to progress made in implementing the OECD Jobs Strategy. This suggests that a comprehensive programme of reforms, along the lines of the Strategy, can significantly improve labour market conditions. However, policy-makers must stay the course in implementing reforms - it takes time for their effects to materialise in the labour markets.

- Making work pay. A follow-up to work on labour markets involved an assessment of policy measures to improve the employment and income situation of people with low earnings capacity. Targeted payroll tax cuts and in-work financial support for lowpaid workers have been successful in stimulating employment of the targeted groups and they have often proved to be effective in redistributing income towards those with low pay. However, these policies may also risk weakening work incentives for those already in work. Furthermore, the overall employment effect depends importantly on the structure of earnings and on how "making work pay" policies fit into a comprehensive strategy.

- The size and role of automatic fiscal stabilisers. Components of government budgets affected by the macroeconomic situation ("automatic stabilisers") operate to smooth the business cycle in individual OECD countries. In the 1990s, however, in some countries the need to undertake fiscal consolidation in order to improve public finances has forced governments to take discretionary actions that have reduced, or even offset, the effect of automatic fiscal stabilisers. By preventing sharp economic fluctuations, fiscal stabilisers may raise longterm economic performance. Nonetheless, they should be employed symmetrically over the cycle in order to avoid costly debt accumulation.

- Public debt management. Public debt managers face difficult - and different - challenges in the years to come. For countries like the United States where gross debt is shrinking rapidly, it is an open question whether private-sector securities can serve the same functions in financial markets as the traditionally important government debt market. In the euro area, a reasonable degree of co-operation between independent debt management strategies will help to ensure an efficient euro-area financial market. In Japan, the level of debt is projected to rise rapidly and there is in particular a need to make debt management more efficient, yielding significant budgetary savings.

- Capital flows to emerging market economies. Examining the factors behind the recent financial market crises in these economies, and considering key differences in capital markets institutions and supervision between emerging and mature OECD countries, it was concluded that a sound financial system, including effective regulation, and macroeconomic stability are prerequisites for a successful integration with global capital markets. Currency pegs can sometimes (but not always) be used as a stabilisation tool but they can also involve dangers. While the imposition of capital controls as an emergency measure may yield some short-term benefits, improved crisis management in a multilateral setting would be more appropriate.

- Current-account imbalances. Current accounts of major OECD regions widened in 1999, raising questions about sustainability and the risk of disruptive exchange-rate movements and/or trade tensions. Hence, the forces underlying the widening of OECD 
current-account imbalances in 1999 were analysed. Import contraction in the Asian crisis countries was found to have had a major impact on OECD exports, especially from Japan. In addition, increased current-account imbalances of both Japan and the United States reflect differences in demand trends. The corresponding savings-investment imbalances may persist over the medium term.

- Trends in market openness. Protectionist trade policies, especially on industrial goods, have gradually been scaled back substantially over the past 40 years. Against this background, market openness has increased significantly, although changes have been uneven across sectors and countries. For instance, barriers to trade in agriculture remain pervasive in most OECD countries. In very recent years there are concerns that recourse to some trade policy instruments, such as anti-dumping measures, is being misused. At times, domestic policies ostensibly aimed at other objectives (e.g. health or environmental protection) also restrict market access.

- Cross-country patterns of product market regulation. In co-operation with Member countries, the OECD has assembled a unique database on the regulatory environment in product markets. These data suggest that countries resemble each other in terms of relatively liberal international trade and investment policies, but that domestic regulations still differ across countries in their scope and potential effects on product market competition. As well, there is a tendency for countries having heavy administrative burdens also to have more intrusive economic regulations. Differences across countries have to be seen in context, however. The data suggest that all Member countries are relatively liberal.

- Policy challenges arising from climate change. Most OECD countries have signed the Kyoto Protocol, committing themselves to specific emissions targets of "greenhouse gases" for the period 2008-12. Meeting these commitments will require decisive action across a range of policies. In this context, the international trading of emissions allowances can play an important role in minimising costs. Beyond Kyoto, developing countries have to be brought into the process; resolving equity concerns will clearly be key to achieving agreement. However, even if these policies succeed, some climate change is likely; countries must therefore consider what policy changes would be involved in adapting to it.

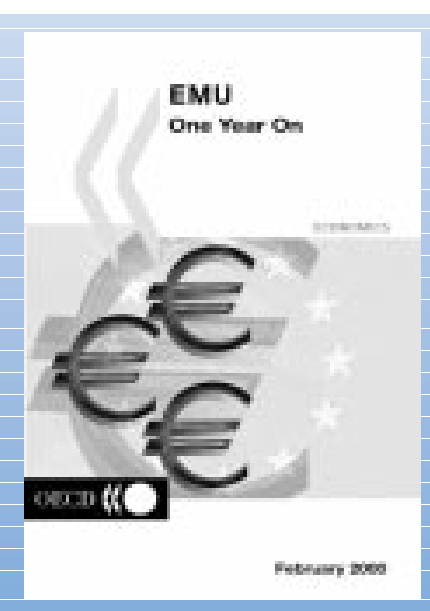

\section{EMU: One Year on}

Europe's single currency was launched at the beginning of 1999 for 11 of the 15 countries of the Union. This study assesses economic developments and policies during the inaugural year of the new regime.

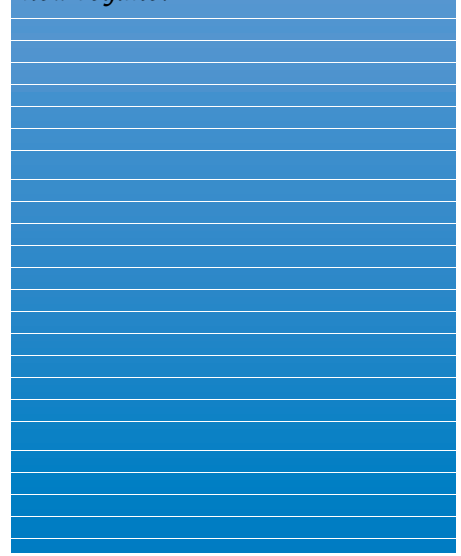




\section{THE OECD GROWTH PROJECT}

At its May 1999 meeting, the OECD Ministerial Council asked the OECD to study the causes of growth disparities across countries, and to identify factors and policies which could strengthen long-term growth performance. In response to this mandate a work programme was prepared which draws on past and ongoing work as well as new activities. A number of Directorates, committees and working parties will be involved across the Organisation.

The main orientations which will guide the work programme are as follows:

- A focus on the causes of economy-wide growth.

- A framework which can, in an integrated and consistent way, account for past growth and recent developments.

- An investigation of the microeconomic sources of growth as an essential complement to the economy-wide perspective.

- An emphasis on those determinants of growth which are amenable to policy actions.

There are three main strands to the analysis which will form the background to the policy orientations of the final report that will be delivered to OECD Ministers in 2001. First, there will be a detailed investigation of recent trends in growth. This entails distinguishing between cyclical and trend developments with a view, not least, to examining the claims that some OECD economies have entered a "new age". It also entails quantifying the contributions to growth that arise from more inputs to production, e.g. more labour and capital, and from increased effectiveness of their use. Among the factors highlighted in this regard will be the influence of technology, including the contributions coming from new information and communications technologies.

Having established a clearer picture of trends in growth, the second main strand of analysis will deal with a crucial issue from a policy perspective: the linkages between aggregate growth, policies and other factors acting. This analysis will investigate both the individual determinants of growth, including the development of human capital, and aim to ensure overall consistency in accounting for economywide growth patterns.

The final strand of analysis will aim to highlight the micro-foundations of growth. Using evidence on developments at the level of individual enterprises, the growth process will be examined with a view to quantifying the contributions to growth from the birth, death and growth of enterprises. Equally, the characteristics associated with survival and growth of enterprises will be examined in order to draw out the implications for policy as regards, for example, entry barriers, the role of a well-educated workforce and RED. A particular emphasis will be put on the characteristics of firms showing very high growth. 


\section{STATISTICS}

www.oecd.org/std/

The Statistics Directorate (STD) provides analysts in the Secretariat, Member countries and the public with comprehensive, comparable and reliable economic statistics. The Directorate also ensures that government agencies, professional researchers and analysts have easy access to all statistical information the OECD publishes. Finally, the Directorate is responsible for co-ordinating statistical work within the Organisation and representation of the OECD with other international statistical agencies.

\section{Short-term economic indicators}

Short-term economic indicators are used by other parts of the Organisation in the research and analysis they perform for Member governments.

Main Economic Indicators (MEI), one of OECD's flagship publications, is produced each month as a printed publication and on CD-ROM. Classified by subject and country, the indicators provide a timely picture of the global economic situation through presentation of an extensive range of short-term economic indicators. In early 2000, the country coverage of MEI was extended to include indicators for ten of the non-member countries within the programme of activities of the Centre for Co-operation with Non-Members (CCNM). The ten countries comprise Bulgaria, China, Estonia, Latvia, Lithuania, Romania, Russian Federation, Slovenia, Slovakia and Ukraine. 1999 also saw the inclusion of an extensive range of short-term indicators for the euro zone. The weekly Hot-File provides a set of the most timely indicators via online connections on the Internet.
Other short-term indicators include Leading Indicators and Business Tendency Surveys (monthly on CD-ROM) which provide early signals of turning points in economic activity; Quarterly Labour Force Statistics (in print and on CD-ROM); Annual Labour Force Statistics; Indicators of Industrial Activity (quarterly in print and on CD-ROM); Industrial Structure Statistics (annually in print and on CDROM). The 1999 Industrial Structure Statistics publication also included for the first time a range of annual structural indicators for the service sector for some Member countries. In 2000 it is planned to release a publication on small and medium-sized enterprises.

The Directorate maintains comprehensive methodological information on sources and definitions, and on how the statistics are compiled. This information is essential for ensuring appropriate use of the data and makes clear the degree of comparability of published data. This methodological information was last published in Main Economic Indicators: Sources and Definitions (July 1997). This publication is being updated for release in 2000. A new publication will be released in 2000 comparing methodologies used by countries included in MEI in the collection and compilation of short-term indicators and, in particular, how these methodologies relate to existing international guidelines and recommendations. The methodological information for the Main Economic Indicators publication is updated monthly on the CD-ROM version. In 1999 a sources and definitions publication was also released for quantitative industrial short-term indicators. All of the methodological information is available on the OECD Internet site. 


\section{Non-members}

The main focus of work with non-members changed in 1999 from transition countries to a broader group of non-member countries of immediate interest to the Organisation because of their impact on the world economy.

A new monthly publication of short-term economic statistics for non-member countries was launched via the Internet. Country coverage was extended to Russia and China and arrangements were completed to include monthly statistics for non-members in the STD flagship publication Main Economic Indicators (see above).

Purchasing power parities (PPPs) are specially calculated exchange rates that eliminate differences in the price levels of different countries. They are needed to compare living standards between countries. PPP calculations for 1996 were completed for the New Independent States (NIS) of the former Soviet Union and results were released comparing living standards in these countries with those in OECD Member countries and in the countries of Central and Eastern Europe.

Work with Ukraine and Russia on measuring the hidden economy continued. A team of international experts is being co-ordinated by STD to produce a manual on the Measurement of the Non-Observed Economy. This will draw on the practical experience accumulated by STD in the transition countries and on the methods developed in OECD countries to improve the coverage of basic economic statistics and national accounts. A detailed outline has been agreed and first drafts of several chapters have now been produced. Publication is scheduled for the second half of 2000.

Agreement was reached on the participation of China in the PPP comparisons for 2000. Successful completion of this programme will make it possible, for the first time, to assess accurately the size of China in the world economy. Work progressed satisfactorily on a report on the sources and methods used to compile national accounts in China; this will be published early in 2000. A seminar on cyclical analysis was held in Beijing and training was also provided in Paris. A report on this work was prepared and will be issued in early 2000 as a joint publication together with the National Bureau of Statistics of China.

Business tendency (or "opinion") surveys have proved a particularly valuable source of information on shortterm economic developments in the transition economies. In most of these countries, the coverage and timeliness of traditional quantitative statistics has deteriorated in recent years. In Russia, a further seminar was held, with the results to be issued in early 2000 as a joint publication of the OECD, the Russian Goskomstat and the Centre for Economic Analysis. A workshop on business tendency surveys was also held in Manila for countries of the ASEAN group. The main focus of this workshop was to encourage countries of the region to adopt a standard set of questions to enhance international comparability; future workshops will concentrate on the use of survey results for cyclical analysis and short-term economic monitoring. This programme is being organised jointly with the Asian Development Bank.

As part of the OECD's Baltic Programme a project post was created with the aim of working with the Baltic countries to develop their macroeconomic statistics in areas that the countries view as priorities. As EU candidate countries, they already have extensive programmes of technical co-operation with Eurostat, and STD works closely with Eurostat to co-ordinate work programmes. The main focus is the development of quarterly national accounts, for which a workshop was held in July 1999, and a follow-up workshop will be 
held in July 2000. Work has started on a publication describing the basic data sources and methods used by each of the Baltic countries to compile their quarterly national accounts, and publication is scheduled for the second half of 2000 .

Staff presented papers at international meetings on the calculation of purchasing power parities and methods of linking results for different regions, on theoretical and practical aspects of capital stock statistics, on business tendency surveys and the use of survey results for cyclical analysis and on methods of estimating economic activities in the "non-observed economy". Staff members also participated in international task forces on price and volume measures in the national accounts, on standardisation of consumer and producer price indices and on statistics of international trade in services.

\section{Structural statistics}

The Directorate continued its programme of regular publications for OECD Member countries on annual and quarterly national accounts, annual and monthly foreign trade, annual economic accounts for agriculture, purchasing power parities and services. This work also requires involvement in the development of new statistical systems and classifications, in outreach activities and organising meetings of national experts. The highlights are noted below.

The OECD developed the first international system of national accounts in the early 1950s and continues to play a major role in this area. Three functional classifications, which form part of the 1993 System of National Accounts (SNA), were approved by the United Nations Statistical Commission at its meeting in March 1999. These relate to outlays by the government, household and non-profit sectors. A draft of the changes required to the 1993 SNA as a result of these new classifications was circulated to national statistical offices around the world for comment prior to submission to the 2000 meeting of the United Nations Statistical Commission for approval. A glossary that provides precise definitions of about 600 technical terms used in the 1993 SNA will be published in 2000.

As convenor of the UN Task Force on Statistics of International Trade in Services, OECD plays a major role in designing a manual on this topic. The manual will help Member countries to monitor the implementation of the General Agreement on Trade in Services (GATS) and to assess the direction and pace of globalisation in the production of services. Development of this manual is being closely co-ordinated with related work being undertaken by other parts of the Organisation on foreign direct investment and activities of foreign affiliates. A draft manual was presented to a Task Force meeting in July 1999; a revised version was prepared as a result of the comments made at that meeting and is now subject to a world-wide review. The manual will be revised following discussions at a meeting in February 2000 with a view to being submitted to the United Nations Statistical Commission for consideration at its meeting in early 2001.

Close collaboration with Eurostat continues. Staff members participated in three task forces examining methods for measuring the underlying prices required to calculate volumes of expenditure on computers, construction and large items of capital equipment, such as ships and aircraft. A joint publication of statistics of international service transactions was produced in May and a joint meeting of trade in services experts was held in July.

The first OECD meeting on international trade statistics was held in 1999. It discussed a range of issues 
including the consistency of international trade data, minimising the reporting burden on countries by international organisations sharing data and the problems caused by countries having different reporting thresholds for international trade. The meeting was considered to be very successful and a follow-up meeting is planned for late 2000.

The annual OECD national accounts meeting was held in September 1999. It concentrated on issues related to the implementation of the 1993 System of National Accounts (SNA) and innovative ways in which countries had overcome implementation problems. During 1999, most OECD countries switched from the 1968 version to the 1993 version of the SNA as the basis for compiling both their annual and quarterly national accounts. A number of problems have arisen as a result. The main ones are: some countries are producing very short time series on the new basis (only 4 years in some cases); the data for a number of countries are less detailed than those previously available; the constant price estimates produced by some countries are of the chain volume type while those for others are the more traditional fixed-base volume estimates which are not directly comparable with chain volume estimates. Moreover, the changeover dates differ from one country to another (or even from one part of the accounts to another within a country) which has led to comparability problems because of 1993 SNA-based data being stored in the OECD national accounts databases for some countries and 1968 SNA-based data for others. It is likely to take two or three years before these problems are resolved.

The publication showing the detailed results of the 1996 round of the Purchasing Power Parity (PPP) Programme was finalised in 1999. It contains a much more detailed description of the issues associated with compiling PPPs than was previously the case. A special PPP site was also set up on the Internet to provide details of ongoing work on PPPs. The address of the site is http://www.oecd.org/std/nahome.htm. Work on the 1999 PPP round continued, with OECD staff visiting the national statistical offices in Australia and New Zealand and with a meeting in Washington with representatives of the USA, Canada and Mexico.

Work on Economic Accounts for Agriculture concentrated on the preparations for the experts meeting held in February 2000, at which the proposed new OECD framework was discussed. Preliminary work for this meeting was largely undertaken by means of an electronic discussion group. The second main strand of activity related to the preparation of, and participation in, international meetings on agricultural statistics, organised within the framework of the Inter-Secretariat Working group. Following an invitation from the FAO, a seminar on agricultural accounts was organised by a staff member in China.

Staff presented papers on: measurement of the real output of non-market services; what is required to implement the 1993 System of National Accounts; measuring inventories; methods used to collect prices of services provided to enterprises; projecting PPPs to form time series; and alternative methods of presenting services data in the national accounts. 


\title{
THE COMMITTEE,
}

\section{AN ESSENTIAL PART OF THE OECD MACHINERY}

\author{
The example of the Economic and Development Review Committee
}

Since its creation in 1961, the Economic and Development Review Committee (EDRC) has been at the core of the so-called "peer pressure" mechanism which is the essence of multilateral surveillance within the OECD. The major role of this Committee is indeed to examine the economic trends and policies in individual Member countries of the Organisation, with the view to assisting the broad performance of their economy and issuing policy recommendations to improve that performance.

In recent years, such examinations were extended to selected non-member countries from Central and Eastern Europe, in order to monitor their transformation to market-oriented economies. Over the 1990s, a number of countries (Mexico, Korea, Czech Republic, Hungary, Poland) were also reviewed by the EDRC, prior to their accession to the OECD. Reviews are also taking place on Slovakia, which may become a new OECD Member, and on Russia, with which the Organisation has a special programme.

The Committee's examinations of each OECD economy are conducted on a regular basis, currently every 12 to 18 months. They are attended by permanent delegates of Member countries, sometimes assisted by experts from capitals. For the countries examined, a high-level and multi-institutional representation is the norm, although the size and com- position of delegations vary from one country to another. To help the Committee carry out its work effectively, two examining countries are designated for each review.

EDRC country reviews are based on in-depth surveys prepared by the OECD Secretariat, covering both macroeconomic and structural issues. The macroeconomic material of the surveys includes an analysis of the recent economic developments and prospects as well as an appraisal of the monetary and fiscal policy stance against announced government objectives. For some years, the central issues of interest to the Committee in this regard have been the way that monetary policies are conducted to achieve price stability in an environment of financial liberalisation and their effects on the real economy. Short-term fiscal policy analysis has been concerned with the pace of fiscal consolidation, focusing on its impact on economic activity and interest rates. Now that a growing number of countries have managed to bring down budget deficits or even achieved surpluses, the question of appropriate medium- and long-term paths for government indebtedness, to face the consequences of ageing population, has become more pressing.

The surveys also review developments across a broad range of structural policies and generally 
include a detailed analysis of a specific structural topic. Among the issues which have been dealt with by the Committee in the recent period is the individual countries' progress in implementing the OECD Jobs Strategy to improve the functioning of their labour market. Other topics include financial sector reform, corporate governance, education policies as well as, more recently, health and pension systems, tax reform and sustainable development.

As such, the contents of the surveys aim at:

- promoting better understanding of the country's economic situation and key challenges facing the authorities; and

- pointing towards ways of improving the country's overall economic performance.

Following country examinations, draft surveys are revised by the Secretariat in the light of comments and recommendations made by the Committee, as summarised by its Chairman. Amended versions are then officially approved by the Committee for publication under its own responsibility. The information thus delivered to the general public contributes to the enrichment of the policy debate both domestically, in the country under review and internationally.

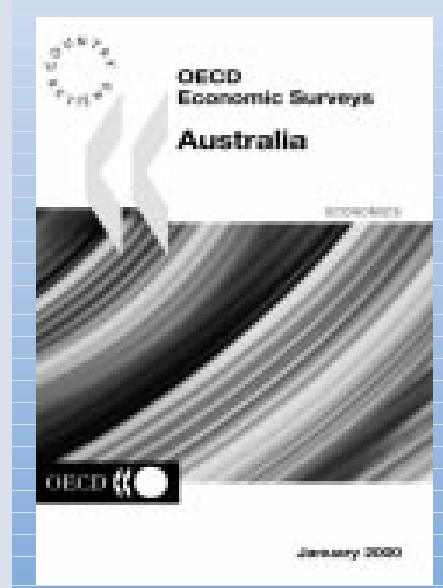

OECD Economic Surveys:

Australia

The OECD produces annual reviews of Member countries' economies and selected nonmember countries. Each issue provides a solid analysis of developments in the subject country, special reports on topics of current interest, and extensive statistical information. 


\section{TRADE}

www.oecd.org/ech/

The work of the Trade Directorate supports a strong, open and rules-based multilateral trading system. Its objective is to ensure that the liberalisation flowing from the Uruguay Round moves ahead smoothly and that the multilateral trading system, centred on the World Trade Organization (WTO), functions effectively and is equipped to address major trade policy issues. The OECD Trade Committee, which is made up of senior trade policy-makers in OECD Member countries, guides and animates this work. It is assisted in this task by its Working Party, composed of representatives from the Permanent Delegations to OECD.

Over the past 50 years, trade has been the primary engine of world growth and contributed to prosperity, development and higher living standards for all countries. During this same period, world trade has increased by a factor of 17 , world output has quadrupled and per capita world income has doubled. Since 1947, eight rounds of multilateral trade negotiations have each advanced the agenda of free trade. It had been widely expected that WTO members would agree at their Third Ministerial meeting in Seattle at the end of November 1999 to embark upon a ninth round. However, the "millennium" round did not materialise in the timeframe expected.

While efforts focus on getting the negotiating process on track, it will be even more important for the Trade Committee to move firmly ahead with its analytical work supporting and complementing further liberalisation. There are new challenges facing the multilateral trading system which will have to be dealt with. The interlinkages between trade and other areas of policy will continue to be an important element of the work. Also it is envisaged that the Trade Committee will direct even more attention to the developing country dimension of trade liberalisation.

At the conclusion of the Uruguay Round in 1994, WTO members realised that further improvements would be needed in the trading system, and they committed to negotiations on agriculture and services to begin in 2000. As market access issues will figure at the core of an eventual new round, the trade programme has been examining market access issues across a range of areas and will continue to do so in the foreseeable term.

\section{Market access}

\section{Services}

One of these areas is services. In 1999 a highly successful OECD meeting of services experts helped maintain the momentum and focus of the work that began two years earlier. Further inventories of barriers to trade in the retail sector and air cargo were added to the growing body of sectoral knowledge that already included financial information services, environmental services, and distribution services. While the work had followed mainly a sectoral approach, it diversified in 1999, with an in-depth analysis of the concept of using qualitative "formulas" in GATS (General Agreement on Trade in Services) negotiations. It is envisaged that the "formulas" could consist of model schedules and measuresbased commitments for each of the four GATS "modes" of service supply. This work, which could be of particular interest to developing countries, was shared with a 
number of non-member countries at an Emerging Market Economies Forum (EMEF) workshop in September and was commended for the support it will provide to work at the WTO.

Looking ahead, analysis will be further developed on ways to improve the transparency of services traderelated regulation, and on the utility of the application across service sectors of the pro-competitive regulatory principles of the WTO Basic Telecommunications Agreement and its reference paper. Further sectoral inventories are envisaged as well, and will be drawn upon in building up a consolidated list of cross-sector barriers to trade in services. The directions and focus of further work will be examined at a second meeting of services experts on 25-26 May 2000.

\section{Electronic commerce}

Projects on electronic commerce examined existing GATS-specific commitments for Mode 1 (cross-border supply) and Mode 2 (consumption of services abroad) and surveyed unilateral liberalisation to promote electronic commerce. The study on GATS-specific commitments found that commitments to liberalisation are lacking or narrow in most sectors. The study on unilateral liberalisation demonstrates the importance of telecommunications reform and reductions in tariffs on equipment. The results of these projects were made available as background material to participants at the Paris Forum on Electronic Commerce at OECD in October 1999. In the coming year, efforts will focus on examining a set of case studies of the online delivery process for digital information "products" that can be delivered both in "packaged" form (attached to physical carrier media) and over electronic networks. This work aims to provide an empirical basis for assessment of the main characteristics of online delivery compared with "packaged" delivery of digital information.

\section{Tariffs}

The year 1999 marked the culmination of the Trade Committee's innovative work on remaining tariffs in OECD countries and in major non-OECD countries that began early in 1998. A synthesis report of the detailed work and analysis was published early in autumn of 1999 under the title Post-Uruguay Round Tariff Regimes: Achievements and Outlook. This work provides trade negotiators with an important tool that will help them formulate their negotiating objectives and strategies in the area of tariffs. It also provides policy analysts with key data that are necessary to define negotiating scenarios and to impute the corresponding impact on trade, employment and growth.

Given this project's unique contribution to future multilateral trade negotiations as well as its usefulness as an analytical tool, the OECD is in the process of making the tariff data that were collected, verified and analysed throughout the project, available on CD-ROM. The OECD plans a wider distribution of the product outside its membership. An alpha version of the CDROM has been tested in 1999, and modules allowing users to define and compute the welfare impact of different simulation scenarios will be added in 2000 .

\section{Non-tariff barriers (NTB)}

Reflections continued on how most effectively to identify and address the effects of various non-tariff measures. The work has involved advancing the concept of non-tariff barriers to cover both border and behindthe-border measures. During 1999, work focused on developing a new generic typology of NTBs that was considered in terms of two sectors - automobiles and telecommunications equipment. In addition, the concept of NTBs has been expanded to cover both explicit policies that impede trade, as well as the way policies are implemented (for example, the transparency and 
predictability of policies). Work is being pursued to improve available data on the existence of NTBs. A review was also undertaken of current issues in the field of trade facilitation. At a workshop in September with non-OECD countries on barriers to trade in goods and services in the post-Uruguay Round context, a portion of the discussion was devoted to outstanding issues on NTBs.

\section{Intellectual property}

As a contribution to preparations for the WTO review of the Trade-Related Intellectual Property Rights Agreement (TRIPS), the Trade Committee completed an overview of existing practices in OECD countries with respect to patents and plant variety protection systems. The aim of the overview was to enhance transparency and promote a better understanding of the nature of intellectual property protection of biotechnology inventions in OECD countries, as well as to identify commonalties and divergences. The overview is available on the Trade pages of the OECD Internet site.

\section{Government procurement}

Research aiming to provide better data on the size of government procurement markets in OECD countries got under way in 1999. This project, which will continue in 2000, will provide a basis for assessing the economic gains that countries could derive from liberal government procurement policies. Because governments at federal and sub-federal levels and state-owned enterprises are big purchasers of goods and services, these markets represent significant opportunities for international trade. The project will use national accounts statistical data to estimate the size of the markets.

\section{Regulatory reform}

The Trade Committee continued in 1999 to participate in OECD's multidisciplinary project reviewing individual countries' experience with regulatory reform. In 1999, it assessed the experience of Denmark, Hungary, Korea and Spain, focusing on the application of the six principles of efficient regulation designed to help maintain open markets. These are transparency, non-discrimination, avoidance of unnecessary trade restrictiveness, international harmonised measures, recognition of other countries' measures and application of competition principles. The "market openness" chapters for the reviews of these four countries are combined with chapters from other parts of the OECD and will be published in 2000 .

Related work is also under way to help strengthen approaches to the development and implementation of international standards so as to contribute to reducing or avoiding technical barriers to trade. The project has so far drawn upon an inventory of international standardising activities, followed up by sectoral case studies that aim to deepen understanding of the WTO Technical Barriers to Trade Agreement and of practical ways for ensuring its effective implementation. In parallel, a study has assessed the costs to business arising from having to meet different regulatory requirements in different countries. When firms are engaged in international trade, domestic regulations may necessitate different product designs for different markets or repetitive conformity assessment procedures.

The different elements of this project will be addressed at a special meeting on international standards and conformity assessment planned for March 2000. The results of this meeting will be presented in a broader outreach context by the Trade Committee in an EMEF workshop toward the end of 2000 . 


\section{Codes of corporate conduct}

With the goal of injecting more transparency into a rather new area of corporate activity whose economic importance is not well understood, the Trade Committee has undertaken an inventory of existing voluntary codes of corporate conduct, based on indications from Member governments. The inventory surveys codes across a wide spectrum of areas that include environmental stewardship, fair employment, fair business practices, observance of the rule of law, respect for human rights, corporate citizenship and new technologies. An analytical overview of the inventory is available on the Trade pages of the OECD Internet site. Based on preliminary research in this area and complementing work on codes undertaken by other OECD Directorates, the Trade Directorate has begun to analyse in more detail how codes operate, how significant code activity is in individual industries and how codes affect companies' global trade and investment activities.

\section{Policy interrelationships}

The links between trade policy and other policy domains are important dimensions in market openness. Links between trade and environment, trade and competition, trade and labour standards, and trade and agriculture have been the focus of work in 1999 and will continue in 2000.

\section{Trade and environment}

The Joint Working Party on Trade and Environment (JWP) held a successful workshop in October 1999 on Methodologies for Assessing Environmental Effects of Trade Liberalisation. It brought together practitioners of past and current reviews, academic experts, NGOs and developing country representatives to share state of the art assessment techniques. The workshop pro- ceedings were published in February 2000. The JWP also drew together in a publication, Trade Measures in Multilateral Environmental Agreements (MEAs), the fruits of extensive work on the use of trade measures in three MEAs, drawing lessons in one of the prime areas of concern for the environment/trade rules interface. Looking ahead the JWP will continue with its examination of the environmental effects of trade liberalisation, with a particular focus on environmental goods and services, fossil fuels and agriculture. In the course of all this work, the Secretariat will maintain its close links with the WTO, ensuring continuation of the practice whereby the WTO Committee on Trade and the Environment is fully briefed on the work of OECD's Joint Working Party.

\section{Trade and competition}

Important elements of the work of the OECD Joint Group on Trade and Competition in 1999 were encapsulated in two publications. The first, Trade and Competition Policies for Tomorrow: Working Papers of the Joint Group on Trade and Competition, draws together five papers prepared over an extended period by the Joint Group. These examine ways of increasing the coherence between trade and competition policy disciplines and issues arising at the interface of these two policy areas. The second publication, Trade and Competition Policies: Exploring the Ways Forward, presents the proceedings of an EMEF Conference on Trade and Competition held in Paris in June 1999. The Conference helped to extend the discussion of the Joint Group's work to representatives of 30 non-OECD emerging countries, business, trade unions and NGOs. The Conference demonstrated how diverse the issues and positions are, not only among countries but also between trade and competition authorities as well as between governments and public stakeholders. A key element of the Joint Group's work, which will extend into its activities 
in 2000 , is the identification of various options for managing the interface of trade and competition policy, ranging over convergence of competition laws and policies, bilateral and regional co-operation and multilateral rules.

\section{Trade and labour standards}

Mindful that the 1996 OECD report Trade, Employment and Labour Standards: A Study of Core Workers Rights and International Trade had provided impetus for the ILO's 1998 Declaration on Fundamental Principles and Rights at Work, and given the growing attention which the trade and labour issue is receiving, the Trade Committee in 1999 commissioned an update of the 1996 study. The update, which will be a focus of the Trade Committee's work in 2000, will review factual developments and contributions to the literature since 1996.

\section{Trade and agriculture}

The Joint Working Party of the Committee for Agriculture and the Trade Committee has launched a programme of work following up the OECD Workshop on Emerging Trade Issues held in autumn 1998 which complements resumption of WTO multilateral trade negotiations on agricultural products. This work will analyse current consumer and taxpayer support for agriculture; evaluate the Uruguay Round Agreement on Agriculture as well as scenarios for further liberalisation; and identify minimally trade-distorting ways through which nontrade concerns and public policy interests can be pursued.

\section{Relations with civil society}

Although the Trade Committee has maintained relations with business and labour through BIAC and TUAC over the years, efforts deepened in 1999 to promote a wider discussion and further policy openness. In two successive Trade Committee meetings, delegates explored ways and means of improving communication and strengthening relations with civil society. Then, in conjunction with its October meeting, the Committee held a day-long informal consultation with nongovernmental organisations to discuss preparations for and issues relating to further liberalisation. Groups representing business, labour, consumer, developmental and environmental groups participated.

\section{Non-member countries and the multilateral trading system}

The Trade Committee, mindful of the important role non-OECD economies play in shaping the multilateral trading system and of its systematic objective of ensuring the smooth integration of these economies into the international system, initiated work on the benefits of multilateral trade liberalisation for non-OECD countries. An important contribution was the publication early in November 1999 of the Committee's report on Non-OECD Countries and Multilateral Trade Liberalisation. The publication presents a qualitative assessment of the benefits to non-OECD economies from enhanced rules and disciplines in the context of the WTO, and a quantitative assessment of potential gains to these from further cuts in protection. In 2000, the Committee plans to deepen its understanding of trade issues of particular importance to non-members.

In order to foster consensus-building in trade policy and provide support for its reform, the Trade Committee continued its dialogue with representatives of selected developing and transition economies through meetings and workshops. Argentina, Brazil, Chile, the Slovak Republic, Hong Kong, China, and Singapore also participate as observers in the Trade Committee and its Working Party. In 1999 two workshops were 
organised with the participation of non-members in the context of the EMEF. The first, in June, tackled issues related to the interface between trade and competition policies. (See section on trade and competition above.) In the second workshop, participants discussed market access issues in the post-Uruguay Round trading environment. Besides OECD Member countries, there were participants from 20 nonmember countries, academia, trade unions and business. They reviewed progress that has been achieved in dismantling tariffs and non-tariff barriers, barriers to trade in services, and those that impinge on trade in environmental goods and services. Participants also exchanged views on how best to continue the drive towards further trade liberalisation.

In the dialogue with trade representatives from transition countries, issues of interest to all transition countries are addressed, in particular market access questions and possible problems of these countries in implementing multilateral trade disciplines. An additional objective is to stimulate a constructive exchange of views on sound trade policy and the experience with the trade liberalisation process, in particular between successful reformers, including those which acceded recently to the WTO, and other transition countries. Specific market access problems were discussed in the presence of high-level trade officials from Ukraine and Romania. Regional co-operation among the NIS continued to be analysed and discussed in order to improve its transparency and assess its implications from the WTO perspective. The dialogue with Russia aims at improving the transparency and predictability of its trade policy and contributes to its deeper understanding and application of multilateral trade disciplines. It focuses on selected critical areas, such as the interface between the central and sub-national levels of govern- ment in the country's trade policy (discussed at a round table in Novgorod in March) and trade in services.

\section{Trade and export credits}

Last year saw the successful implementation of the Knaepen Package on Guiding Principles for Setting Premium, the latest in a line of agreements concluded by the Participants to the Arrangement on Guidelines for Officially Supported Export Credits, now in its 21 st year. The Knaepen Package establishes, for the first time at a multilateral level, detailed minimum riskrelated premiums for official support with the aim of eliminating subsidies and trade distortions.

Also in 1999, the Participants continued negotiations for an Understanding on Agricultural Products, presently excluded from the Arrangement, with a view to concluding this before the 2000 OECD Ministerial Meeting.

The OECD Working Party on Export Credits and Credit Guarantees made significant progress in 1999 on the priority issue of environment by concluding an agreement on Environmental Information Exchange for large projects in environmentally sensitive sectors. The Working Party also renewed the agreement to an information exchange on productive expenditure to encourage the direction of official export credit support in Highly Indebted Poor Countries towards economically and socially worthwhile projects.

The export credit priorities for the year 2000 are agriculture and environment in respect of which OECD Ministers have mandated urgent work before their 2000 Ministerial Meeting: the Participants to conclude the Understanding on Agricultural Products, and the Working Party to strengthen common approaches on the Environment. 
Also in 2000, the Participants will examine further a range of financing issues related to the Arrangement. This includes market windows (institutions or programmes which, while related to government, may not currently follow all the provisions of the Arrangement) and the interest rate regime. Additionally, the Participants are committed to working with the OECD Development Assistance Committee's Working Party on Financial Aspects of Development Assistance on the untying of official development assistance.

The Working Party on Export Credits and Credit Guarantees will continue to keep on its agenda the issue of monitoring the implementation of the OECD Convention on Bribery in relation to export credit activities.

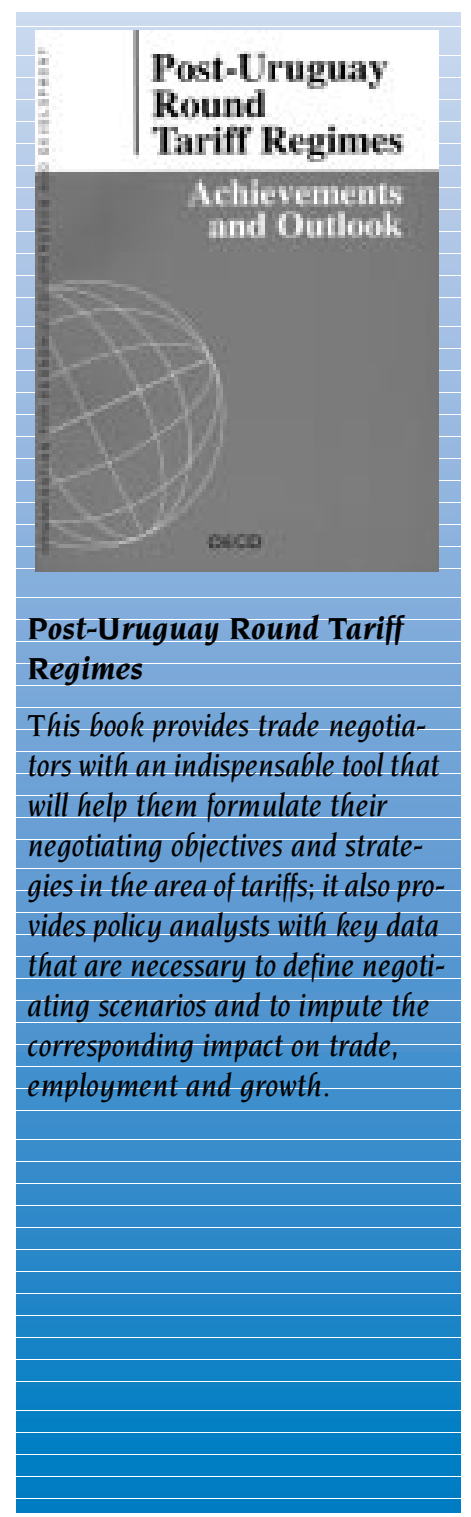




\section{FINANCIAL, FISCAL AND ENTERPRISE AFFAIRS

\author{
www.oecd.org/daf/
}

Promoting the efficient functioning of markets and enterprises in a globalising economy are the prime objectives of the committees in the Directorate for Financial, Fiscal and Enterprise Affairs (DAF). The Directorate is therefore encouraging policy convergence in the areas of competition, taxation, financial markets, international investment and trade in services. New emphasis is being put on corporate affairs policies to facilitate the efficient entry, functioning and exit of enterprises.

In developing frameworks for the rules of the game in each of these areas, the typical instruments employed are benchmarking, establishing best practices and developing policy guidelines. Committees are also increasingly involving non-members in their activities, expanding an earlier focus on Eastern and Central Europe to encompass both Asia and Latin America. Special attention is given to the regeneration of South Eastern Europe in the framework of the Stability Pact. Dialogue with civil society is becoming a regular feature of the analysis of and recommendation for governmental policies.

\section{International investment and multinational enterprises}

A far-reaching review of the OECD Guidelines for Multinational Enterprises dominated activities in 1999. The Guidelines are recommendations by OECD governments and three non-members (Argentina, Brazil and Chile) to help ensure that multinational enterprises (MNEs) act in harmony with the policies of the coun- tries in which they operate and with societal expectations, thus strengthening the basis of mutual confidence between MNEs and host governments. The Guidelines form part of a package of non-binding OECD investment rules which balance the commitment of governments to provide a favourable investment climate with an expression of expectations of responsible corporate behaviour. The Guidelines review is due to be completed by the time of the June 2000 annual meeting of OECD Ministers.

Major conferences were held in 1999, including a conference on foreign direct investment (FDI) and the environment and another on FDI, development and corporate responsibility. In addition, several informal consultations with business, labour and non-governmental organisations were held in the course of the year, particularly with respect to the Guidelines. These conferences and consultations are part of a broader effort to foster greater dialogue with non-members and with civil society. The Internet has also become an important vehicle for promoting this dialogue.

Analytical work advanced on the interface between non-discriminatory investment policies and initiatives in other areas, notably with respect to environmental management and social policies. Fact-finding on codes of corporate conduct was undertaken to support the Guidelines review and to promote a better understanding of corporate responsibility initiatives by businesses.

Several prominent non-members became more closely involved in the OECD's investment activities. 
China signed a memorandum of understanding for cooperation on investment matters, and the Russian Federation was involved in several OECD investment events. Analytical studies were made on investment policies in the Baltic Region and in South-East Asia. The latter resulted in a major publication on Foreign Direct Investment and Recovery in South-East Asia. The investment studies of the three Baltic countries will be published in 2000 .

National policy reviews have traditionally been used to promote the progressive liberalisation of capital movements, FDI and trade in services. Korea, Mexico and Poland were all reviewed in 1999 and a study of Hungary's FDI policies was prepared for publication. Horizontal, issue-oriented studies addressed crossborder trade in professional services and restrictions on the activities of foreign bank branches.

\section{Financial affairs}

The Committee on Financial Markets (CMF) exercises surveillance over developments, reform measures and changes in structural and regulatory conditions in financial markets. It aims, inter alia, to promote international trade in financial services, to foster integration of non-member countries into the global financial system and to improve financial statistics.

In 1999, the CMF concentrated on monitoring of structural changes in financial markets. In addition, the Committee discussed major structural issues, including the implications for financial markets of hedge funds and other highly leveraged investment operations, cross-border trade in financial services, and mergers and acquisitions in the financial services industry. The Working Party on Debt Management focused on structural changes in debt management and government securities markets. The work pro- gramme of the CMF for 1999-2000 includes the future prospects for national financial markets, corporate governance and mutual funds, financial contagion and the monitoring of financial markets with a view to identifying structural trends and evaluation of regulatory reform issues.

The Insurance Committee monitors and surveys structural changes and reform measures in insurance markets and private pensions markets. The Committee created a Working Party on Private Pensions, which is focusing on policy analysis and recommendations in the field of private pensions, in particular their regulatory systems. Agreements were reached in the Committee on principles for investment regulation by insurance companies and pension funds and on liberalisation of investment portfolio by insurance companies and pension funds. Key activities for the Insurance Committee will be private pensions (financial security, adequacy, corporate governance), private health insurance, the revision of the insurance provision of the OECD Codes, regulation of investment and financial convergence. The Committee will also develop the framework for an agreement on exchange of information on reinsurance.

A number of key publications appeared in 1999, including Liberalisation of International Insurance Operations, Glossary of Insurance Policy Terms, and Insurance Regulation and Supervision in Asia. The flagship publication Financial Market Trends continued to orient its editorial policy so as to capitalise on the comparative advantage of OECD in this field. Major articles covered the euro and financial markets, financial market implications of budgetary surpluses, highly leveraged investors, trends in securitisation, the development of fixed-income securities markets in emerging economies. 
The Working Party on Financial Statistics mobilises a vast network of experts dealing with a wide range of methodological and conceptual issues involved in producing harmonised financial statistics. Ongoing statistical work centres on foreign direct investment, national financial accounts, institutional investors, bank profitability and privatisation. In 1999 two new statistical exercises were under development addressing funded pension schemes and government debt. In 1999, the Secretariat finalised a major survey jointly with IMF on the methodological issues of foreign direct investment, published as the Report on the Survey of Implementation of Methodological Standards for Direct Investment. The following annual publications were produced: International Direct Investment Statistics Yearbook; Financial Accounts of OECD Countries; Bank Profitability - Financial Statements of Banks; Institutional Investors Statistical Yearbook.

Major outreach activities were carried out in the fields of private pensions, financial statistics, institutional investors, securities market development, public debt management and insurance. Technical co-operation programmes on foreign direct investment statistics were conducted with the Baltic countries and China.

\section{Corporate affairs}

Corporate affairs policies aim to provide an institutional, legislative and regulatory framework that facilitates the efficient entry, functioning and exit of commercial firms in the economy. Corporate governance, privatisation, and enterprise reform are therefore the three pillars of OECD' s work in this area.

Corporate governance is the central component of the corporate affairs policy menu. When the OECD Principles were adopted in 1999, the Organisation received a mandate to promote global dialogue in co-operation with the World Bank. This took shape with the signature of a wide-ranging co-operation memorandum in June 1999, which included the establishment of regional policy dialogue Round Tables for Asia (in March 1999 in Seoul) and Russia (in June 1999 in Moscow). A Round Table for Latin America will be launched in early 2000. The Round Tables provide a framework for periodic dialogue among regional leaders from the public and private sectors. The OECD and the World Bank also launched a Global Corporate Governance Forum and a senior Private Sector Advisory Group to promote reform, co-ordinate reform efforts and raise resources to this effect at a global level. Senior experts meetings on the OECD Principles also took place in Greece and the Czech Republic as well as in Vilnius (for the Baltic countries) and Istanbul (for the New Independent States).

Privatisation and the sound management of stateowned assets are essential tools for structural adjustment, the development of capital markets and the promotion of better corporate governance. The OECD Privatisation Network of senior officials from Member countries, established in 1995, provides the platform for an ongoing exchange of experience among senior Member country government officials. The OECD Advisory Group (AGP) brings members of the Network together with senior policy-makers from emerging economies and representatives of the private sector. The annual Network and AGP meetings in September 1999 discussed Privatisation, Capital Markets and Pension Reforms as well as recent trends.

Following the crisis in 1997-98, investors and policymakers realised the importance of a sound insolvency framework for the establishment of financial discipline and the effective reallocation of assets in the economy. Insolvency reform in Asia was the topic of 
an OECD study presented at a December 1998 meeting in Sydney organised in co-operation with the World Bank, APEC and the Australian Treasury. Finally, the OECD played a key part in bringing together the major private sector standard setters and professional associations from Russia and the New Independent States in the area of financial disclosure and accounting with the aim of improving transparency in financial markets and facilitating investment in these economies.

\section{Bribery in international business transactions}

On 15 February 1999, the OECD Convention on Combating Bribery of Foreign Public Officials in International Business Transactions entered into force. It represents a landmark in international co-operation to fight bribery and corruption. The Convention sends a clear signal that OECD countries and the nonmembers associated with the Convention will act in concert to halt the flow of bribes to foreign public officials in international business transactions. By yearend, eighteen countries (16 OECD and 2 non-OECD countries) had deposited instruments of ratification with the OECD Secretary-General (see list below).

Signing the Convention obliges countries to criminalise the bribery of foreign public officials, and it also commits them to making broader efforts to fight corruption through adherence to the 1997 OECD Revised Recommendation on Combating Bribery in International Business Transactions. Countries are also taking steps to comply with a 1996 Recommendation that bribes to foreign public officials not be tax deductible. Immediately following the entry into force of the Convention, the Working Group on Bribery in International Business Transactions began assessing the effectiveness of national legislation adopted by countries to implement the obligations of the Convention and measures taken to comply with the Recommendations. Sixteen countries had been evaluated by December 1999. The results of these examinations, together with the evaluations of all signatories to the Convention, will be presented to OECD Ministers in June 2000.

In 1999, the Working Group on Bribery also began examining bribery acts in several new domains. Included are relations with foreign political parties, advantages promised or given in anticipation of a person becoming a foreign public official, bribery of foreign public officials as a predicate offence for money laundering legislation, the role of foreign subsidiaries in bribery transactions and the role of offshore centres in bribery transactions.

Sharing information on developments and initiatives taken by countries, international organisations, and civil society can be an effective tool in combating corruption. In 1999, several regional events were organised in Latin America, Asia and in transition economies of Eastern Europe.

Transparency is a key concept in the fight against bribery and corruption. The Working Group consulted on several occasions with representatives of the private sector and civil society who were instrumental in the development of the OECD Convention and whose continuing support is necessary to ensure that it is effectively implemented. An online service was created last year providing access to more than 2500 selected references to books, journals, papers, reports and other documents relating to bribery and corruption, as well as a large number of downloadable resources. 


$\begin{gathered}\text { At the end of 1999, the following countries had deposited their instruments } \\ \text { of ratification or acceptance of the Convention } \\ \text { with the Secretary-General of the OECD }\end{gathered}$
Australia (18 October 1999)
Austria (20 May 1999)
Belgium (27 July 1999)
Julgaria (22 December 1998)
Canada (17 December 1998)
Finland (10 December 1998)
Germany (10 January 1999)
Greece (5 February 1999)
Hungary (4 December 1998)

\section{Taxation policy}

The Committee on Fiscal Affairs (CFA) provides a forum for senior tax policy-makers to discuss current tax issues and to establish the international rules of the game for taxation. Its aim is to eliminate tax measures which distort trade and investment flows, to prevent double taxation and to counteract tax evasion and avoidance. A particular focus of the 1999 programme has been on measures to counter the distorting effects of harmful tax competition, to develop a taxation framework for electronic commerce and to reach out to countries beyond the OECD area.

In response to requests from the OECD Council and the G7 Finance Ministers, the CFA presented to OECD
Ministers in May 1998 a set of recommendations intended to curb harmful tax practices with respect to geographically mobile financial and other service activities. A Forum on Harmful Tax Practices was established to develop a list of tax havens and to identify harmful preferential regimes in Member countries. The Forum is proceeding on three fronts. One front involves counteracting harmful tax practices in OECD Member countries by drawing up a list of harmful preferential tax regimes.

A second front involves tax havens. Jurisdictions on the OECD tax haven list (to be presented to OECD Ministers in June 2000) could be subject to co-ordinated counteracting measures by OECD Member countries. The third front of action involves non-member econo- 
mies that may also be affected by harmful tax practices. The OECD is engaged in a dialogue with such economies to encourage them to associate themselves with the principles and recommendations of the OECD Report. A high-level meeting with non-member economies will be held in June 2000 .

The effective administration and enforcement of tax laws require access to bank information. Globalisation, electronic commerce and liberalisation of capital movements are creating vast opportunities for commercial transactions. These opportunities are available to a broader spectrum of the population and more taxpayers than ever before have easy access to ways to escape taxes legally due, taking advantage of the more restrictive bank secrecy jurisdictions. It is in this new context that the Committee on Fiscal Affairs initiated a review of the current position of Member countries on access to bank information and is working on ways to improve such access.

The OECD is attempting to provide greater certainty in the taxation of electronic commerce. The Ottawa Taxation Framework Conditions endorsed by OECD Ministers in October 1998 provide a principles-based framework to address the issues and harness the opportunities. One of the guiding principles is neutrality of taxation treatment, as compared to taxation for conventional commerce. The OECD is leading the international tax debate and is co-operating with other international bodies (WTO on tariffs, WCO on Customs, etc.) to avoid wasteful duplication of effort. The OECD has established technical advisory groups (TAGs) to discuss the tax issues arising from electronic commerce with representatives from OECD and non-OECD economies and the private sector. It has created an Internet Forum for the public discussion of the opportunities and challenges and published some implementation options. These are based on the framework conditions, for instance on the concept of permanent establishment in the electronic context. The Forum is exploring the best practice opportunities offered by the electronic commerce technologies, such as electronic filing, electronic refunds and payments, improved taxpayer access to information and single points of registration.

The Committee has an important non-member country programme which aims to provide an opportunity for countries outside the OECD to participate in its work and to contribute to experience-sharing on a global basis. One of the objectives of the programme is to associate these countries to the OECD practice (Model Tax Convention, transfer pricing rules, measures to counteract harmful tax competition). This programme is run in part through the OECD Multilateral Tax Centres in Ankara, Budapest, Vienna, Seoul and Beijing and through strengthened co-operation with regional taxation organisations in Asia, Latin America, Africa, Central and Eastern Europe and the Middle East. In 1999, 100 events were held with 40 countries.

\section{Competition law and policy}

In 1999, competition policy took on a higher public profile world-wide with mega-mergers and big cartel cases making headlines. Governments increasingly recognise how sound competition policy supports dynamic, resilient economies. The OECD Competition Law and Policy Committee (CLP) continued to pursue a wide range of activities, including promotion of the convergence of national competition policies, dissemination of best analytical practices, co-operation in competition law enforcement, and pro-competitive regulatory reform. It also intensified its efforts as an advocate for competition policy within the Organisation and a vehicle for the development of sound competition laws and policies in non-member countries. 
A number of best practices round tables were held in 1999 on issues confronting competition authorities. Similarly, a diverse and challenging array of issues will be pursued in 2000 including promoting competition in the natural gas industry; competition and regulation issues in pharmaceuticals; joint ventures and competition policy; bank and financial institution mergers; local cable TV networks; and e-commerce and competition.

In the area of law enforcement and international co-operation, 1999 saw the CLP adopt a report on positive comity. This report addresses requests by one government to another to take enforcement action, provides a sound and consistent framework for discussions of positive comity and assesses its potential benefits, limitations and likely utility in particular types of cases.

Efforts have been intensified to improve the coherence between trade and competition policies. An OECD Emerging Market Economies Forum conference on Trade and Competition (29-30 June 1999) was organised, where academics and representatives of business, trade unions and advocacy groups from 30 nonmember countries, discussed with OECD delegates ways to streamline trade and competition policies in the interests of more open global markets.

Numerous activities were organised to share OECD expertise on competition policy with non-members, including a conference on Competition Policy in the Baltic States, a conference in Shanghai on the Role of Competition Policy in Economic Reform; a conference in Bangkok on Competition Policy in Asia; and a workshop in Moscow on Competition Policy in Banking.

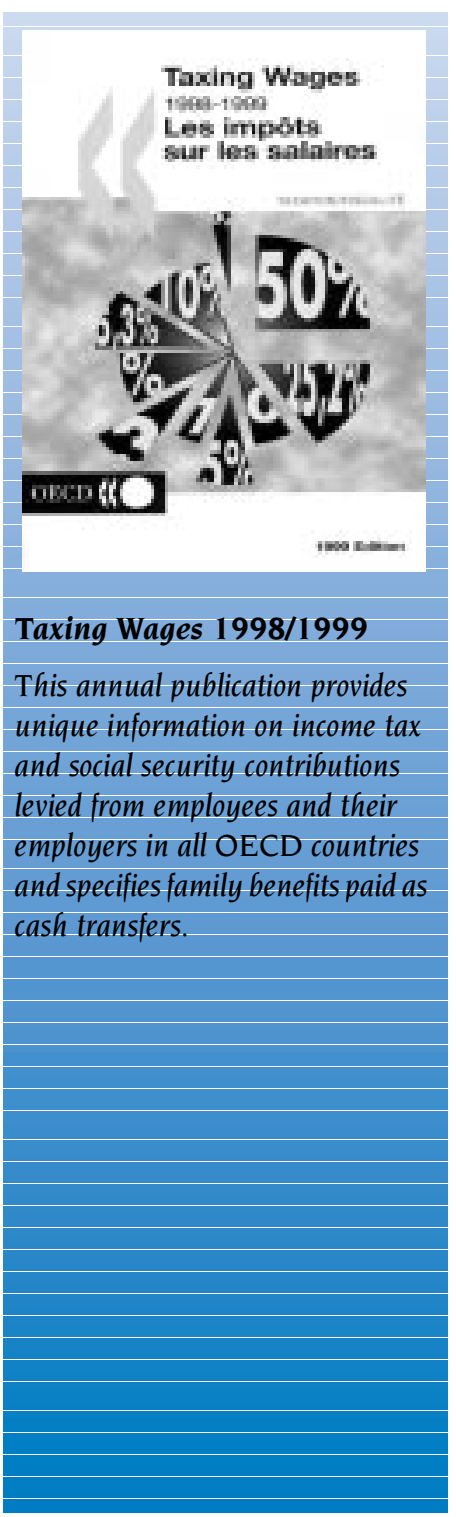




\section{THE FIGHT AGAINST HARMFUL TAX PRACTICES}

www.oecd.org/daf/fa/harm_tax/harmtax.htm

During 1999, OECD Member countries have worked to globalise their efforts, begun in early 1996, to combat tax poaching. The fight against tax poaching is needed to prevent unintended and harmful consequences stemming from the geographic mobility of capital that fuels cross-border trade. Cross-border trade cannot flourish in the long run if tax poaching goes unchecked. Without steps to protect the integrity of tax systems, democracies are at risk. They cannot exist unless funded by fair and accepted tax regimes.

For these reasons, OECD Member countries have joined together to prevent harmful tax practices. The effort is focused on tax practices that permit residents of one country to escape taxes legally due there, by using tax hide-aways or preferential regimes that impede the enforcement of revenue laws. This is not a fight against lower tax rates or against competition, but against predatory practices that endanger the emerging global market and shift tax burdens from dishonest to honest taxpayers.

The work of the past year has been to implement recommendations of the OECD report, Harmful Tax Competition: An Emerging Global Issue, adopted by the OECD Council in April 1998'. The report contains 19 recommendations to counter harmful tax practices in Member countries, in their dependencies, and in non-member economies. The scope of the work is limited to geographically mobile financial and other service activities. This work is being taken forward by the OECD's Forum on Harmful Tax Practices, a body comprised of representatives of the 29 OECD Member countries, under the supervision of the Committee on Fiscal Affairs.

Key criteria for determining whether a tax practice is harmful are exchange of information and transparency. In the case of jurisdictions whose offshore sector predominates in the economy, the criteria include whether the existing regimes encourage investment without substantial domestic activities. In the case of jurisdictions with a substantial domestic economy, the criteria include whether any preferential regimes are ring-fenced from that economy. Regimes with these attributes are deemed harmful because they are not aimed at attracting real activities to the domestic economy.

To implement these criteria and counteract harmful tax practices, the Forum is proceeding on three fronts. One front involves counteracting harmful tax practices in OECD Member countries. The Forum is mandated to draw up a list of harmful preferential tax regimes, and OECD countries that endorsed the Tax Competition report have agreed to roll-back the identified regimes within five years.

A second front involves jurisdictions outside the OECD area that do not have an incentive to co-

1. Switzerland and Luxembourg abstained 
operate in the fight against tax poaching. The OECD report refers to these jurisdictions as "tax havens". For the OECD, a tax haven is a jurisdiction that engages in harmful tax practices under the criteria discussed above and that does not have a significant tax base of income beneficially owned by its own residents. In such circumstances, the jurisdiction would have little or nothing to gain from the demise of tax poaching.

The Forum is mandated to prepare a list of jurisdictions that meet the criteria of being tax havens. Jurisdictions on the OECD tax haven list could be subject to co-ordinated counteracting measures by OECD Member countries. However, jurisdictions that demonstrate a commitment to reduce their harmful tax practices could be given a delay in the application of such measures. The listing of jurisdictions as tax havens, and the subsequent application of co-ordinated counteracting measures, is intended to serve as the incentive for such jurisdictions to join with the international community and co-operate in the fight against tax poaching.

The third front of action involves non-member economies that may also be affected by harmful tax practices. The OECD is engaged in a dialogue with such economies to encourage them to associate themselves with the principles and recommendations of the OECD report. A high-level meeting with nonmember economies will be held in June 2000 .

The OECD Forum is pursuing the possibility of an extended dialogue with tax havens because of a high level of interest by the jurisdictions under review to work towards co-operative change during a reasonable transition period. The OECD sees the potential to provoke meaningful change as a great opportunity, particularly when taken forward through intensified international co-operation. To achieve this objective, effective economic and other assistance will be needed in the transition for jurisdictions that are willing to move towards positive change. 


\section{ENVIRONMENT \\ www.oecd.org/env/}

A new environment programme of work was launched in 1999 to help achieve the Shared Goals for Action which OECD Environment Ministers had agreed upon at their meeting in Paris in April 1998. These stressed the crucial importance of strong environment policies and coherence between economic, social and environmental policies for the successful implementation of sustainable development. Under the guidance of the Environment Policy Committee (EPOC), the Environment Directorate is primarily responsible for delivering the environment programme, which has 12 main activities. The Environment Directorate was also an active contributor in 1999 to a range of horizontal and co-operative activities, notably the project on sustainable development, the revision of the OECD Guidelines for Multinational Enterprises, and work on biotechnology and food safety. Stakeholders from business, labour and environmental non-governmental organisations are increasingly involved in the work. Fuller details of the environment programme and its publications can be found on the completely redesigned Environment Internet site.

\section{Environmental outlook and strategy}

When Environment Ministers next meet at the OECD in 2001 , they are expected to agree on a new Environmental Strategy, which will provide a conceptual and quantitative foundation for the environment pillar of the OECD's work on sustainable development. Work began in 1999 on the first ever OECD Environmental Outlook, which will underpin the Strategy and provide a macroeconomic based assessment of environmental conditions in 2020, focusing on specific sectors and types of environmental concern. The results of the Outlook will begin to be available towards the end of 2000 . They will reveal the extent to which policies may need to change to put OECD countries on a path towards environmental sustainability in the next two decades.

\section{Economic and environmental policy integration}

Promoting the compatibility and mutual reinforcement of economic and environmental policies is central to achieving sustainable development. Work in this area has looked at such issues as market and intervention failures and how to remove them. It has also examined strategies and tools for policy integration in sectors such as agriculture and tax policy. Key results of the work have appeared in a number of new publications, including: The Price of Water - Trends in OECD Countries; Voluntary Approaches to Environmental Policy; Proceedings of the Workshop on Domestic Tradeable Permits for Environmental Protection; and Improving the Environment through Reducing Subsidies, Part III (Case Studies). Work on agriculture in cooperation with the Agriculture Directorate resulted in a new publication on Agri-Environmental Indicators.

\section{Globalisation and environment}

Assessing the environmental implications of economic globalisation, with a particular focus on the effects of trade and investment liberalisation, is the aim of this work. A major international conference on Foreign Direct Investment and the Environment was held in 
The Hague in January 1999, with extensive participation from non-OECD countries. The OECD Guidelines for Multinational Enterprises have the potential to promote the highest standards of behaviour amongst international companies, and in this way to promote sustainable development. Ensuring that the environment chapter of the Guidelines reflects current best practice has been a priority in the course of 1999. On trade and the environment, a Workshop on Methodologies for the Environmental Assessment of Trade Liberalisation Agreements (October 1999), and a publication Trade Measures in Multilateral Environmental Agreements, provided important inputs to the Seattle WTO Ministerial meeting and the continuing debate on trade and the environment which will take place in the course of 2000 and beyond.

\section{Increasing resource efficiency}

Increasing the efficiency with which natural resources both renewable and non-renewable - are used is essential for moving towards sustainable development, and managing them more sustainably is a major challenge for both OECD and non-OECD countries. Technical, social and economic changes can contribute to major improvements in the efficient use of resources, so their underlying causes need to be identified. This new cross-cutting project of the environment programme aims to address these issues. Activities in 1999 led to the completion of a variety of new studies: a Report to the OECD Council on the Implementation of the 1996 Council Recommendation on Improving the Environmental Performance of Government; a Report on the Sydney Workshop on Improving Eco-efficiency; and a Handbook of Incentive Measures for Biodiversity: Design and Implementation. A new study on Economic Issues in Benefit Sharing: Concepts and
Practical Experiences, dealing with the utilisation of genetic resources, was also released.

\section{Sustainable consumption patterns}

Closely related to the work on Increasing Resource Efficiency, this project recognises the fact that OECD countries are the world's largest consumers of natural resources and their patterns of production and consumption have a disproportionate impact on the global environment. It is therefore important to identify how products and services can be consumed with less of a strain on natural resources and lower levels of pollution. The results were released of a September 1998 workshop on Education and Learning for Sustainable Consumption, organised jointly with the OECD's Centre for Educational Research and Innovation, as was a Report on Indicators of Sustainable Consumption. Case studies on sustainable consumption of food, tourism and housing, based on a quantitative and qualitative analysis of each “domain”, will be released in 2000 .

\section{Climate change}

Global climate change is one of the major challenges facing society, and analysis of policies to tackle it is one of the highest priorities of the environment programme. The Directorate undertakes analysis of international issues for the UN Framework Convention on Climate Change through its Annex 1 Experts Group, which supports Member and "transition" countries in their preparations for the negotiations. Work is carried out in close co-operation with other parts of the OECD, as well as the International Energy Agency, and makes a substantial contribution to the OECD project on sustainable development. In March 1999, the OECD Climate Change Forum brought together OECD and nonmember country governments, the private sector and 
non-governmental organisations to discuss the key outcomes of the 4th Conference of the Parties to the UNFCCC and equitable approaches to global participation to reduce greenhouse gas emissions. The 5th Conference of the Parties, held in Bonn in October 1999, was the occasion for the publication of several new reports, including National Climate Policies and the Kyoto Protocol, which provides an overview of efforts in OECD countries and a first attempt to develop an analytical framework for assessing good practice. Numerous other policy and technical studies in support of the implementation of the UNFCCC were released throughout the year on monitoring and compliance, and on emissiontrading and project-based mechanisms. The focus of work in 2000 will be on national policy and on preparations for the 6th Conference of the Parties to be held in The Hague in November 2000.

\section{Environmentally sustainable transport}

The project on Environmentally Sustainable Transport (EST) continued to produce innovative findings on the need for better policies to tackle the environmental and social burden being imposed by growth in the transport sector. Under the guidance of the Working Group on Transport, several experts workshops took place, and a Report of the EST Project: Phase II was published in October 1999. The project will be completed in the course of 2000 following a major conference in Vienna in May 2000 which is expected to lead to the adoption of a set of policy recommendations and guidelines for implementing EST in OECD countries.

\section{Chemicals, pesticides and biotechnology}

The Directorate's work on chemical safety, under the Environmental Health and Safety Programme, much of it financed separately from the rest of the Environment Programme, ensures that the mechanisms needed to maintain a high level of protection for human health and the environment and to avoid non-tariff barriers to trade are in place, and are implemented at least cost. Work on biotechnology and food safety assumed increasing importance in 1999, largely in response to a request from the G8 Summit for a report to its next meeting in July 2000. Seven consensus documents on biotechnology were also published, and the Bio-Track Online Data System further expanded. On the chemicals side, three new Guidelines for the Testing of Chemicals were agreed by Member countries, and further support given to Member countries to implement Pollutant Release and Transfer Registers.

\section{Waste management}

The Directorate continued to support implementation of the OECD Council Acts on the Transfrontier Movement of Hazardous Waste, following a review of the work by EPOC. This review emphasised the need for enhanced harmonisation of the Basel and OECD control systems, if possible by the end of 2000. The value of trade in recoverable wastes among OECD countries, which make up $80 \%$ of the global total, is estimated at US\$25 billion a year. The OECD control system allows for the environmentally safe movement of such wastes and also contributes to improved resource efficiency by facilitating recycling.

\section{Data and indicators}

Environmental data and indicators are essential to effective policy-making, and the Directorate is the authoritative source of such information for OECD countries. The work on environmental indicators also makes a significant contribution to the indicators part of the 
OECD's project on sustainable development, and the Directorate played a key role in the Rome Conference entitled Towards Sustainable Development - Indicators to Measure Progress held in December 1999. Also, in December, a new biennial OECD Environmental Data Compendium was published. Reports on Sustainable Household Consumption Indicators and on Transport/Environment Indicators were also released in 1999.

\section{Monitoring environmental performance}

Data and indicators are also an essential underpinning of the Directorate's peer reviews of Member countries' environmental performance. The publication in 1999 of the reviews of the Czech Republic, Denmark and Turkey brought to 28 the number of reviews completed. The first ever environmental performance review of the Russian Federation was published at the end 1999. The first cycle of reviews will be completed in 2000 , and the second cycle will start, with a stronger emphasis on the use of indicators to measure performance and on the analysis of the integration of environmental, economic and social policies to achieve sustainable development. The social/environmental policy interface was also the theme of an expert workshop held in September 1999.

\section{Dialogue with non-member countries}

Improving dialogue with non-member countries has been increasingly integrated into many of the environment programme's activities, a trend which will continue in 2000. Following the 1998 Environment for Europe Ministerial Conference held in Aarhus, Denmark, the Environment Directorate continues to serve (in partnership with the Regional Environmental Centre, Hungary) as the secretariat of the Task Force for the Implementation of the Environmental Action Programme for Central and Eastern Europe (EAP). In this work, strengthened emphasis is placed on the needs of the New Independent States of the former Soviet Union. A flagship publication Environment in the Transition to a Market Economy appeared in October, synthesising problems and achievements in integrating environmental concerns into economic transition in Central and Eastern Europe. Co-operation with Russia and with China was also strengthened. A seminar on environmental monitoring was held in China in April, and the proceedings of a Workshop on Environmental Taxes in China were published in July.

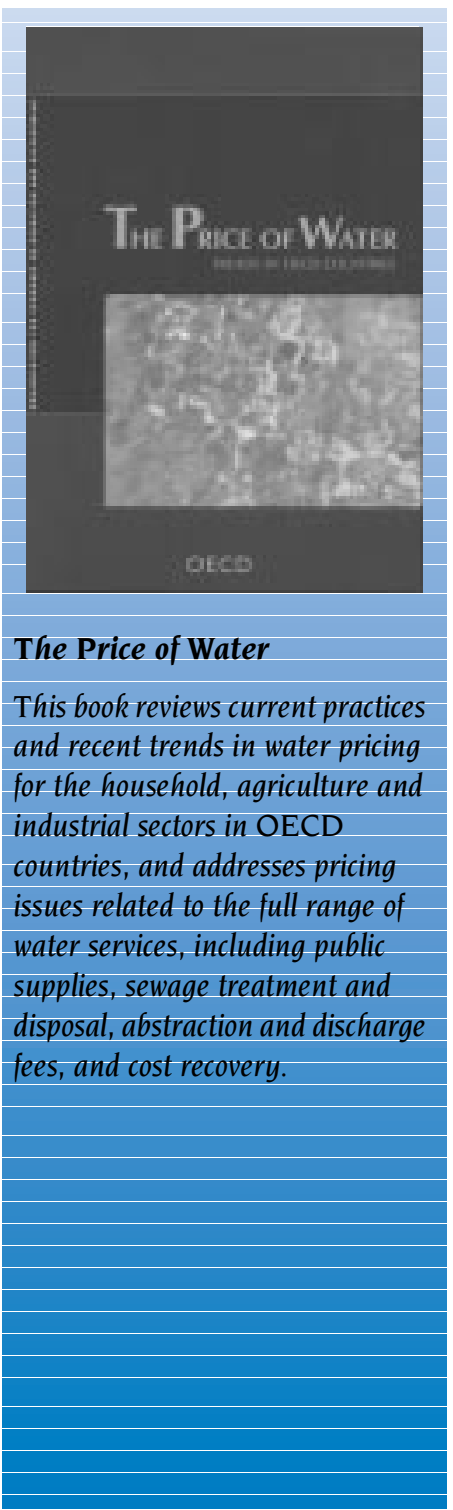




\section{SUSTAINABLE DEVELOPMENT: PROGRESS OF THE OECD THREE-YEAR INITIATIVE}

www.oecd.org/subject/sustdev/

The OECD three-year initiative on sustainable development has now entered its second year. This initiative is based on a strong mandate from the 1998 OECD Ministerial Council meeting and, more generally, follows a call from the High-Level Advisory Group to the Secretary-General that the OECD "should, as a matter of urgency, develop into the key intergovernmental organisation providing the industrialised nations with the analytic and comparative framework of policy necessary for their economies to make the transition to sustainable development".

The Organisation has responded with a major initiative that involves a majority of its Directorates and affiliated organisations (the International Energy Agency, the Nuclear Energy Agency, the European Conference of Ministers of Transport, and the Development Centre). While work on sustainable development issues has a long tradition within the Organisation, much of it was carried out in a decentralised way, often in response to specific sectoral concerns. The objective of the initiative is to bring coherence and visibility to this work, imposing sustainable development as a key principle for policymaking. Progress towards sustainable development will not happen unless attention is focused on it at the highest political level.

As an economic organisation, the OECD has approached sustainable development as a key eco- nomic issue. Economic decisions are driving phenomena like climate change and exploitation of renewable resources beyond their reproductive capacity. Responding to these phenomena requires modifying incentives so that producers and consumers face the full consequences of their actions. More generally, increased economic efficiency and material well-being cannot be sustained if they do not translate into improvements in social and environmental conditions; if their benefits are not shared equitably between and within countries; and if today's progress comes at the expense of the opportunities for future generations. This is the meaning that the Organisation attaches to the concept of sustainable development. Making this concept operational for policies is the major objective of the initiative.

OECD's work over the course of 1999 included the presentation of a first Progress Report and Executive Summary at the time of the 1999 Ministerial Council Meeting, as well as work organised around meetings and conferences:

- A High-Level Meeting on Climate Change in September 1999 gathered officials from economics and environmental ministries, to enhance the understanding of different national positions on the implementation of the Kyoto Protocol. A follow-up meeting is being considered. 
- Meetings of the OECD Round Table on Sustainable Development, an informal gathering of officials (including a number of Ministers) from national governments and international organisations, aim to advance mutual understanding of key issues bearing on sustainable development and to facilitate co-operation, synergies and division of labour between relevant international agencies.

- Expert Meetings on Climate Change Modelling (June 1999) and on Measurement and Indicators (September 1999), brought together academics and representatives from national and international agencies.

- An OECD Conference, Towards Sustainable Development: Indicators to Measure Progress, cosponsored with Italy in Rome in December 1999, reviewed different approaches to the measurement of progress towards sustainable development in Member countries and provided guidance to further OECD efforts in this area.

Outlines for the various components of the documentation envisaged for the 2001 meeting of the OECD Ministerial Council have been developed. A detailed outline and production plan for the various types of documents envisaged are scheduled to be presented in a second progress report in June 2000. The full analytic and policy reports will be discussed by an ad hoc working group in early 2001 . 


\title{
FOOD, AGRICULTURE AND FISHERIES
}

\author{
www.oecd.org/agr/
}

The prime objective of the work undertaken by the OECD Directorate for Food, Agriculture and Fisheries is to assist Member countries to embrace open market approaches and implement appropriate policies to achieve the shared goals identified by OECD Agriculture Ministers in 1998, and to achieve economically efficient sustainable fisheries. In 1999-2000, a comprehensive programme of work on trade and transboundary issues is designed to provide analytical support to the process of agricultural trade liberalisation; the concept of multifunctionality or "non-trade concerns", which are important issues in agricultural trade negotiations, is explored. Issues related to sustainable agriculture and the environment and the interests of emerging and transition economies are being increasingly integrated into the analyses, particularly as they relate to further trade liberalisation. Two major core activities, and accompanying publications, continue to provide the overall background for these analyses: the annual Agricultural Policies in OECD Countries: Monitoring and Evaluation and the Agricultural Outlook.

\section{Measuring agricultural support and monitoring policy developments}

The 1999 edition of Agricultural Policies in OECD Countries: Monitoring and Evaluation analysed developments in 1998 against the shared goals, policy principles and operational characteristics for policy measures agreed by the Ministers for Agriculture in 1998. After a decade of gradual decline in support and protection, new measures, not always consistent with longer term reform goals, were introduced by some governments in 1998, largely in response to low world prices. The level of support to agriculture, as measured by the Producer Support Estimate (PSE) increased to $37 \%$ of the value of farm receipts in 1998, against 32\% in 1997. A more comprehensive classification of support measures was used for the first time in this edition and provided additional insight into the nature of increasingly complex policies. Efforts to strengthen the process of monitoring and evaluating policy changes by the addition of quantitative impact analysis will be further enhanced in the pilot project on the Policy Evaluation Matrix, preliminary results of which will be published in 2000 .

\section{The Agricultural Outlook}

The sixth issue of the OECD Agricultural Outlook, covering the period 2000 to 2005, will be published in April 2000. The report concludes that a recovery in global commodity prices and a continued increase in agricultural trade will be likely. This assumes more favourable macroeconomic conditions and a continuation of agricultural policy reform in OECD Member countries. But the report also points to ad hoc measures taken to assist producers in coming through a period of depressed commodity markets, and to the danger that such measures, if producers begin to anticipate them, will affect resource allocation and market adjustments. The report also notes that the medium-term market outcomes are contingent on the way in which governments deal with emerging civil society concerns linked with the side effects of modern agricultural production methods. The need for government measures to deal 
with these emerging issues which are consistent with continued policy reform and trade liberalisation is stressed in this respect. The report also has a focus on a number of important policy issues, such as the impact of modern biotechnology on supply and markets, the Agenda-2000 Berlin Agreement and the integration of China in the multilateral trading system. In a number of cases, the OECD's AGLINK model is used to evaluate the impacts of these developments against the background of the baseline projections.

\section{Agricultural trade liberalisation}

Work in 1999, continuing in 2000, focused on in-depth assessment of the impact of the Uruguay Round Agreement on Agriculture (URAA) on levels of protection and trade in agriculture. This involves a thorough examination of notifications, trade flows and other data to determine to what extent the agreement has reduced trade distortions. Preliminary results confirm that, despite very important systemic improvements, the agreement has not to date had dramatic impacts on trade. Work is also in progress to assess the impact of further liberalisation on trade and world markets. A range of scenarios concerning different approaches to further discipline on market access (tariffs and TRQs), and export subsidies will be explored. The AGLINK model is being modified to make it appropriate for this analysis and the Secretariat is playing a leading role in a joint activity with a number of Member countries and international organisations to establish the database on market access. The results of this work, to be made available throughout 2000, are expected to be important in assisting policy-makers in elaborating their negotiating strategies. The work on export subsidies will be supplemented with an analysis focusing in particular on the subsidy equivalent of officially supported export credits. A start has also been made in
2000 with work looking into the effects of trade liberalisation on food security. A number of other issues at the interface of domestic and trade policy are being explored. They include competition policy, state trading, agri-environment and trade linkages, and decoupling. Trade considerations arising from food safety and quality issues that will be examined include biotechnology, labels of geographical origin and animal welfare.

\section{Multifunctionality and adjustment}

The idea that agriculture provides outputs in addition to its primary function of supplying food and fibre has become an issue for the next round of agricultural trade negotiations. The OECD work seeks to provide a clarifying and rigorous framework within which these issues can be explored and appropriate policy conclusions drawn. Two key issues currently addressed are the extent to which food and other outputs of agriculture effectively result from "joint production", and the valuation of positive and negative externalities. The first results of this activity should be available in late 2000 .

Farm-level and agro-food sector structural databases were completed in 1999. Work has begun to investigate the response of farm employment to policy changes. A survey of changes in land use in OECD countries was completed. A study examining the distributional effects of agricultural policies was also published. Work in 2000 will focus on the incidence and causes of low farm incomes and on approaches to deal with income risk management, with the latter to be the subject of a workshop in May 2000.

\section{Agriculture and environment}

The achievement of sustainable forms of agricultural production is a widely recognised goal. Drawing on the analysis of sustainable agriculture, and the linkages 
between agriculture, trade and the environment, as well as the evaluation of agri-environmental policy measures and the development of agri-environmental indicators, work in this area will contribute to establishing the criteria and characteristics of "good" agrienvironmental policy measures in the context of agricultural and trade policy reform. Progress was made on identifying the conditions under which farmers should take into account the environmental harm they cause, and be remunerated for the environmental benefits they provide. This work will be synthesised in a report to be finalised in late 2000. It will also provide the basis for the chapter on agriculture in the analytical report of the OECD horizontal project on sustainable development to be submitted to the Ministerial Council Meeting in 2001. A report on Environmental Indicators for Agriculture: Methods and Results, to be published in mid2000 is a comprehensive stocktaking of the progress to date in indicator development across OECD countries. It constitutes a valuable step toward clarifying the current state and trends in environmental conditions in agriculture. An OECD workshop, hosted by the Netherlands in July 2000, will examine the adoption of technologies for sustainable farming systems.

\section{Policy dialogue with non-members}

The policy dialogue with major agricultural producing and trading non-members in the biannual Forum on Agricultural Policies in Non-Member Economies focused in early 1999 on the impact of the Asian financial crisis on agriculture in emerging and transition countries, concluding that food and agricultural markets were generally adversely affected. The seventh edition of Agricultural Policies in Emerging and Transition Economies warns against a return to protectionist policies, which could prolong the adverse effects of the crisis for agricultural producers in many countries. It also takes a critical look at two other issues crucial to ongoing reform in the agro-food sector: labour adjustment in rural areas and the development of agricultural land markets. The annual special section, Watch on Support, showed that there was substantial growth in go-vernment support to producers in 1998 in Estonia, Latvia, Lithuania and Slovakia and a significant decline in Russia, the latter due largely to macroeconomic factors. The Forum launched at the end of 1999 an indepth analysis of agricultural trade policy reform from the point of view of emerging and transition economies. This two-year project will assess URAA implementation and raise key issues for those countries in the evolving WTO negotiations.

Due to the potential of the agro-food processing sector to contribute significantly to China's economic and social development, a workshop dedicated to trends and policy challenges in this sector was jointly organised in Beijing with the Chinese Ministry of Agriculture. The Workshop urged the Chinese authorities to avoid direct involvement as market player or agro-processor, stressing instead the government's role in creating a policy environment that allows market forces to work and in addressing externalities.

An expert meeting in Moscow, co-sponsored by Japan, addressed the topic of agricultural finance and credit infrastructure, a major issue for Russia and many other reforming economies. It concluded that without a market-based economy, the role of market-based financial instruments for the agro-food sector remains limited. The restoration of trust and confidence is needed. To achieve this, the government's role in putting into place an integrated and sustainable legislative, financial and institutional framework is essential.

Major reviews of agricultural policies in Bulgaria, Slovenia and Romania were launched. Their finalisa- 
tion in 2000 will complete the series of policy reviews for the ten EU pre-accession transition countries, contributing a significant body of policy analysis to the integration process of these countries into the European and world economies.

\section{Agricultural codes and schemes for international trade}

The updating of international trade rules for agricultural seed, forest reproductive material, tractors and fruit and vegetables continued. These rules were extended to additional non-member countries. A new activity launched under the seed schemes addresses consumer information and mutual recognition aspects of seed certification, thus contributing to the OECD-wide activity on biotechnology and other aspects of food security.

\section{Biological resource management for sustainable agricultural systems}

In March 1999 a major conference brought together high-level scientists, directors of research institutes, and representatives of industry, farmers organisations, consumers and the media, to discuss sustainable agricultural systems and explore the connection between science, policy-making and society.

Ninety-two fellowships were awarded under the 1999 fellowship programme for periods up to six months, thereby promoting scientific exchange among the 26 OECD Member countries participating in the programme. Recognising the contribution made by the fellowship programme to the work in the field of sustainable development and biotechnology, it has been extended for another five years. The programme will be organised around four new research themes of increasing policy relevance, address- ing issues of public concern such as food safety and the effects of agricultural practices on the environment.

\section{Fisheries}

Analytical and empirical work on the economic and policy implications of the transition to sustainable fisheries advanced considerably in 1999. In early 2000 results were published in Transition to Responsible Fisheries: An Evaluation of Costs and Gains. This study covers four areas of work: fisheries labour and adjustment to responsible fisheries; post-harvesting practices and responsible fisheries; government financial transfers and resource sustainability; and modelling the transition to responsible fisheries. In addition to being of key importance to the work of the Committee for Fisheries, the study provides input into the OECD horizontal activity on sustainable development.

Published early in 2000, the Review of Fisheries in OECD Countries (1999 edition) details trends and policy developments and includes fisheries statistics covering the years 1995-1997.

The communiqué of the 1999 OECD Council Meeting at Ministerial Level refers to the importance of timely international agreement and action on the effective and sustainable management of fisheries resources and the relationship between resource management and trade. Furthermore, the Council endorsed OECD's ongoing examination of the impacts of government financial transfers and other relevant factors on fisheries resources sustainability, including over-fishing. Based on this, and as a follow-up to the work on transition to responsible fisheries, core activities for 2000-2002 will cover fisheries sustainability indicators, fisheries management costs and fisheries market liberalisation. 


\section{SCIENCE, TECHNOLOGY AND INDUSTRY \\ www.oecd.org/dsti/sti/}

The Directorate for Science, Technology and Industry and its committees seek to help Member countries adapt to the challenge of the "knowledge-based" economy. The Directorate informs governments on emerging scientific, technological and industrial trends and offers a forum for policy dialogue. The Directorate also identifies areas where OECD-wide standards, or "rules of the game", may help to avoid international friction.

\section{Industry and business}

The Industry Committee organises regular Business and Industry Policy Forums to bring major stakeholders together to discuss topical issues. Recent subjects include the industrial aspects of the Asian financial crisis and the implications of the services economy. In 2000, discussions will focus on drivers of the "new economy" and on industry and sustainable development.

National approaches to corporate governance, intangible investment, venture capital, regulatory reform and other parameters are compared to improve government policies for creating a favourable business environment. Trends in industrial globalisation - including cross-border mergers and acquisitions, and international strategic alliances - are also assessed for their policy implications. In all of its work, the Industry Committee brings a sectoral perspective to general issues, i.e. how they affect sectors ranging from steel to electronics to business services.
The Working Party on Small and Medium-sized Enterprises (SMEs) is concerned with general conditions for entrepreneurship, e.g. financing, taxation, management training. A manual to help SMEs deal with the potential Y2K or "Millennium" bug was published in 1999 and widely circulated. Current activities include helping small firms, notably in accessing electronic commerce. Conferences in 2000 will examine enhancement of the international competitiveness and globalisation of small firms and the concerns of women entrepreneurs.

The Science, Technology and Industry Scoreboard 1999 includes new indicators that better reflect the evolution of the "knowledge-based economy" in OECD economies. Several regular data sets were published, providing key economic variables by detailed industry grouping, including a new database which breaks out the activities of domestic and foreign-owned firms. Data quality issues continued to be addressed, particularly in the light of changing methodologies in Member countries. Significant progress was made on the development of handbooks on productivity measurement and measuring price developments in computer markets, and in developing guidelines to measure globalisation and its relationship with economic performance.

\section{Science and technology}

The Committee for Scientific and Technological Policy (CSTP) met at Ministerial level to address new policy challenges arising from the expansion of scientific and technological knowledge, its increasing influence on the patterns and dynamics of economic growth, and its 
contribution to sustainable development and social well-being. Ministers reaffirmed the essential role played by science systems in knowledge production but also in addressing social, economic, educational and environmental needs. In setting new directions for future policy, they gave high priority to measures aimed at raising the efficiency of support and incentive schemes for public and private RED capabilities, improving the innovative performance of their economies and encouraging researchers' entrepreneurship. They recognised the need for increased dialogue with the scientific and business communities and society at large to maximise the potential benefits of science and technology.

In 1999, work was initiated to enhance the CSTP's ability to monitor and assess changes in SET and innovation policies and their impact on economic performance. This work will continue in 2000 and give rise to the publication of the STI Outlook 2000. Work on better understanding the determinants of innovative performance, in order to identify best practice policies, continued and included two new activities: benchmarking science/ industry relationships and the development of research-based spin-offs. Work commenced on the potential role of the social sciences in policy assessment and formulation.

The Megascience Forum completed its activities in 1999. The Forum approved final reports and recommendations from its working groups on radio astronomy, nuclear physics and biological informatics. At the CSTP meeting at Ministerial level, Ministers endorsed the establishment of the Global Biodiversity Informatics Facility (GBIF) and the Task Force on Radio Astronomy Spectrum Issues. They also endorsed the creation of the OECD Global Science Forum, to succeed the Megascience Forum. Activities to be developed by the Global Science Forum in 2000 and subsequent years will focus on high-priority science policy issues requiring international consultation and/or co-operation.

CSTP work on biotechnology for human health, industrial sustainability and on SET infrastructure benefited from the increased interest of Member countries in biotechnology, genetically modified organisms, food safety and its broader impacts. The importance of new methods of detection derived from biotechnology to address the growing burden of water-borne infectious disease was recognised.

The Workshop on Scientific and Technological Infrastructure - Support for Biological Resource Centres, held in Tokyo in February 1999, launched a major new activity which will affect the future development of the entire sector. In 2000, workshops and activities will continue this work, focusing on new genetic tests, the contribution of biotechnology to preventing disabling conditions in the elderly, and surveillance and biosafety issues requiring international co-operation.

Benefiting from new statistical series in the areas of intangibles, patents, innovation and tax relief to RED, The Knowledge-based Economy: A Set of Facts and Figures was presented to CSTP Ministers. In addition to updating and diffusing existing SET indicators, work will continue on testing and developing new SET indicators on patents and innovation. Work was started on updating various methodological manuals to improve the relevance of SET indicators in the light of changes in OECD economies, and to develop new areas (biotechnology statistics).

\section{Electronic commerce}

Following the Ottawa Ministerial Conference of October 1998, the OECD has worked to implement a seven-point Action Plan covering consumer protection, privacy protection, authentication, access to and development of infrastructure, analysis of economic 
impacts, development of statistics and taxation. Other OECD projects on electronic commerce include SMEs, government use of e-commerce, developing country issues and international trade. In October 1999, the OECD Paris Forum on Electronic Commerce brought together governments, business, international organisations and NGOs to take stock of the first year's achievements in implementing the Action Plan. The Forum was preceded by parallel events organised by business and by Public Voice, a consortium of organisations representing elements of civil society.

These events, especially the latter, marked a new phase in the dialogue among stakeholders in the new digital economy, particularly regarding consensusbuilding on policy between governments, business and civil society. The Forum was marked by a deepening consensus in favour of an integrated approach to regulation and self-regulation for electronic commerce. In 2000, work will continue on the various elements of the Action Plan, with an emphasis on promoting effective self-regulation. An Emerging Market Economy Forum on electronic commerce to be held in the second half of the year, will be attended by a widely representative group of non-member economies.

\section{Information, computer and communications policy}

In the light of the Action Plan agreed at the Ottawa Ministerial conference, electronic commerce provided the main, though not exclusive, focus for work in 1999-2000, under four main themes:

- Development of the information infrastructure by improving user access to services, based on regulatory reform and promotion of market liberalisation, taking into account the convergence of communication and broadcasting services, the infrastructure requirements for global electronic commerce and the evolution of the Internet.

- Building confidence in networks by developing guidance on applying the 1980 OECD Privacy Guidelines in today's online environment, and by work on the development of globally-recognised authentication and certification mechanisms.

- Analysis, including that contained in the OECD Communications Outlook (1999) and OECD Information Technology Outlook (early 2000).

- Cutting edge work on the definition and measurement of the information society. This methodological work has been followed by the collection of OECD statistics on the information economy and the production of new indicators to monitor international developments in the information society and related policies.

\section{Consumer policy}

A major achievement was the adoption of the OECD Guidelines for Consumer Protection in the Context of Electronic Commerce in December 1999. Work in 2000 will focus on promoting their effective implementation. Other activities included product safety, sustainable consumption, online advertising and marketing targeting children.

\section{Sectoral issues}

\section{Maritime Transport}

Based on work carried out in 1999 on regulatory reform in maritime transport, the Maritime Transport Committee (MTC), in conjunction with the Committee on Competition Law and Policy, will hold a workshop in May 2000 with stakeholders from industry to canvass a broad range of views in this area. A project proposal was developed in 1999 for work in 2000 on cargo liabil- 
ity regimes, considered necessary as a result of an increasingly complex international scenario involving numerous agreements. Consultations will take place with other international bodies working on cargo liability, such as the International Maritime Organization (IMO), United Nations Commission on International Trade Law (UNCITRAL) and the Comité Maritime International (CMI).

The Committee concluded an understanding with the Dynamic Non-Member Economies (DNMEs) on principles to be applied to international shipping. Close collaboration between the MTC and DNME will be sought in preparing for the resumption of negotiations on maritime transport services within the General Agreement on Trade in Services at the World Trade Organization. Relations with China were strengthened through a Workshop on Opportunities to Increase the Efficiency of Maritime Transport. This dialogue could take on special importance if China joins the WTO.

\section{Shipbuilding}

The Council Working Party on Shipbuilding strengthened its activities to encourage a more level playing field in the shipbuilding sector given the current critical market situation and the absence of the entering into force of the OECD Shipbuilding Agreement. The continued aim is to improve transparency in the sector by intensifying work on supply and demand, and by providing governments and the industry with information and analysis on market conditions.

\section{Steel}

Despite anticipated improvements in the world steel market in 2000, trade tensions remain high. Members and observers of the Steel Committee recalled the Chairman's statement of November 1998 on the Strengthening of an Open and Global Steel Trading System. They stressed the unique role of this body as a forum for discussing and influencing international steel trade policies and promoting transparency in steel policies of participating countries.

A workshop on the situation of the steel industry in the NIS (New Independent States of the Former Soviet Union) highlighted the importance of non-member activities in the Steel Committee's work programme. The Committee emphasised the need for involving other key non-member countries in its work, where such participation would have mutual benefits. India will participate as an observer in the Steel Committee as from 2000.

\section{Road Transport}

Four new policy-focused projects were begun in the areas of socio-economic analysis and intermodal issues: evaluation of measures to reduce $\mathrm{CO}_{2}$ emissions, effects of transport infrastructure investment on regional development, influencing road traffic demand, and benchmarking of modal and intermodal performance. A draft Strategic Directions paper was prepared to facilitate identification of possible research projects that could address emerging policy issues in Member countries. Two major policy reports were published, Dynamic Interaction between Vehicle and Infrastructure Experiment (DIVINE); Safety Strategies for Rural Roads. Three workshops were held in conjunction with the PIARC World Road Congress, Kuala Lumpur: Transport of Dangerous Goods through Road Tunnels, Rural Road Safety, and Road Performance Indicators.

An evaluation of the Road Transport Research Programme, undertaken during 1999 by an independent consultant, concluded that the programme has an established reputation for producing high-quality reports with a strong international perspective. The report recommended that the programme become 
more involved in projects at both the strategic and technical levels.

Selected outreach activities were conducted, including a Conference in Poland on the Strategic Environmental Impact Assessment of Transport (in co-operation with the European Conference of Ministers of Transport) and a Seminar on Information and Documentation in Transport for Latin America.

\section{Tourism}

The Tourism Committee (TC) approved a new strategy for further work on tourism issues and a strengthening of its regular Tourism Policy reviews. Italy was examined in 1999. The Committee organised a Round Table on Regional Policy and Tourism. The TC completed its international guidelines on Tourism Satellite Accounts and Employment Measurement. New projects focus on investment and economic development, associating non-member economies, and on the liberalisation of tourism-related activities.

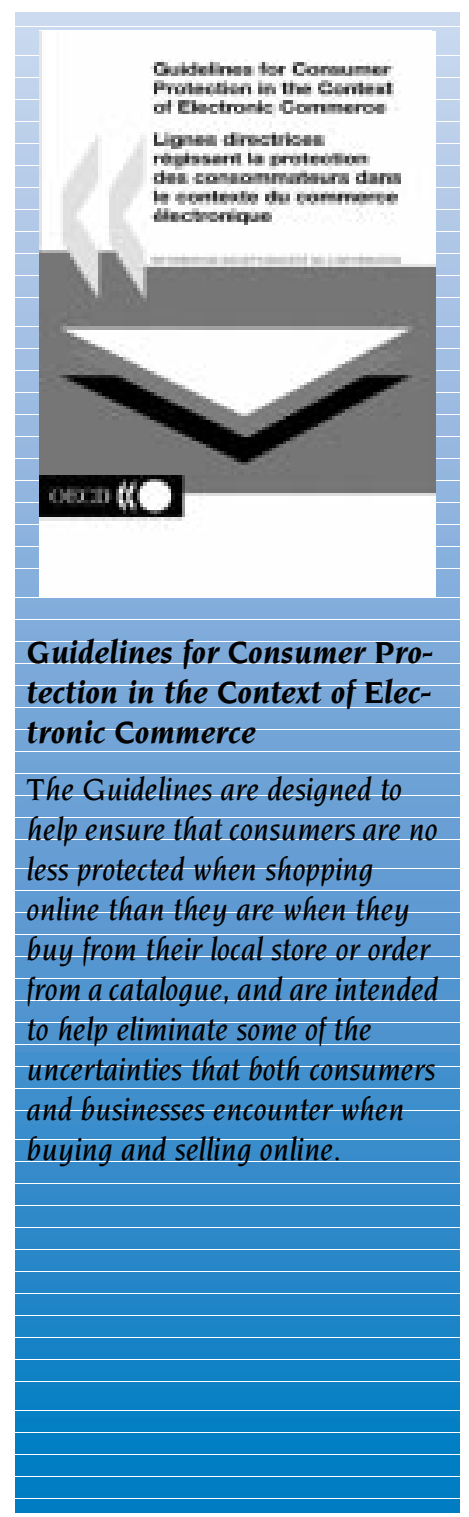




\section{BIOTECHNOLOGY AND FOOD SAFETY}

www.oecd.org/subject/biotech/

Public concern over biotechnology and other aspects of food safety grew during 1999, as increased production of genetically modified (GM) crops coincided with several unrelated outbreaks of food-borne illness, particularly in Europe. There are concerns about possible adverse effects on human health, possible negative effects on the environment, as well as ethical concerns, some of which are connected with the patenting of life forms. The benefits of GM foods should also be borne in mind, including their potential to increase food production for a growing global population.

Regulatory oversight in the food sector traditionally focused on such matters as residues, contaminants, processing aids, packaging materials and labelling - everything, in short, except the food itself. Only as modern or novel technologies, including GM foods, became available did public interest and regulatory attention turn to the main food components or the whole foods themselves. As this occurred, national and international differences emerged over what constitutes justifiable or acceptable risk, the definition of risk and appropriate risk assessment methodologies. Disagreements also arose over the adequacy of available scientific evidence, over the definition and application of the so-called "precautionary principle", and over approaches to labelling GM foods. Finally, different approaches to intellectual prop- erty rights with respect to the patenting of life forms became evident.

To address public concerns, while avoiding trade barriers and trade disputes, scientific findings on the implications of the technologies for human health and the environment need to be presented clearly. Science must underpin policy, taking into account the fact that scientific evidence may sometimes be incomplete or equivocal. Regulation needs to be consistent with scientifically defined risks. Similarities and differences in regulation across countries need to be analysed in relation to rigorously defined standards. Governments and the scientific community must be transparent in presenting findings on risks and in taking measures to address them.

OECD Member governments and the G8 have turned to the Organisation to assist them to develop and refine their approaches to biotechnology (including GM crops) and food safety. The OECD has been building expertise on biotechnology for more than a decade. The Organisation has excellent capabilities for dealing with all aspects of the issue, using a science- and rules-based approach. To complement the ongoing work of various OECD committees, a new Ad Hoc Group on Food Safety was created in November 1999 and charged with preparing a compendium of current and planned international and regional food safety systems and activities. 


\section{PUBLIC MANAGEMENT}

www.oecd.org/puma/

The work of the Public Management Service (PUMA) is based on the premise that good governance is a necessary condition for sustainable economic development and social cohesion. In May 1999 OECD Ministers declared that good governance is "an essential element in strengthening pluralistic democracy and promoting sustainable development". PUMA seeks to:

- Identify and address strategic governance challenges.

- Assist Members and non-members to raise the performance of their public institutions so that they are better equipped to manage those challenges.

- Focus on developing capacities for more coherent and globalised policies, how to meet policy commitments in a changing world, institutionalising transparency, honesty and accountability in government, intervening effectively in society and markets to achieve public policies and promote competition as well as social cohesion.

The annual meeting of the network of Senior Officials from Centres of Government was hosted by the Italian government, in Naples in October 1999. The main theme of the meeting was how governments can strengthen their connections with citizens. An informal discussion identified a range of pressing issues, notably, how to balance budgetary and political issues in public policy decision-making over the medium or longer term and how to sustain political will over time.

A questionnaire, three working parties and several case studies were used to acquire a better understanding of the legal framework in the Member countries for developing relations with citizens. A forthcoming report will identify the key issues for governments in strengthening their relations with citizens.

In 1998, OECD Ministers adopted a Recommendation on Improving Ethical Conduct in the Public Service. In support of that ministerial mandate, PUMA conducted an in-depth survey on managing ethics in the public service in all OECD countries to provide a comprehensive database for analysis and to identify promising practices in various national environments.

In September, PUMA held a symposium on Government of the Future: Getting from Here to There. Eighty highlevel reformers examined the new challenges that governments are facing in advancing government reform. The symposium focused on how to redirect the functions of government in response to social changes, the proliferation of influencing forces outside of government, and the changing role of government itself. A publication based on the symposium findings will soon be available.

In 1999, PUMA updated information on the most important developments in public management and governance issues in each Member country. PUMA is seeking to enlarge the range of information sources for Members by providing a single point of access to a comprehensive and up to the minute set of governance and public management information.

\section{Budgeting and management}

The Working Party of Senior Budget Officials met on 3 4 June 1999. Country reviews of budgeting systems 
were advanced in 1999 with a review of Canada. These reviews provide an overview of the budgetary system of the country in question and offer the opportunity of peer review by the Working Party of the Senior Budget Officials. The Netherlands is scheduled for review in 2000. As part of the Organisation's overall emphasis on transparency, the Senior Budget Officials Working Party initiated a study of OECD Member practices in the area of fiscal transparency and, following an extensive survey by the Secretariat, will consider the adoption of best practice guidelines in 2000. The Working Party also discussed managing budgets in times of fiscal surpluses which has become a challenge for many Member governments.

Managing Accountability in Intergovernmental Partnerships is a topical issue for OECD Members. In 1999, PUMA produced a publication based on six Case Studies undertaken. In March 1999, PUMA arranged an expert meeting to assess the policy relevance of productivity measures in the government sector and to identify an appropriate way forward for PUMA to assess the productivity impact of public sector reforms. The measurement of outputs is an area of mutual interest between national statisticians and public managers.

\section{Human resource management}

The core competencies and professional values of the civil service are critical to enable OECD Member countries to respond to major social changes. A symposium on Government of the Future, held in September 1999, devoted a plenary session to Civil Service Leadership. In January 2000, an expert group convened to identify future human resource management issues. In 2000, PUMA will focus on leadership, strengthening public sector professionalism and ethics, managing knowledge, and meeting critical skill shortages.

\section{Work on regulatory management and reform}

OECD's work on regulatory reform emphasises regulatory quality - combining efficient regulation where needed to protect health, safety, and the environment and to enhance the functioning of markets, and deregulation where appropriate to allow markets to work better. The work programme on regulatory management has focused on helping governments develop new capacities and identify best practices for improving regulatory decisions. The intent is to establish a longer term basis for efficient and responsive regulation by changing incentives, capacities, and cultures in public sector institutions, based on market, juridical, and public management principles.

During 1999, PUMA started to assess concepts of regulatory quality, discuss quality assurance tools, and identify emerging issues. This work will determine the extent to which Member countries have implemented regulatory disciplines such as those in the 1995 OECD Recommendation on Improving the Quality of Government Regulation. This work aims to produce the first comparative benchmarks of regulatory and administrative environments for small and medium scale enterprises. In 1999, surveys in 11 countries (Australia, Austria, Belgium, Finland, Iceland, Mexico, New Zealand, Norway, Portugal, Spain, and Sweden) were completed, and country reports prepared for each of them.

Regulatory reform affects the implementation and performance of public policies, that is the capacity of the government to take effective action in the public interest. One important aspect of effectiveness is the level of compliance. In 1999, PUMA completed for publication a report on pressures against good compliance in 
OECD countries, and started work on a survey of best practices in key policy areas.

\section{Contribution to OECD horizontal activities}

PUMA continued to lead the horizontal OECD work on regulatory reform, under the direction of a Deputy Secretary-General. The OECD-wide country reviews on regulatory reform have made substantial progress. The first set of reviews (Japan, Mexico, the Netherlands, and the United States) was published in 1999, and a second set (Korea, Spain, Denmark and Hungary) will be published in 2000. Reviews of a third group of countries, including Italy, Ireland, and Greece, got under way in 2000. Additional countries have expressed interest in being reviewed in 2001. These reviews have largely validated the policy recommendations in the 1997 OECD Report to Ministers and increased understanding of the complex relationships between the regulatory framework and the functioning of a democratic market economy. They have also identified systemic regulatory inefficiencies and failures, and parallel gaps in the OECD work programme on regulation.

\section{Outreach}

In 1999, PUMA contributed to a manual published by the Asian Development Bank (ADB) on Public Sector Expenditure Management. PUMA also participated in a technical workshop on Public Administration and Civil Service that was held at the Bank Headquarters in Manila on November 29-December 2, 1999. This meeting provided the opportunity for dialogue with officials from non-member economies and for dissemination of OECD promising practices. This workshop will lead to a forthcoming publication.
The SIGMA Programme, a joint initiative of OECD and the European Union's Phare Programme, principally financed by Phare, advised 13 Central and Eastern European countries on reforming core management systems of government. SIGMA prepared a detailed assessment of the readiness of ten EU candidate countries to meet the conditions of membership in six areas of public administration. The Commission used this work in its progress reports on the candidates (autumn 1999). As an illustration of its more than 100 activities during the year, SIGMA conducted peer reviews by experienced OECD country auditors of supreme audit institutions in the Czech Republic, Estonia and Latvia. These reviews helped to establish plans and priorities for strengthening the control of government spending and adopting European standards for state audit.

PUMA is developing with APEC a joint work programme as part of the APEC theme, "strengthening markets." This will to enhance the exchange of information on good regulatory practices and promote the individual and collective implementation of the regulatory reform principles adopted by APEC. The government of Russia has expressed interest in conducting a business survey on burdens on SMEs. Preparatory work began in 1999. 


\title{
REGULATORY REFORM
}

\author{
www. oecd.org/subject/regreform/
}

The OECD work on regulatory reform carries forward the broader structural reform of Member countries. Its multidisciplinary programme, involving public management, economics, competition, trade and sectoral expertise aims to identify good regulatory practices and produce concrete policy advice for Member countries. The emphasis is on regulatory quality - combining efficient regulation where needed to protect health, safety and the environment and to enhance the functioning of markets, and deregulation where appropriate to allow markets to work better.

As the OECD Report on Regulatory Reform and the ongoing programme of country reviews show, regulatory reform that enhances the capacity of the economy to adapt, innovate and otherwise to respond to consumer needs can stimulate economic growth and help economies make the most of the opportunities of globalisation and technological change. At the same time, good regulation can help governments achieve important public policy goals in areas such as safety, health and environmental protection. Yet reform must be welldesigned and carried out - with an understanding of all the major policy objectives at stake - to achieve its full potential, to manage the transition to greater competition and to minimise adverse consequences.

Current developments are reinforcing the relevance of regulatory reform. For its members, the European Monetary Union is augmenting the importance of structural reforms that increase economic flexibility. The 1997 economic crises in Asia underscored the importance of structural issues, including regulatory regimes that are transparent, open and in accord with international standards, while the return to sustainable growth in those countries places continuing emphasis on structural and regulatory reforms. The focus on employment creation in many countries has drawn attention to the need for a high-quality regulatory regime that supports investment, innovation and entrepreneurship.

To assess progress and support the adoption of good regulatory practices in Member countries, a programme of country reviews was launched in 1998, based on multidisciplinary analysis, benchmarking and extensive peer review by five OECD committees and the International Energy Agency. The first set of reviews (Japan, Mexico, the Netherlands, and the United States) was published in 1999. A second set (Korea, Spain, Denmark and Hungary) is being published in mid-2000. An additional four reviews, including Greece and Ireland, are planned in 2000.

The outreach activities of the Organisation draw attention to the role of regulatory reform in promoting strong markets and sustainable growth. The findings and best regulatory practices reported in the OECD Report to Ministers on Regulatory Reform and the country reviews are being widely disseminated. In this connection, the OECD is co-operating with APEC in efforts to promote regulatory reform among members of both organisations. 


\section{EDUCATION, EMPLOYMENT, LABOUR AND SOCIAL AFFAIRS}

www.oecd.org/els/

\section{Labour market policies, employment and unemployment}

The editorial of the 1999 Employment Outlook highlighted the educational and labour market policy reforms necessary to give young people a better chance to establish good careers. The text drew heavily on the lessons from a high-level conference in Washington in February 1999, the proceedings of which were published under the title Preparing Youth for the 21st century. Other topics addressed in the Outlook included: the quality of part-time jobs; a major reassessment of the relationship between employment protection legislation and labour market performance; a comparative analysis of continuing job training for adults; and a detailed examination, using heretofore untapped data, of new work organisation practices and their impacts on the labour market.

Evaluation of what works and what does not work and why with respect to active labour market policies and the role of the Public Employment Service (PES) continued to be a key theme of the work programme. 1999 saw the publication of a review of the PES in the United States, which emphasised not only active and passive labour market policies, but also reviewed the successes and failures of current welfare reform in the US. A review of labour markets and social safety nets in Korea was started and will be published in 2000. Furthermore, following on a decade of intensive analysis of the PES, a high-level conference on the future of labour market policies and the PES will take place in Prague in July 2000. It is anticipated that this conference will give a new direction to OECD's work on labour market policies in the coming years.

\section{Social policy and health}

Work commenced on developing a set of OECD Social Indicators, to aid in the assessment of social policy impacts. The first edition of the resulting compilation will be published during 2000. Work on disability policies and on policies to reconcile work and family life was begun. The second edition of the database on Benefits Systems and Work Incentives was issued, and further analytic work on employment-oriented social policies was launched. A workshop on Making Work Pay was held jointly with the Economics Department; the proceedings are to be published in a special issue of OECD Economic Studies. A third review of social assistance policies was published, covering Canada and Switzerland.

A questionnaire on how national policies and reforms relate to the recommendations in the 1998 OECD report, Maintaining Prosperity in an Ageing Society, has been sent to all Member countries. The responses to the questionnaire will form the basis of a report to the OECD Ministerial Council in June 2000, and to the G8 Summit meeting to be held in Okinawa in July 2000. An intensive review of retirement income policies in nine Member countries also commenced. 
The 1999 edition of the OECD Health Data database and software contained improved documentation, and an initial annual meeting of correspondents supplying the data was held to improve data collection and reliability. A project to investigate the cost-effectiveness of alternative treatments of particular ageing-related diseases was launched, and a conference on Understanding Trends in Severe Disability amongst the Elderly was held. Work continued on analysing the determinants of the effectiveness of health-care systems in improving health outcomes. This surveyed health-care systems in general and the pharmaceutical market in particular. Pilot implementations of the OECD System of Health Accounts (SHA) started in several countries and were discussed during a joint OECD/Eurostat workshop. The SHA manual is to be published early in 2000 .

\section{International migration}

A seminar on Preventing and Combating the Employment of Foreigners in an Irregular Situation was held in The Hague in April 1999. This seminar was jointly organised by the OECD and the Dutch authorities, with the support of the United States (the proceedings will be published in spring 2000). Policy recommendations arising from the seminar will be followed up during the annual meeting of the Working Party on Migration in June 2000.

The annual report on Trends in International Migration analyses recent trends in migration movements and policies. In 1999, the special chapter was devoted to the economic and political issues associated with clandestine migration. It illustrated the different situations of irregularity, the methods employed to measure its extent, its impact on the labour market and the sanctions imposed on employers.

\section{Non-member economies}

A chapter on labour market and social policy developments was contributed to the report on The Baltic States - A Regional Economic Assessment. The report will be published in 2000. A follow-up review on labour market and social policies in the Slovak Republic was held in Bratislava in May 1999. A mission in several districts of Russia took place in May and June in order to prepare a review of social and labour market policy in Russia. A review of labour market and social policies in Romania was prepared and will be discussed with the Romanian authorities in early 2000.

In the framework of the Joint Vienna Institute, two courses were delivered in March and September 1999 on Labour Market and Social Policies. In December, a seminar was organised on Pension Policy and Pension Reform which provided an overview of the current state of pension reform in OECD countries and transition economies.

Education activities included the publication of the Review of Tertiary Education and Research in of the Russian Federation and a special meeting of the Education Committee in Bucharest for the review of education policy of Romania. The site visits for the education reviews of Estonia, Latvia and Lithuania also took place.

\section{Education and training}

Developing strategies for lifelong learning and monitoring progress in their implementation continued to be the main focus of work. In evaluating the implications of policies for the allocation and use of resources, quality and standards, the Education Committee examined such issues as early childhood education and care, school-to-work transition, financing lifelong learning and the learning needs of adults. The 1999 issue of Education Policy Analysis showed that it is how 
education investments are made, not just the level of such investments, that counts. A report to be published in 2000 advances a new way of looking the reporting of human "intangible assets" in firms. The final report from the International Adult Literacy Survey (to be published in 2000) extends the analysis to 21 countries and confirms earlier findings that a large proportion of OECD's adult population exhibits low literacy skills. A report from a thematic review covering 14 countries provided guidance on how to improve the transition between schooling, training and work and helped prepare the ministerial-level conference on the subject held in London in February 2000. Follow-up reviews of the Czech Republic and Korea highlighted different strategies for implementing educational reforms.

\section{Centre for Educational Research and Innovation (CERI)}

CERI is at the forefront of research and innovation in a broadly-defined education, training and learning environment. Key activities in 1999 included: the development of several new indicators including those on changes over time in the financing of education and the links between human and social capital in relation to sustained economic development; identification of significant innovations for the schools of tomorrow, in particular the role of information and communications technology (ICT) in education and learning; analysis of recent developments in the management of knowledge in the health, education and ICT sectors; analysis of successful attempts to combat social exclusion through strategies of inclusion into mainstream education for children and youths and into active life for adults; new developments in the internationalisation of higher education; the evolution of learning cities and regions; and the launching of a new project on learning science and brain research and its potential implications for education policy and practice.

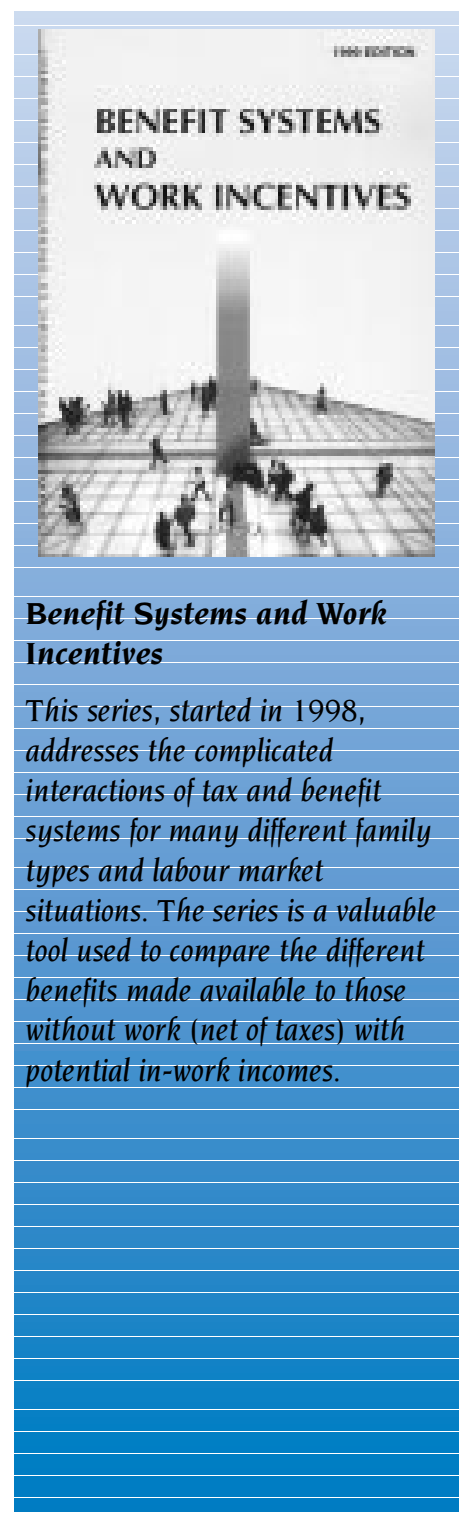




\title{
TERRITORIAL DEVELOPMENT SERVICE
}

\author{
http://www.oecd.org/tds/
}

The Territorial Development Service (TDS) assists Member countries in developing and implementing policies to increase prosperity and well-being at the regional and local levels. Territorial policy complements macroeconomic and sectoral policy. It enhances the potential of territories, reduces regional disparities and optimises the allocation of decision-making between central government and regional and local authorities. Through local initiatives, it contributes to priority national objectives such as sustainable development, good governance, decentralisation and business and job creation. Lastly, it boosts the efforts of local partnerships, the third sector and civil society as a whole.

\section{Territorial policy reviews}

The Territorial Development Policy Committee, established in January 1999, reviews policies carried out country-wide or at the level of individual regions, whether urban, rural or intermediate. In its recommendations, the Committee takes into account the requirements of sustainable development and looks for efficient implementation of policy proposals at the appropriate level of government. Its findings are published in the OECD Territorial Reviews series. Country reviews are scheduled for Hungary, Italy and Korea. The Committee will also oversee reviews of rural and intermediate regions in the Czech Republic, France and Greece, and review an urban region in Italy.

The territorial reviews focus on:

The geographical allocation of activity and infrastructure and the interdependence of cities and rural areas (spatial development policy).
- Measures to enhance regions' potential, to reduce disparities and to increase market efficiency and factor productivity (economic development policy).

- Issues of disparity and social exclusion, and measures which strengthen both human and social capital and improve equal opportunities, living conditions and quality of life for all (social development policy).

Complementary work covering experience in a number of countries takes consideration of territorial policies a stage further. This helps to define some of their characteristics more sharply (scope, obstacles, benchmarks), to identify the most promising policies, and to validate their effectiveness. This work, along with prospective analysis of various kinds, is published in the OECD Territorial Outlook. The new role played by spatial planning strategies was the topic for a conference in 1999, and another conference on the links between globalisation and decentralisation is to be held in 2000 .

\section{Urban affairs}

Urban sprawl was the subject of a major conference in Mexico City which brought together representatives from Latin America as well as from OECD Member countries. An environmental and economic strategy for the Lagan River, and partnership and investment strategies to rebuild Belfast were the subject of an evaluation and a seminar (held in co-operation with OECD's TUAC). The Belfast evaluation and seminar papers will be published in 2000, as well as a final report on urban sprawl and the regeneration of urban brownfields. The 
Belfast study will be complemented by additional studies of cities demonstrating a capacity for an urban renaissance.

The OECD welcomed an invitation from Japan to host a series of three seminars (in Kobe, Matsue and Tokyo) on the policies appropriate for a mature urban society, where cities are no longer growing through rapid ruralto-urban migration. These seminars assessed urban conditions in Japan from an international perspective. The findings will be relevant to the revision of urban policy for the future.

In 1999, the Territorial Development Policy Committee adopted a set of principles of metropolitan governance. In 2000, relevant events include a conference on housing and ageing in cities, and initiation of a project on the analysis of environmental management systems by the private sector and local authorities in urban areas.

\section{Rural affairs}

Top priority has been given to the study of how rural amenities may contribute to rural development; in particular, what are the best ways for rural people to realise value from amenities, and how they can balance the preservation of amenities with the development of their local or regional economies. In May 1999, TDS published Cultivating Rural Amenities: An Economic Development Perspective, a report that synthesises findings from the different phases of research undertaken by the OECD over the past few years, including conceptual and theoretical work, case studies and international workshops. As a follow-up to this report, additional research will be carried out in the area of monetary valuation of non-market goods and creation or simulation of markets for amenities. Future work will consist of the analysis of environmental management systems in rural areas as well as a study of the factors of growth in these areas.

\section{Territorial statistics and indicators}

In 1999, the Service intensified its efforts to describe territorial disparities and trends towards regional convergence and divergence. The territorial database was made more multifaceted in order to incorporate additional analytical perspectives and respond to new demands from within TDS. Particularly significant progress has been made in the area of mapping. For each Member country a cartographic representation at two different sub-national levels is now available.

The importance of territorial statistics and indicators for improving understanding of national and regional dynamics prompted the Territorial Development Policy Committee to create a Working Party on Territorial Indicators. The Working Party objectives are to define the relevant territorial frameworks for territorial analysis and to propose structures and systematic methods for compiling relevant indicators in order to study how territories develop.

\section{Local Economic and Employment Development (LEED)}

The LEED Programme primarily focused on the following areas:

\section{Innovations in decentralisation, local management of employment and training and job creation.}

Following the publication in May 1999 of Decentralising Employment Policy: New Trends and Challenges, a study project on local partnerships was launched involving fieldwork in eight countries. The first stage of the project will conclude at the end of 2000 with a final 
report proposing policy recommendations aimed at making partnerships more effective. A second key issue is how to transfer best local development practices. The publication on Best Practices in Local Development studies this question in depth. Other important matters on the local development policy agenda were addressed at the Local Economic Development: Social Capital and Productive Networks conference in Mexico City.

\section{Fostering entrepreneurship at the local level}

Fostering entrepreneurship at the local level is a cornerstone of local economic renewal and employment growth. The publication Business Incubation: International Case Studies was released in September 1999, and a conference on the same theme was held in Albi, France the following month. This work represents one of the first attempts at an international comparative analysis of the incubation industry, and one which is highly topical because of the growing popularity of incubation schemes. The LEED Programme also addressed the issues of youth entrepreneurship and self-employment at an international conference entitled Enterprise Creation and Local Development, in Rome in November 1999, which will be the subject of a publication in 2000. The Programme also studies the impact of globalisation on the local dimension of entrepreneurship and seeks to define the proper scope and content of public policy towards clusters and networks of small firms. In order to strengthen international awareness of such local clusters and facilitate work in the field of job creation, the International Club of Local Clusters was created in Paris in October 1999. The Programme is furthermore responsible for the workshop entitled Partnerships, Clusters and SME Globalisation at the OECD Ministerial conference on Enhancing the Competitiveness of SMEs in the Global Economy: Strategies and Policies, to take place in Bologna in June 2000.

\section{Combating unemployment and social exclusion through integrated local strategies.}

Two publications highlighting new local policies on social cohesion were released during the year: The Local Dimension of Welfare to Work and Social Enterprises. Further work on the evaluation of social enterprises and the non-profit sector in Europe and the United States will be published at the end of 2000. The LEED Programme will also inaugurate two Fora: the Forum of Cities and Regions and the Forum on Social Innovations.

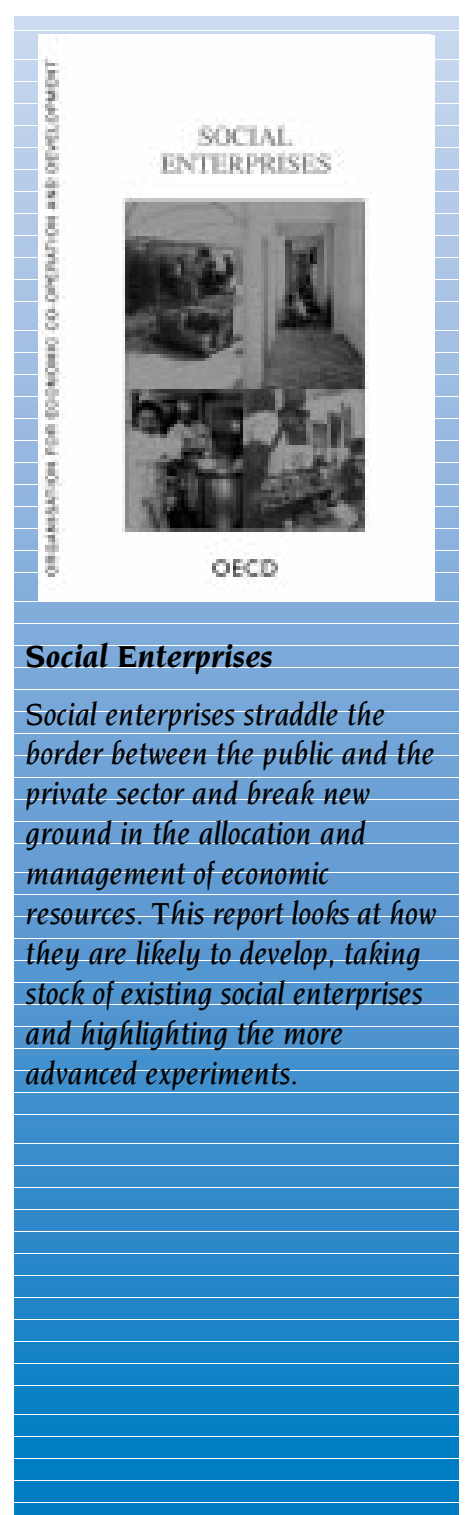




\section{CO-OPERATION WITH NON-MEMBERS}

www.oecd.org/sge/ccnm/

The OECD currently maintains policy co-operation with approximately 70 non-member economies. Through the Centre for Co-operation with Non-Members (CCNM), OECD Member country officials and experts engage their counterparts in non-member economies in policy dialogue and conduct peer assessments without conditionality while sharing each other's rich and varied policy experiences. This absence of conditionality is rare in the international arena and gives nonmembers the ability to participate with the OECD in frank and open discussions on a broad range of issues of mutual interest.

The establishment of the South Eastern Europe programme, and the continuing adaptation of its three thematic programmes, demonstrate the CCNM's ability to respond to developments outside the OECD area and to the needs of Members, non-member economies and the international community as a whole. While the OECD continues to have an important role in assisting transition economies in Central and Eastern Europe and the New Independent States to meet their historic challenge of transforming into market economies, the CCNM is also engaging a larger number of non-member economies in other regions in discussions on global, horizontal issues.

\section{A new high-level instrument for co-operation}

OECD co-operation with non-members received an added impetus in 1999 from the first Special Dialogue with non-members at Ministerial Level held in con- junction with the annual meeting of the OECD Council at Ministerial Level. Ministers from seven nonmembers - Argentina, Brazil, China, India, Indonesia, the Russian Federation, and the Slovak Republic - met with their counterparts from the OECD countries to discuss key issues under the theme of Policy Coherence in the Global Economy: Opportunities and Challenges of Interdependence. Discussions confirmed the increasing policy interdependence between OECD and partner countries and the need for the OECD to stay engaged in policy dialogue with a wide range of non-member economies.

\section{Observerships}

Observerships are another instrument for non-member economies to contribute to and benefit from the work of the OECD. The participation of non-member economies expands the scope of committee work, opening new channels for dialogue and the exchange of expertise. More than 20 non-members participate in over 30 committees and other subsidiary bodies of the Organisation, including those dealing with trade, investment, economic development reviews, environment, financial and fiscal affairs, maritime transport, steel, science and technology, industry, employment, labour and social affairs, and agriculture and fisheries. In 1999, Estonia, Latvia and Lithuania were invited to participate in the discussions of the Committee on International Investment and Multinational Enterprises (CIME) on issues relating to international investment; and Singapore was invited to become an observer in the Committee on Financial Markets. 


\section{Thematic Programmes}

\section{Emerging Market Economies Forum (EMEF)}

In 1999, the EMEF emphasised activities that promote long-term dialogue rather than one-off events, through the creation of networks of contacts or series of specialised forums on policy areas such as agriculture, corporate governance, or environmental aspects of globalisation. It became an important instrument to engage non-member economies in discussions on global issues such as international taxation and competition policy. Meetings were held under the auspices of the Investment Policy Forum, which provided impetus to the integration of environment and FDI policies by focusing on practical methods to ensure that policies are mutually reinforcing. Work also advanced coherence of competition policies between Members and non-member economies. Dialogue on taxation policy assisted in the adaptation of legal frameworks to accommodate emerging global issues, including harmful tax competition and development of bilateral treaties to avoid double taxation. The 2000 programme continues to highlight global issues and emphasises the integration of non-member economies into multilateral "rules of the game" in the key areas of capital markets, trade, taxation, environment, competition policy, policies to foster entrepreneurship and in some specific sectors of the economy such as steel and maritime transport.

\section{Transition Economies Programme (TEP)}

In 1999, critical work was undertaken by the Istanbul Centre for Private Sector Development in promoting financial sector reform and enterprise development; by the Multilateral Tax Centres to assist in tax system reform and the establishment of legal and administrative frameworks; and by the Joint Vienna Institute (JVI), a co-operative venture among six major international organisations for training in such basic governmental tools as economic policy management. Substantial support for capacity-building in economic statistics focuses on the technical capacity of transition economies to compile internationally comparable statistics. Key economic indicators were produced for a number of transition economies along with the completion of purchasing power parities and the development of business tendency surveys. SIGMA, a joint initiative of the OECD and the European Union, principally financed by the EU's Phare Programme, advised Central and Eastern European countries on public administration reform. For 2000, TEP activities will focus on policy areas of particular concern to transition economies including support for the integration of transition economies into the international trading system and trade implications of regional co-operation involving transition economies; financial disclosure, accounting and audit reform; competition policy design and implementation; implementing tax reforms in Transcaucasian and Central Asian NIS; combating corruption; investment policy reviews; and implementing private sector development policies. Policy-makers from transition economies are also invited to activities in the EMEF programme recognising that, in select policy areas, they can benefit from the participation of counterparts from around the world.

\section{Country and regional programmes}

\section{Russia}

Throughout 1999, the OECD played a critical role in supporting market-oriented reforms. While OECD activities have been supporting reforms at the working level, they have also made an impact at higher levels, most notably through the completion of a third survey 
of the Russian economy, an environmental performance review, and the establishment of the Corporate Governance Round Table in co-operation with the World Bank and Russian authorities. 2000 will be a critical year for the programme as it works in partnership with the new government to nurture a reform vision and ensure that the achievements of the past decade of co-operation are entrenched in the new government's policies. Specifically, the Russia programme aims in 2000 to engender incentives for good public and corporate governance; facilitate enterprise development; accentuate sub-national, regional development; and monitor Russia's progress towards meeting OECD membership requirements. The 2000 programme will continue the traditionally successful activities in, for example, tax reform, agriculture, competition law and policy, anti-bribery, promoting foreign direct investment and the development of a sound banking sector and public and corporate governance.

\section{China}

With the China programme, the OECD aims to facilitate China's integration into the world economy by bringing together OECD Member country experts and Chinese officials in various areas of policy dialogue to exchange expertise and experiences. The programme has marked a number of successes to date including the training of over 1200 Chinese tax officials by OECD Member country experts. The visit of the Secretary-General to China in 1999 provided Ministerial endorsement and stimulus to the programme, emphasising the unique relationship that the OECD has with China. 1999 can be characterised as the year when a number of critical projects were launched in China, many at the express request of the Chinese authorities; they will be carried forward in 2000. These projects include: a study on the macroeconomic and structural features of reforms of the enterprise sector; work on developing environmental indicators; policy advice on improving the regulatory framework for attracting FDI by multinational corporations; modernisation of the budget and financial management.

\section{Brazil}

The Brazil programme builds upon and synthesises the substantive expertise developed throughout the OECD through Brazilian participation in EMEF activities, as an observer in a number of OECD Committees, and as a member of the Steel Committee and the Development Centre. An OECD mission to Brazil in 1999 received a very positive response from the Brazilian authorities and further strengthened the basis for a long-term and fruitful dialogue. The "flagship" activity of the programme is a Country Economic Survey. The survey will provide a comprehensive review of the Brazilian economy and its key challenges. It will guide the development of activities with Brazil.

\section{Baltic Regional Programme}

The Baltic Regional Programme is an innovative approach to co-operation between the OECD and nonmember economies. Financed to a significant extent by voluntary contributions from the Nordic countries, Poland and, new for 2000, Ireland, the Baltic programme has received very active political support from the Baltic governments. The design, development and implementation of the various activities, as well as the evaluation exercises, are undertaken in close concert with the Baltic countries and the financial supporters. The 1999 "flagship" activity was a regional economic assessment, published in early 2000, which provides insight into the economic issues confronting the Baltic region. Other high-profile activities in 1999 included the establishment of the Baltic Forum for Entrepre- 
neurship and Enterprise Development (FEED), and a competition policy review. Carrying forward into the 2000 programme are policy reviews in the fields of foreign direct investment, education, insurance and pension reform. A review of social and labour market policy will be launched in the second half of 2000 . These reviews, which will be the basis for the elaboration of medium-term objectives for the programme, will serve as yardsticks to gauge its implementation.

\section{Emerging Asian economies}

In response to the financial crisis that began in 1997, the OECD has initiated a programme to deal with the remaining questions of longer term economic, financial and social reconstruction. The 1999 programme of work has deepened the policy dialogue on the institutional and structural reforms required for a successful and sustained economic recovery in the most affected nonmember economies notably Malaysia, Indonesia, the Philippines and Thailand. Activities centre on improving corporate governance, competition and tax policy, reforming financial markets, strengthening capacities to respond to social consequences of recessions, and containing the negative effects of the East Asian crisis on trade and trade policy in the longer term. For 2000, the programme is expected to promote the wider use of acknowledged institutional and policy practices in these areas, as well as to enhance the Organisation's in-house expertise on complex policy issues such as governance and social safety nets in Asia.

\section{South Eastern Europe (SEE)}

The OECD has been actively involved in the Stability Pact for South Eastern Europe since its inception. The Pact provides the framework for international efforts to lay the foundations for long-term peace and sustainable economic development in the region. The
OECD Programme on South Eastern Europe is anchored in the Stability Pact. It includes support for the Compact for Reform, Investment, Integrity and Growth, good governance, the Stability Pact's Anti-Corruption Compact, economic monitoring, statistics. It also covers ongoing country-specific activities, in particular with Bulgaria, Romania and Slovenia, although as far as possible activities are on a regional level to promote co-operation among the countries in the region.

\section{The Slovak Republic}

At the 1999 Meeting of the Council at Ministerial level, Ministers stated that they looked forward to the conclusion of the process of accession of the Slovak Republic. The process gained momentum throughout 1999 as the Slovak Republic and the OECD reviewed the obligations that must be met by the Slovak Republic in order for it to be invited to join the Organisation. Also in 1999, progress was made on the implementation of the recommendations of both the economic review and the review of labour and social policies.

\section{Co-operation with other international organisations}

Throughout 1999, the CCNM continued to develop cooperative arrangements with international and regional organisations around the world. These cooperative arrangements have been instrumental in intensifying the impact of CCNM programmes; encouraging synergies among organisations to promote common goals; and sharing expertise and knowledge. Activities have been undertaken with, for example, the World Bank, the International Monetary Fund (IMF), the European Bank for Reconstruction and Development (EBRD), the Asia Pacific Economic 
Co-operation Forum (APEC), the Southern Common Market (MERCOSUR) and the Asian Development Bank (ADB). The CCNM intends to expand its network of "partnership" arrangements by reaching out to more organisations and deepening existing relationships.

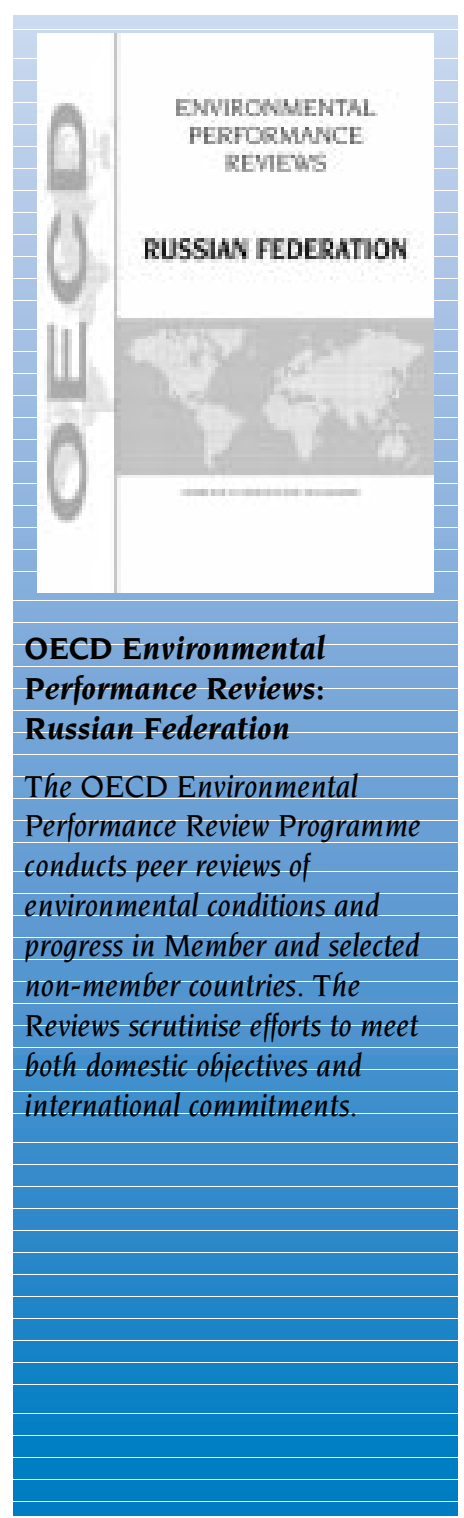




\section{DEVELOPMENT CO-OPERATION \\ www.oecd.org/dac/}

The year 1999 saw major progress towards the adoption in the international development co-operation system of the objectives and principles called for in the 1996 Report on Shaping the 21 st Century: The Contribution of Development Co-operation. This central policy statement of the Development Assistance Committee (DAC) has influenced the adoption across the international development community of a core set of development goals and the introduction of new partnership modalities. This progress was captured in a paper, On Common Ground, submitted by the DAC Chairman to the September 1999 meetings of the World Bank and IMF in Washington. A further major step forward was taken at those meetings with the decision of the World Bank and IMF to base their support for low-income countries on poverty reduction strategies and partnership principles. All of this progress reflects a new level of strategic co-operation between the OECD and other multilateral organisations - in particular the World Bank, the IMF and United Nations family - to reinforce the complementarities and potential synergies between OECD development co-operation work and their partnership efforts. The DAC will add further thrust in this direction in 2000 when an extensive range of work on development co-operation policy and practical guidelines will be brought to fruition.

\section{Advancing development goals and measuring performance}

\section{Poverty reduction}

The international commitment to reduce extreme poverty by one half by 2015 has compelled donors to start assessing, re-thinking and transforming their modes of operation in accordance with the new, more demanding requirements for performance and results. In this context, the DAC Informal Network on Poverty Reduction carried out a horizontal survey of donors' poverty reduction policies and programmes in 1999. The recently published result of this effort, the DAC Scoping Study of Donor Poverty Reduction Policies and Practices, proved to be an exceptionally rich source of information and analysis about the strengths and shortcomings of donor efforts to reduce poverty. (The study is available on the DAC Internet site.) Findings subsequently were used as a point of departure for formulating the structure and contents of the forthcoming DAC Guidelines in Support of Poverty Reduction. These guidelines, to be completed in 2001, will not only be the product of a donor consensus on good practices, but also the outcome of a broad dialogue with partner countries. Regional consultations will be organised in Africa, Asia and Latin America in the first half of 2000 to ensure that the perspectives and concerns of partner governments and civil societies are fully reflected in the guidelines.

\section{Core indicators for development}

A core set of development indicators has now been widely accepted by the international community as a way of measuring progress towards the attainment of the international development goals. The feasibility of broadening the range of environment indicators and including indicators of good governance within the set has been examined. Final agreement on the core set is expected in March 2000. New data and indicators will be added to the DAC Internet site as they become available. 
Since an indicator set is only as good as the data that support it, the World Bank, IMF, OECD and UN Stats Division got together with senior partner country representatives in November 1999 to launch an initiative to boost statistical capacity in developing countries. PARtnerships In Statistics for Development in the 21 st century (PARIS21) aims to support countries' abilities to monitor development progress and policy effectiveness through the use of national statistical systems as the basis for the supporting information used in policy frameworks. Three task forces are to be set up under the initiative to assess the data requirements of policy frameworks, build strategic statistical master plans and promote best practice and effective technical co-operation in building statistical capacity. Reports on progress will appear on the Internet at www.PARIS21.org.

\section{Gender equality}

The poverty reduction, social development and environment sustainability goals set out in the 21 st century Strategy are unlikely to be reached unless sustained attention is given to the promotion of gender equality. The DAC Working Party on Gender Equality, therefore, focused its efforts on documenting how donors could most effectively link the gender perspective with the achievement of these development goals, based on proven donor practice. Three reference documents, available on the DAC Internet site, have been released. They address gender equality in health, education and environment. Work continued to promote knowledge of practical methods for incorporating the gender dimension in economic analysis and policymaking in such instruments as national budgets, public expenditure reviews and sector programmes. Publication in 2000 of a consolidated report on gender and economics will lead to further work on enhancing gen- der analysis in sector wide approaches focusing specifically on agriculture, education and health. The results of a self-assessment survey of progress made by donors in implementing the DAC High-Level Statement on Gender Equality (1995) will be discussed by the DAC in 2000 and forwarded as input to the UN Beijing +5 Review. In 1999, the annual joint workshop with the UN Inter-Agency Committee on Women and Gender Equality discussed human security and women's empowerment. In 2000, the workshop will focus on governance.

\section{Environmental sustainability}

A key goal of the 21 st century strategy is to have a national strategy for sustainable development (NSSD) in the process of implementation in every country by 2005 so as to reverse current trends in the loss of environmental resources by 2015. A review by the DAC Working Party on Development Cooperation and Environment of experience in supporting developing countries in this area has highlighted the importance of integrating social and environmental objectives within existing economic development planning and policy processes. By clarifying the basic principles underlying successful NSSD processes, this review has laid a sound basis for further dialogue with developing country partners. As a next step, the Working Party will organise a series of informal consultations in Asia, Africa and South America with a view to formulating policy guidance for donors in this area. The Working Party is also identifying practical ways for donors to help developing countries meet their obligations under the three Rio Conventions (desertification, biodiversity and climate change). A special focus is on finding ways to advance the objectives of several conventions at once, while fostering development objectives as a whole. The group is also actively contributing to the 
DAC work on poverty reduction by identifying the complex linkages between poverty reduction, gender equality and environmental sustainability, and their implications for sustainable development policies.

\section{Participatory development and good governance}

Lessons learned from the in-country co-ordination and consultation process in good governance conducted by a number of DAC Members in six pilot countries were discussed at the April 1999 meeting of the DAC Informal Network on Participatory Development and Good Governance. In order to constitute a body of experience and best practice, these lessons will be assessed in 2000 together with governance processes conducted by other organisations and institutions. These will include, for example, the European Union, the Organization of American States, the Economic Commission for Africa, the Southern African Development Community, the Institute for Democracy and Electoral Assistance, and the Inter-American Development Bank.

\section{Strengthening partnerships and improving aid effectiveness}

\section{Putting partnership principles into practice}

Observing the convergence of partnership approaches now being advocated by all major developing agencies as well as many developing countries, the Chairman of the DAC brought the fundamental principles of these and other partnership approaches together in a paper titled On Common Ground: Converging Views on Development and Development Co-operation at the Turn of the Century. Such a common set of principles would not only highlight the international community's determination to work in partnership, it could also provide a strong basis for a genuinely concerted effort to make partnership work on the ground.

In 1999 a Development Partnership Forum - jointly organised by the DAC, the World Bank and the UNDP met with development partners. They reviewed aid coordination to build on the experience and develop genuine partnerships. The Forum concluded that the modalities of development partnership and co-operation must be country specific and that instruments should be adapted to country-level processes led by developing country governments. The main elements for closer cooperation will include capacity-building for managing development resources by the developing countries themselves, harmonisation of donors' operational policies and procedures, joint monitoring and evaluation based on jointly agreed indicators of development progress with developing countries, improved sharing of information on promising and innovative approaches to partnership. These issues will be pursued throughout 2000 in the context of the informal group of multilateral secretariats chaired by the DAC Chairman. In addition, the DAC will pursue its mainstream development partnership work programme through active co-operation in peer reviews, harmonisation efforts, and providing guidance on how to implement widely shared partnership principles.

Other major activities in 1999 included a Workshop on the Institutional and Capacity Development Aspects of the Partnership Approach, organised by the DAC's Informal Network on Institutional and Capacity Development. This workshop addressed in depth the lack of institutions and capacity in developing countries as an obstacle to the broad implementation of sector-wide approaches (SWAps). Meanwhile, progress was made with implementing the recommendations for reforming the international aid system in Mali, following the review carried out by the DAC between April 1997 and 
March 1998. The final report on the review became available in 1999.

\section{Peer reviews}

Peer reviews of the relevance and effectiveness of development co-operation programmes of DAC Member countries are a unique and central part of the OECD's work in development co-operation. They focus on long-term strategies, policy guidelines, aid organisation and management, performance, policy coherence, examples of best practices and comparative and statistical reporting. Each Member's aid programme is assessed on a four-year cycle. During 1999, peer reviews were carried out for Denmark, Japan, Ireland, Norway, Austria and Australia. In 2000, reviews are planned for France, New Zealand, Italy, Sweden and Switzerland. The summary and conclusions of all peer reviews are available on the DAC Internet site.

\section{Aid evaluation}

The DAC Working Party on Aid Evaluation started a new series of publications entitled Evaluation and Aid Effectiveness Series. The first issue Guidance for Evaluating Humanitarian Assistance in Complex Emergencies was released in November 1999 and the second Evaluating Country Programmes, Vienna Workshop 1999 was published in December 1999. These are free distribution publications and the costs are entirely covered by voluntary contributions. Other major activities in 1999 included a Workshop on Evaluating Poverty Reduction Programmes in Development Co-operation and a Workshop on Evaluating Gender Equality and Women's Empowerment.

Work began during the year on results-based management, evaluation partnerships and a new glossary of terminology. As the processes set in motion by the partnership strategy in development co-operation began to take a stronger hold in operational terms among various institutions, Member interest in promoting joint evaluations and more collaboration in all phases of the evaluation cycle became more manifest.

\section{Bringing together policies affecting developing countries}

\section{Trade and development}

Trade provides a major means by which developing countries can achieve higher rates of economic growth and make serious progress in reducing poverty. A recent OECD study calculated that full and global liberalisation of tariffs would improve Sub-Saharan African countries' GDP by 3.7\%. This implies annual gains of US\$1 1 billion - an amount almost equivalent to DAC Members' ODA to this region in 1997. However, it has also been estimated that an entire year's development budget would be required in many of the least developed countries in order to implement WTO agreements such as Customs Valuation and TRIPS.

In a collaborative programme of work between the DAC, the Development Centre and the Trade Committee, support will be given to the fuller participation of developing countries in the multilateral trading system, in order for them to benefit fully from the opportunities created by the rules-based multilateral trading system agreements. The likely work programme could include themes such as:

- Analysis of trade policy and market access issues of particular interest to developing countries.

- Special and differential treatment as a means for managing developing countries' transition to full implementation of multilateral rules. 
- Policies and practices to strengthen government institutional capacities and to enhance supply-side (enterprise) responses to trade opportunities. A set of good practices for demand-led, locally owned initiatives is envisaged for December 2000.

\section{Untying official development assistance (ODA)}

In 1998, OECD Ministers and the Birmingham G8 Summit welcomed agreement in the DAC to work towards a Recommendation to untie aid to the least developed countries. The Recommendation has the objectives of fostering effective partnership, strengthening developing country ownership and responsibility, increasing aid effectiveness and value for money, and promoting the integration of developing countries into the global economy. DAC Members have reached agreement on many provisions of the Recommendation, including most of the ODA activities to be covered and the provisions to ensure transparency and a level playing field. However, the 1999 DAC High-Level Meeting was unable to reach full consensus, particularly in relation to:

- The coverage of investment-related technical cooperation and food aid.

- Provisions to address the concerns of some Members that untying aid might result in declining aid flows.

- Steps to ensure equitable burden-sharing among donors in their efforts to implement a Recommendation.

Nevertheless, DAC Members are committed to continue to work towards a Recommendation, a goal supported in 1999 by OECD Ministers and the Cologne G8 Summit. At the 1999 DAC Senior-Level Meeting, a large majority of DAC Members agreed on a basis for a Recommendation, but considerable efforts are still required to address satisfactorily the concerns of remaining Members in order to reach consensus at the May 2000 DAC High-Level Meeting.

\section{Mobilising and monitoring resources for development}

\section{Development finance}

A series of three workshops jointly sponsored by the DAC and the World Bank underlined the importance of private sector-led growth. The workshops focused on three areas: Meeting Infrastructure Needs into the 21 st century (1998); Financial Systems for Sustainable Resource Mobilisation in Less Advanced Developing Countries (1999), and Enterprise Development for Private Sector-Led Growth (January 2000). Guidelines are now being elaborated covering these areas. Related work has also begun jointly with the World Bank, the OECD Development Centre and others on broader development finance issues. Development finance will be a major topic for the 2000 DAC High-Level Meeting.

\section{External indebtedness}

The international financial crisis heightened demand for more timely and transparent data on external borrowing and foreign exchange reserves. The OECD, the Bank for International Settlements, the International Monetary Fund and the World Bank have combined the various data series they collect to produce quarterly advance indicators of indebtedness. These data, assembled by the OECD, were published for the first time in 1999, and are being updated quarterly. Indicators of each country's borrowing from the private sector and its stock of reserves are presented, together with a description of the series. 


\section{DAC statistics online}

(www.oecd.org/dac/htm/online.htm)

\section{and in electronic format}

The unique statistical series produced by the DAC are now accessible online. Tables can be built dynamically by selecting any combination of years, donors, recipients, type of finance and sector. Data can also be presented graphically and downloaded. Country and sector totals can be displayed for standard groupings or according to the user's own criteria. Statistics of external debt as well as reference series of GNP and population are also available. Access is available on a subscription basis. A new CD-ROM to be published early in 2000 will make available data on aggregate financial flows, debt, and individual project commitments in an economical, integrated format.

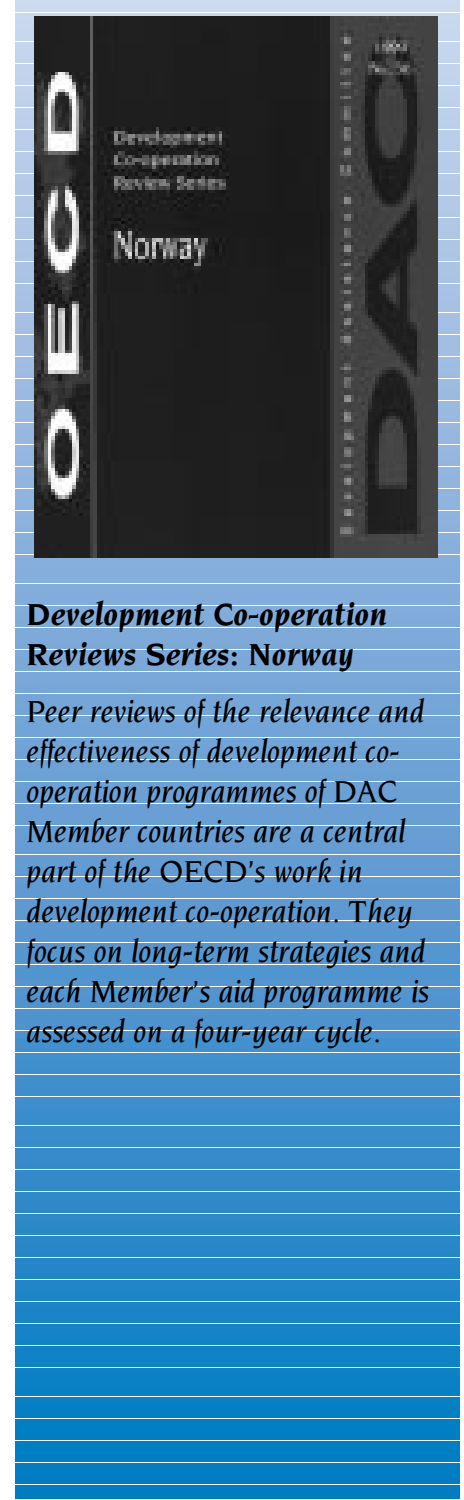




\section{DEVELOPMENTAL POLICY COHERENCE}

The development process can advance more rapidly than ever before in the new global economy. But, while opening their economies to trade and investment is a necessary condition for developing countries to achieve sustained high growth and reduce poverty, it is by no means a sufficient condition.

- Initiating sustainable dynamic growth requires: sound market-oriented economic policies; appropriate social policy frameworks, including strong investment in human capital and adequate social safety nets; and good governance. As shown by the Asian financial crisis, weaknesses in any of these basic foundations make even successful developing economies vulnerable.

- At the same time, OECD countries have a pivotal role to play by improving their developmental policy coherence. This means consciously taking account of the needs and interests of developing countries so that they become effective, rather than marginal, players in the global economy. OECD countries can promote developmental policy coherence by: strengthening the framework for international trade and capital flows; reconciling the environment with trade and investment and development; facilitating participation of developing countries in the global information society; and enhancing the coherence of development co-operation policies.

These were the central findings of the report submitted to Ministers at their meeting in 1999 on the links between trade and investment and development, and the role that the OECD might play in promoting greater policy coherence, subsequently published under the title Policy Coherence Matters.

Experience shows that a number of tools and mechanisms can be effective in taking into account the development dimension in overall policy-making in OECD countries. These include: a common vision for articulating and evaluating policies; an effective framework of interministerial co-ordination within capitals; research and analytical capacities to support efforts to improve the developmental coherence of policies; and mechanisms for consultation with civil society to promote consensus-building in society on specific policy issues. Moreover, international co-operation can also play an important role.

Thus, in response to this report, at their meeting in May 1999, OECD Ministers agreed that:

- Greater coherence in OECD countries' policies is essential to the achievement of the international development targets of the OECD development partnerships strategy.

- They will continue to work together at the OECD to take greater account of the impact of their policy frameworks on developing countries.

- The OECD should undertake further analytical work on policy coherence, and report on this work. 


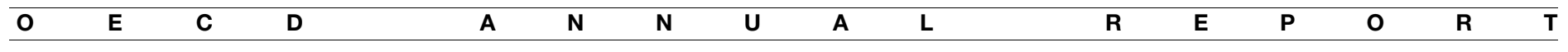

The Organisation is currently working with its Member countries to enhance the coherence of their policies for the sustainable development of nonOECD economies, through its peer review processes, a major DAC project to produce a checklist on policy coherence as part of its work on poverty reduction, involving multidisciplinary analytical work, and an increasingly integrated approach to work on trade and development. These efforts are aimed at helping to ensure both greater policy coherence across different policy areas in OECD Member countries, and greater coherence across OECD countries in each policy area.

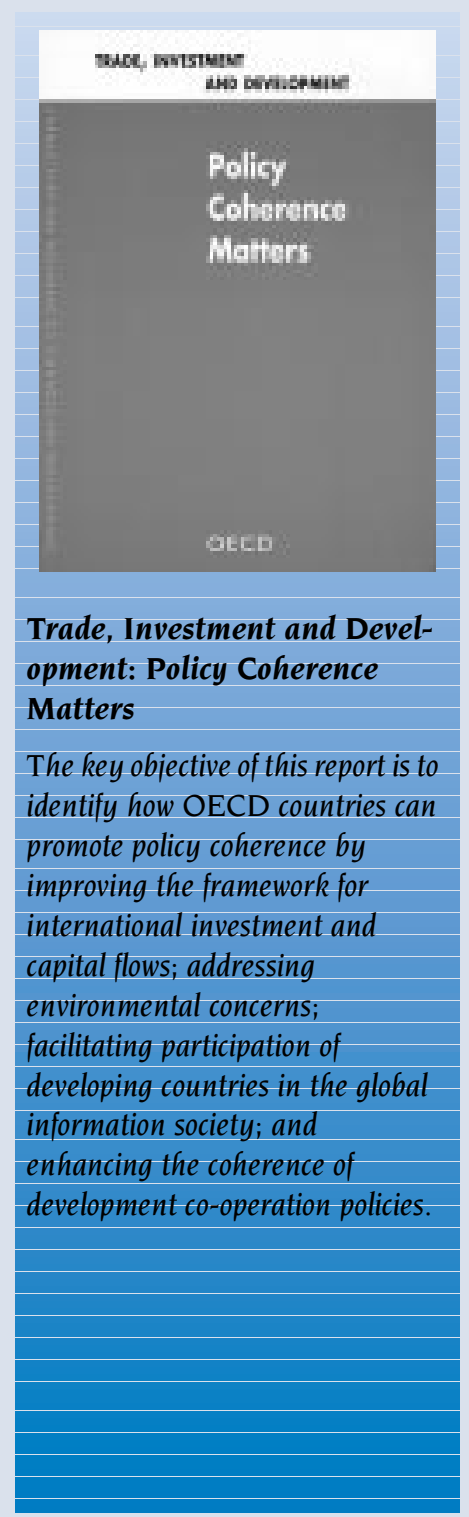




\section{THE DEVELOPMENT CENTRE}

www.oecd.org/dev/

The Development Centre undertakes comparative development analysis and policy dialogue. The need for a genuine and credible development dimension in the policy dialogues carried out under OECD auspices has increased, particularly given the greater diversity in Members and the need to take into account developments in important countries beyond current membership. In a world where the benefits of globalisation are perceived to be tilted towards the developed countries, the Centre serves as a bridge-builder with countries with which co-operation is not yet fully established and as a ground-breaker on issues which are not yet ripe for policy dialogue.

In 1999, the Centre began work on its biennial 19992000 work programme, entitled The Sustainability of Economic Policy Reform and revised it due to the departure of a major contributor. The revised programme is based on two key ideas: that sustained development in the global economy requires good governance; and that policy reform must be accompanied by attention to its impact on poverty, inequality and social cohesion.

The Centre's margin of flexibility allows it to react swiftly to emerging policy issues. In advance of the WTO talks in Seattle (December 1999), a policy brief was written and published on Multilateral Tariff Liberalisation and the Developing Countries (Policy Brief no. 18); this Brief was cited on several occasions by both top negotiators and the media during the meeting. The Centre's work programme for 2000 has been updated to include analysis on the millennium round and developing countries.
In the aftermath of the emerging market crises, the importance of establishing a stable and sustainable global financial system was addressed jointly with policymakers from Asia, Latin America and OECD countries at the Development Centre/Asian Development Bank Forum in June and at the Development Centre/InterAmerican Development Bank Forum in November.

\section{Research activities}

The Centre's 1999 research activities were grouped under four headings: Financial Crises and Structural Implications; Implementation of the Development Partnerships Strategy; Sustainable Development; and Globalisation, Social Cohesion and Demography. Each heading covers a set of policy issues with a high priority on the agendas of policy-makers.

Research on financial crises and structural implications focused on:

- The design and implementation of a policy framework that allows recipient countries to benefit from global capital mobility without compromising macroeconomic and financial stability.

- A reappraisal of the legal, regulatory and institutional constraints that condition the performance of the private sector in developing countries and emerging economies.

Activities related to the implementation of the Development Partnerships Strategy examined:

- How institutional and policy reform can enhance the effectiveness of education and health services 
in reducing poverty as well as the efficiency of education and health spending with respect to primary education and basic health outcomes.

- The economic and political conditions necessary for reforms which target improvements in governance and the institutional arrangements which would facilitate their implementation.

- The set of policy measures necessary for successful and sustained take-off in African countries and the scope for increased intra-regional trade in sub-Saharan Africa in connection with the higher growth prospects of emerging economies.

Work on sustainable development and globalisation, social cohesion and demography included assessments of:

- The potential gains for major developing countries from making binding commitments to control greenhouse gas emissions.

- Which economic and social polices will ensure a more sustainable and equitable distribution of the economic gains from globalisation.

\section{Policy dialogue and publications}

A key feature of the Development Centre's work is dialogue with policy-makers in OECD and developing countries in the form of seminars, forums and conferences. Policy-dialogue meetings for 1999 included the joint Seminar with the Chinese Academy of Social Sciences and the Government of Yunnan Province, China in the 21 st century: Challenges of Global and National Economic Integration, and the International Conference, Fighting Corruption in Developing Countries and Emerging Economies: the Role of the Private Sector, organised in collaboration with four external partners and 12 sponsors and held in Washington, D.C. An experts meeting was organised in Cairo with the World Bank and the Economic Research Forum to discuss the Dynamics of the New Regionalism in the Middle East and North Africa (MENA).

In addition to the regular meetings held in partnership with the Asian Development Bank and the Inter-American Development Bank mentioned above, a third regional meeting was launched in 1999 in co-operation with the African Development Bank, The first International Forum on African Perspectives, (February 2000). Notable among the Development Centre's publications in 1999 were: Conflict and Growth in Africa: Volumes 1, 2 and 3; Participatory Governance, the Missing Link for Poverty Reduction (Policy Brief no. 17) and Multilateral Tariff Liberalisation and the Developing Countries (Policy Brief no. 18, cited above).

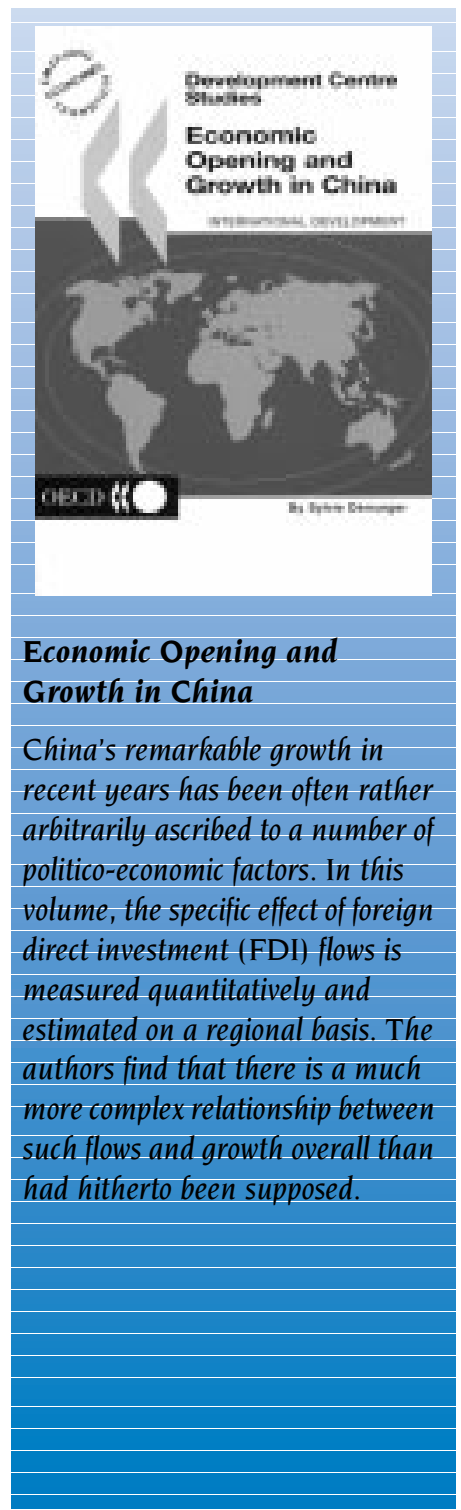




\section{CLUB DU SAHEL}

www.oecd.org/sah/

The international community discovered the Sahel almost 25 years ago, as a result of the great drought of 1973-1974. The Club du Sahel was established in 1977 to facilitate co-operation among aid donors and between them and the countries of the region. Since then, northern perceptions of the Sahel have remained largely unchanged. The caricature of a drought-ridden region, devastated by natural disaster with starving populations continues to influence decision-making. Traditional aid instruments still dominate northern development co-operation practices. The profound socio-economic and political changes that have taken place over the last decade in the region are largely ignored.

As the institutional capacity of the Club's Sahelien partners has improved - along with the rising influence of civil society in the Sahel - the Club's framework and its working methods have also evolved. During 1999, the Club du Sahel Secretariat re-examined its working methods with its regional partners, Members, and Sahelien actors. It also sought to reinforce its synergies with the various fora and institutions which work in the Sahel, West Africa and pan-Africa.

The September conference at Yverdon-les-Bains in Switzerland launched a new phase in the life of the Club du Sahel, with Club Members sharing the Secretariat's determination to take on concrete reforms of aid practices in the field. With the Secretariat's support, 2000 will be decisive for translating the Members' political determination into real change.

\section{Reforming development co-operation policy and practices}

The 1999-2000 work programme takes up two challenges. The first is to produce an overview of the system of aid to the Sahel and support the efforts of countries like Mali that are making their first attempts to bring the aid system under control. During 1999 the Club's overall work programme was reshaped to take better into account the relevant initiatives of other international bodies such as the Development Assistance Committee, the Special Programme of Assistance for Africa and the Global Coalition for Africa. Technical components of the programme are in the course of execution. The second part of the programme aims to move from diagnosing aid problems to finding solutions, especially in the areas of instruments and procedures.

\section{Sustainable rural development}

The rural development programme is scheduled to end its present cycle in 2000 with the Permanent InterState Committee for Drought Control in the Sahel, (usually referred to by its French initials, CILSS) assuming leadership. Three types of activity were organized in 1999 under this programme: the organisation of the Food Crisis Prevention Network; discussions on the environment; the implementation of the Convention to Combat Desertification (CCD) and assistance in defining and implementing national policies in the rural sector. 


\section{Support for local and regional development strategies}

After almost three years of work on a methodology for assessing local economies and ways to transfer it to Africa, the Club Secretariat will from 2000 focus its energy on organising debates among partners on local and regional development strategies.

At the local level, the Municipal Development Programme (MDP) and the Club Secretariat will support development of strategies to promote a number of economic activities. By end-2000, there should be "lessons learned" about how to debate local issues, both urban and rural. At the regional level, mayors from Sikasso (Mali), Korhogo (Ivory Coast) and Bobo Dioulasso (Burkina) are well aware of the regional dimension of local issues highlighted in the ECOLOC exercises.

Lastly, systems to facilitate decision-making on regional entities - which will play a vital role in the economic and political change process over the coming decades - need to be established. This level is critical for influencing relations between urban and rural areas. The MDP has already agreed to respond to the need identified by mayors' associations in specific regions of Côte d'Ivoire and Senegal. The two regions are mobilising funding and the Club Secretariat has agreed to provide technical support

\section{Integrating the Sahel into Africa and the world}

As clearly shown by earlier diagnoses, it is mainly West Africa's economic operators and ordinary people who put integration into action, while national institutions and donors often find it hard to fit their activities into a regional framework. From this point of view, the study launched in 1998 and finished at the beginning of 1999, provided interesting results. Preliminary contacts with Ghana and Côte d'Ivoire could provide the basis of a cross-border initiative in West Africa to follow the model already implemented in East Africa. The followup of this proposal will be pursued during 2000 .

\section{Supporting African private sector development}

A series of studies on the private sector initiated by the Club Secretariat in the late 1980s and the creation in 1993 of the West African Enterprise Network (WAEN), led to the design of the African Private Sector Support Programme in 1994. The aim was to support enterprise networks at the country and at regional level, to develop business activity and investment, promote the creation of modern small and medium-sized enterprises, and improve the national and regional business environment. In 1998, a group of aid agencies mobilised to help the West African Enterprise Network move towards financial autonomy, and develop other networks in sub-Saharan Africa. The first year of this second phase (June 1998 - June 1999) saw some successes (progress with the autonomy of the West African Network, creation of the East and Southern African networks), but also a number of major management difficulties. A new programme launched under the aegis of the Club Secretariat integrates greater transparency and real partnership, replacing the "technical assistance" approach with one that responds to requests of the three networks. External support provided via the Private Sector Support Programme is limited to some 30 months, at the end of which the programme will be completely African-managed and located in Africa. 


\title{
INTERNATIONAL FUTURES PROGRAMME
}

\author{
www.oecd.org/sge/au/
}

The central role of the Advisory Unit to the SecretaryGeneral is the identification and evaluation of newly emerging issues. It manages the OECD International Futures Programme which was set up to promote strategic thinking, test new ideas and stimulate dialogue between government, business and research on matters of long term. Today's decision-makers face a complex and uncertain world in which the assessment of the trends shaping our long-term future has become a formidable challenge. Economic, social and technological forces are combining to drive change at great speed and in sometimes unexpected directions. A deluge of information is making it increasingly difficult to discern the key factors affecting the long term.

The International Futures Programme is designed to help decision-makers inside and outside government to come to grips with this challenge. The Programme offers a unique set of features: improved monitoring of the long-term economic and social horizon, with early warning on emerging domestic and international issues; more accurate pinpointing of major developments and possible trend breaks; greater analytical appreciation of key long-term issues; and better dialogue and information-sharing to help set policy agendas and map strategy. All of this is backed up by the OECD's unique experience and capacity for in-depth analysis across a wide range of policy areas of keen interest to governments.

Established in 1990, the Programme is only partially financed through the budget of the Organisation. A major part of its funding is based on voluntary contributions from governments of OECD Member countries and on grants from enterprises and foundations. Private sector participation in the Programme includes major international companies from a range of key sectors, for instance insurance and financial institutions (Allianz, AIG, Banamex, Bancomext, Barclays, HypoVereinsbank, ING, Zurich), the agro-food sector (Coca-Cola, Philip Morris, Nestlé, Unilever), the car industry (DaimlerChrysler, Koç, Toyota), the telecommunications sector (BT, Ericsson, Siemens), biotechnologies (Novartis, Pulsar, SmithKline Beecham), and energy (EDF, Mitsui, Ontario Power Generation, Statoil).

The four interrelated and mutually supportive elements of the Programme are described below.

\section{The Forum for the Future}

A key element of the Programme's activities is the Forum for the Future, which serves as a focal point for international multidisciplinary conferences and workshops on issues of long-term strategic importance. Following on from previous high-level meetings on themes related to the economy, society, major emerging regions (such as China) and sectors in rapid transition (such as the agro-food chain and energy), a further Forum conference was held in December 1999 in Berlin, Germany which focused on $21^{\text {st }}$ Century Social Dynamism. Participants discussed the long-term outlook for social change, looking in particular at the capacity of individuals and social systems to respond to the deep-seated transformations which the emerging knowledge economy and growing global integration in the next century are likely to bring. A publication 
drawing on the papers presented at the conference will be released in the summer of 2000 .

A further Forum conference on the theme $21^{\text {st }}$ Century Governance: Power in the Global Knowledge Economy and Society, held in Hanover, Germany in March 2000 looked at the trends, challenges and policies that are likely to shape the governance capacity needed to turn tomorrow's tremendous technological, economic and social possibilities into reality. This conference will result in a publication towards the end of 2000. Two books from Forum conferences appeared in 1999: Energy: The Next Fifty Years, and The Future of the Global Economy: Towards a Long Boom?

\section{OECD Futures Projects}

The Projects are focused, multidisciplinary research and policy analysis on special themes, largely as upshots from Forum for the Future conferences. The first Project examined the future of international air transport. The theme currently being explored is that of emerging systemic risks and the role of government and markets in this context, which might be implemented in the course of the year 2000 .

\section{Future trends}

An essential function of the Programme is the monitoring of future economic, social and technological developments and making this information available to policy-makers, enterprises, university institutions and the general public. The prime tool for this is the CDROM Future Trends. It is produced as a spin-off from the OECD Future Studies Information Base, a computerised information system providing abstracts of monographs, journal articles and unpublished documents selected from the literature of future studies worldwide. A fifth edition of Future Trends was released in
September 1999. In addition to around 8500 abstracts drawn from the information base, Future Trends 5 contains the full text of 11 Forum for the Future reports and other texts produced under the International Futures Programme. In 2000, it is planned to add another 1000 records to the base and to release a sixth edition of Future Trends in the fall. New marketing channels for the information base were explored in 1999. Two agreements have been reached with major European online suppliers, and others are under discussion with North American ones, which should result in further accords in the course of 2000 .

\section{Networks of long-term strategists}

The OECD International Futures Network is a global network of some 600 people in government, industry and business, and research institutions who share a common interest in long-term developments and related policy issues. Included are a host of leadingedge organisations, in particular in OECD countries. They include The Brookings Institution, Centre for Strategic and International Studies, Rand Corporation and Stanford Research Institute in North America; the International Institute for Applied Systems Analysis, Institut Français des Relations Internationales, Prognos and the Royal Institute of International Affairs in Europe; and the Japan Economic Research Institute, NIRA, Nomura Research Institute, the Korean Development Institute and the Korea Institute for International Economic Policy in Asia.

In July 1999 the Advisory Unit convened a meeting of long-term strategists drawn largely from Prime Ministers' Offices, finance ministries, line ministries, planning commissions and specially created government centres for strategic studies. This was the first time that such a gathering had been held at OECD. It served pri- 
marily as an opportunity for an exchange of views on relevant long-term future trends, and led to the decision to create a network of OECD government longterm strategists. Further meetings are planned. In January 2000 the network will come together to discuss the Europe 2010 scenarios, elaborated by the Forward Studies Unit of the European Commission, and the implications of these scenarios for OECD Member countries inside and outside the EU. In autumn a meeting is envisaged on the theme of challenges for economic and social policy in the first decades of the next century.

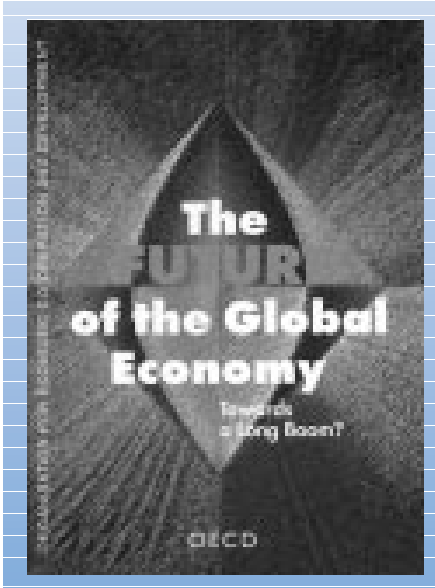

The Future of the Global Economy: Towards a Long Boom?

This book reviews the forces driving economic and social change in today's world. It assesses the likelihood of a long boom materialising in the first decades of the $21^{\text {st }}$ century and explores the strategic policies essential to make it happen.

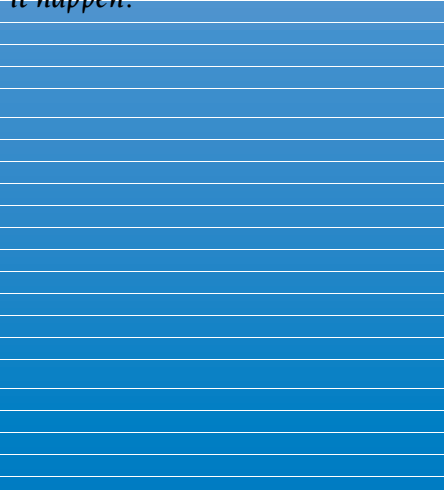




\section{INTERNATIONAL ENERGY AGENCY \\ www.iea.org/}

The International Energy Agency (IEA) is the forum for energy co-operation among 24 OECD Member countries. It maintains an emergency system for dealing with oil supply disruptions and publishes authoritative information on international energy markets. The IEA promotes rational energy policies, the development of alternative energies and increased energy efficiency. It works to strengthen the link between environment and energy policies, especially in relation to climate.

In 1999, the IEA celebrated its 25th anniversary and invited the Czech Republic to become its 25th Member country. The Czech Republic has accepted and will formally join in 2000

Meeting on the occasion of the Agency's 25th anniversary in May, Ministers reaffirmed their commitment to the Agency's work on energy security and diversity and the importance of promoting its objectives through greater and deeper relationships with non-member countries.

The IEA published in-depth reviews of the energy policies of Finland, Hungary, Ireland, Iceland, Italy, Japan and Switzerland. In the 1999 edition of its World Energy Outlook series, the IEA looked at energy subsidies in eight non-IEA countries and showed how the elimination of those subsidies could cut global $\mathrm{CO}_{2}$ emissions by as much as $4.6 \%$.

\section{Oil industry and markets}

The IEA's monthly Oil Market Report tracked the surge in oil prices from less than $\$ 10$ a barrel early in the year to more than \$25. Two mild winters helped to depress prices, but then the production restraint agreement made in March by OPEC members - and by some nonOPEC countries - reversed the trend. The agreement removed almost 4 million b/d from the market. Increased economic activity in Asia, notably in China, India and Korea, led to an oil demand recovery, while fears of supply disruptions caused by the "Y2K bug" at the end of the year also fuelled demand.

In September, the IEA welcomed Venezuelan Oil Minister Ali Rodriguez Araque to Paris. This was the first visit to the Agency by an oil minister of an OPEC country. Then in December the fifth Energy Experts meeting brought together participants from energy producers and consumers.

\section{Energy and climate change}

The Agency continued its work on practical methods to help Member countries reduce their greenhouse gas emissions from energy and meet their commitments under the Kyoto Protocol. The IEA made a substantive contribution to the UN Climate Convention process and continued to analyse domestic policies and measures in Member countries. The Agency organised a simulation of $\mathrm{CO}_{2}$ emissions trading on the Paris Stock Exchange.

Forty IEA Implementing Agreements continued to encourage collaboration in developing and deploying climate-friendly energy technology involving both Member and non-member countries. A publication, International Collaboration in Energy Technology - A Sampling of Success Stories bore witness to these efforts. The IEA continued to host the Climate Technology Initiative (CTI). 


\section{Energy diversification}

The IEA continued to analyse market reform and its implications. The publication Electricity Market Reform An IEA Handbook outlines the key aims of reform and the major issues raised as governments implement market reforms. Another study, Electric Power Technology: Opportunities and Challenges of Competition, examines how increased competition will affect power generation. In conjunction with the Nuclear Energy Agency, the IEA organised a meeting to discuss the future of nuclear power in the OECD.

\section{Relations with non-member countries}

Close co-operation with Russia continued. The IEA organised a well-attended seminar in Moscow on the requirements of investors. An IEA seminar on Caspian oil and gas was held in Paris. The Agency organised a conference in Beijing on the natural gas industry in China, with two-thirds of the 200 participants coming from China, and workshops on electricity and gas in Brazil and on gas in Mexico. Work was initiated under a bilateral co-operation agreement with the Indian government, examining energy indicators, diversification and environmental issues.

\section{Y2K}

The IEA worked throughout the year to minimise the possible risk of disruptions to oil supplies caused by the millennium computer date change. Seminars were held in Abu Dhabi, Caracas, Moscow, Prague and Singapore to increase awareness of the possible risks. A simulation exercise of possible Y2K disruptions in the energy sector was held in September. The Agency was ready for action, if required, at the end of the year. 


\section{NUCLEAR ENERGY AGENCY www.nea.fr/}

During 1999, the Nuclear Energy Agency (NEA) adopted a new Strategic Plan providing a road map for the Agency over the next five years. The road map will support NEA's mission of assisting its Member countries to maintain and further develop, through international cooperation, the scientific, technological and legal bases required for safe, environmentally friendly and economical use of nuclear energy for peaceful purposes. The plan also aims at strengthening the NEA's role as a forum for exchanging information and experience, as a centre of nuclear competence, and as a contributor to nuclear policy analyses, particularly relating to energy and the environment.

In view of serious budgetary limitations affecting national nuclear research activities, international pooling of efforts is needed to ensure maintenance of the underlying knowledge base and scientific infrastructure in this field. To meet these needs, the NEA has continued its key functions of organising and co-ordinating autonomous co-operative projects and pooling resources with a view to addressing technical and scientific challenges of common interest to its Members.

\section{Nuclear development and the fuel cycle}

In 1999 about 24\% of the OECD area's electricity supply was generated by nuclear power plants, but this share is expected to decline slightly over the next decade or two owing to plant retirements in Europe and North America that will not be compensated fully by new connections to the grid. In this context, the NEA convened jointly with the International Energy Agency (IEA) an international meeting to discuss issues related to the future of nuclear power and their implications for energy supply security and the environment. The proceedings of the meeting, entitled Business as Usual and Nuclear Power, were published early in 2000 .

Several new reports in the field of nuclear development and the fuel cycle were published over the past year, including: the 1999 update of OECD Nuclear Energy Data; a report on Environmental Activities in Uranium Mining and Milling; a multilingual Glossary of Nuclear Power Plant Ageing; a review of Methodologies for Assessing the Economic Consequences of Nuclear Reactor Accidents; and a status and assessment report on Actinide and Fission Product Partitioning and Transmutation. The proceedings of the 1998 workshop on the Back-End of the Fuel Cycle in a 1000 GWe Nuclear Scenario, held in Avignon (France), were also published.

Within the framework of horizontal activities under way within the OECD, the NEA contributed information and data on nuclear energy for an interim report on sustainable development, and undertook the preparation of a background document on nuclear energy from a sustainable development perspective, intended for the OECD Ministerial meeting of 2001. The NEA was represented at the 5th meeting of the Parties to the Framework Convention on Climate Change, held in Bonn, and continued to publish on its Internet site and in technical literature results from its studies on the role of nuclear power in alleviating the risks of climate change.

\section{Nuclear safety and regulation}

Several important issues concerning reactor safety and regulation need continuing attention: human and 
organisational aspects in reactor operation; ageing of materials; the use of probabilistic techniques; prevention of accidents; and maintenance of a suitable level of competence and research capabilities in the longer term. Approximately 40 technical reports were prepared and disseminated on these topics.

Following a study on nuclear safety research facilities suitable for internationally funded co-operation, the NEA launched several projects in the technical areas of nuclear fuel, thermal hydraulic behaviour of the reactor coolant system, and severe accidents.

Considerable effort was devoted during the year to help Member countries prevent Y2K-related problems in nuclear installations. In particular, the NEA set up a world-wide information system - the Y2K Early Warning System (YEWS) - which provided an up-to-date account of the status of nuclear installations during the transition into the new millennium. Some 300 nuclear facilities in 29 countries provided and received information through the YEWS system, with most exchanges occurring within 20 to 30 minutes of the beginning of the new year.

In the area of nuclear safety regulation, the NEA dealt with several issues of particular importance, including regulatory effectiveness, early identification of signs of declining safety performance, maintaining safety in a deregulated electricity market and safety culture.

\section{Radiation protection}

By the end of the millennium, important milestones were reached in the NEA radiation protection programmes. The second series of international nuclear emergency exercises, INEX 2, was completed, and lessons learned from the four INEX 2 exercises were analysed. Plans were laid to address identified issues in future INEX exercises. Participation in the Information System on Occupational Exposure (ISOE), which col- lects information on annual worker exposure in commercial power reactors, grew to 390 operating units ( $90 \%$ of the world's total) and 39 reactors in cold shutdown or decommissioning. ISOE includes reactors in 28 countries, 11 of which are not members of the NEA.

The future evolution of the internationally accepted system of radiation protection, emphasising transparency and coherency aspects and focusing on stakeholder involvement in the decision-making process, was discussed from a policy point of view. A report comparing the assessment and management of risks from radiation, chemicals and asbestos complemented these discussions.

In the coming year the NEA radiation protection programme will focus on emerging and forward-looking issues. Strategies on nuclear plant decommissioning, from a radiation safety perspective, will be studied, as will some of the more detailed aspects of the system of radiation protection in order to assist its evolution. The implementation of the long-term strategy of the INEX programme will begin, and continued expansion of the ISOE programme will be pursued.

\section{Radioactive waste management}

In an effort to improve co-ordination of safety assessment techniques, site evaluation, and engineering towards a common "safety case" for managing nuclear waste, work orientations of the NEA provide for the integration of these various aspects of the safety case in geologic disposal. A new study, Geologic Disposal of Radioactive Waste: Review of Developments in the Last Decade, has highlighted the growing importance of confidence-building and a step-wise decision-making process in geologic disposal. These issues have also been addressed in a concise report, Confidence in the Long-term Safety of Deep Geological Repositories, which elaborates the 
basic ideas of the safety case approach and stresses the need to develop and communicate the confidence of the different parties involved. At the request of the United Kingdom, Sweden and Japan, the NEA organised international peer reviews of major studies in their national radioactive waste disposal programmes.

The NEA Co-operative Project on Decommissioning of Nuclear Installations, which benefits from some 15 years of experience and now includes 38 decommissioning projects, has been extended for another fiveyear period to 2005. Given the growing importance of decommissioning, a workshop on regulatory aspects was organised in Rome, Italy in May 1999.

Both policy-related as well as technical issues will remain high on the agenda for future NEA work on radioactive waste management. The year 2000 will see the publication of an important report on retrievability of waste in geologic disposal, aimed at providing guidance to Member countries on policy-making in this area. In the technical field, a series of five highly visible workshops will be held, marking a major milestone in the assessment of underground transport of radionuclides from radioactive waste repository sites.

\section{Nuclear science}

The NEA nuclear science programme is geared to helping Member countries maintain and develop the quality of scientific expertise necessary to solve current technological issues and support longer term development of nuclear energy. The programme continued to develop its traditional competence in nuclear criticality safety and reactor and fuel cycle physics, in parallel with studies of more advanced and innovative concepts in areas such as nuclear fuel cycle chemistry and accelerator-driven transmutation. Special attention will be given during 2000 to identifying areas of highest priority for preserving and developing the necessary scientific infrastructure and to locating valuable experimental information in need of safeguarding.

\section{Data Bank}

The NEA Data Bank plays the role of a national nuclear data and computer programme centre for most NEA countries, and as such provides a direct service to scientists in those countries. Close to 2500 registered users, with individual passwords, can directly access internationally validated scientific nuclear data, computer programmes and chemical thermodynamic data. Users accessed the online databases containing scientific nuclear data more than 20000 times during 1999, and some 2000 computer programmes, covering all areas of nuclear applications, were distributed on request. The Thermochemical Database (TDB) project, which is intended to provide recommended chemical thermodynamic data mainly for use in the safety assessment of nuclear waste repositories, is conducted in close cooperation with the NEA radioactive waste management programme. The main users of the Data Bank services are national laboratories (50\%), nuclear industry, vendors and utilities (25\%) and universities (25\%).

The Data Bank has started to compile integral experimental nuclear data in specific areas related to reactor and fuel cycle physics. These data are extremely important for the validation of the predictive capacity of a computer programme in a specific nuclear application. The interest in these data in Member countries is increasing. Close to 3000 data sets were requested from the Data Bank in 1999, compared with about 1000 in 1998.

\section{Legal affairs}

The NEA is the main international forum for study of the nuclear liability regime, focusing particularly on the 
modernisation of the existing civil liability conventions and those providing for supplementary compensation for nuclear damage out of public funds. In this respect, the Contracting Parties to the 1960 Paris Convention on Third Party Liability in the Field of Nuclear Energy, of which the OECD is the depository, have launched an extensive revision of this instrument. In 1999 they also decided to undertake the revision of the 1963 Brussels Convention, which supplements the Paris Convention with a mechanism of international financial solidarity in the case of a severe nuclear accident. Highest priority will continue to be given to these activities in 2000 .

As part of its work on the dissemination of information on nuclear law, the NEA published a new update of its study entitled Regulatory and Institutional Framework for Nuclear Activities in OECD Member Countries. It also continued the publication of the Nuclear Law Bulletin, which constitutes the major source of information in this field world-wide.

\section{Relations with non-member countries}

As part of the programme of co-operation with non-members, the NEA conducted an international review of the Russian MINATOM Nuclear Safety Research Strategic Plan. This review resulted in a number of recommendations regarding the overall focus of the Plan, as well as specific technical areas.

The RASPLAV project - a large experimental joint project conducted in Russia and sponsored by the NEA - included in 1999 a large-scale test aimed at providing a better understanding of the possible consequences of the overheating of the reactor pressure vessel as a result of a severe accident. This test provided data that will be useful to devise or confirm emergency procedures used in nuclear power plants.

\section{Public information and publications}

The Agency continued publishing a wide variety of scientific and technical reports reflecting the full scope of its activities. Among the best-sellers in 1999 were: Advanced Reactors with Innovative Fuels; OECD Nuclear Energy Data; and Use of Hydrogeochemical Information in Testing Groundwater Flow Models.

Based on its newly adopted Strategic Plan, the NEA will now develop more policyoriented papers to meet increasing demand from a wide variety of stakeholders. They will be made available on the Agency's Internet site.

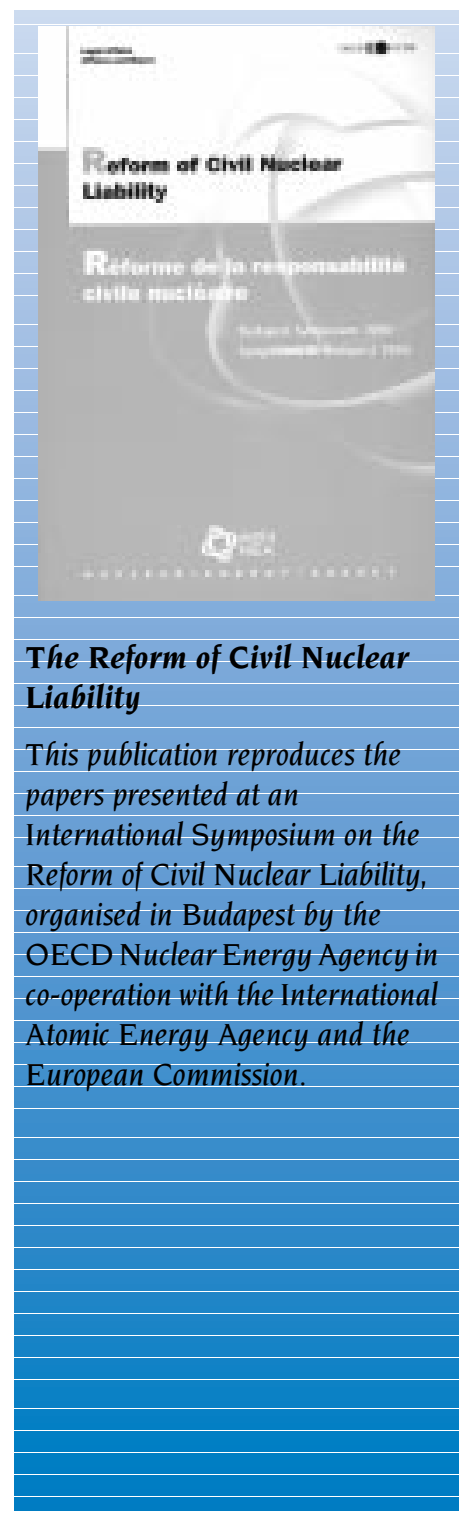




\section{EXECUTIVE DIRECTORATE}

\section{Reform}

An extensive and far-reaching reform programme has been under way in the OECD since 1996, accompanied by major budget reductions. The guiding principles of reform are responsiveness to Member country needs, holding the Organisation accountable for achieving high-quality results, ensuring maximum efficiency and cost effectiveness and a commitment on the part of the Secretariat to professional and managerial excellence. Although reform is ongoing, it has already produced a leaner and more cost-effective structure, overseen by a management that is better co-ordinated and more accountable.

Undertaking such reforms with a shrinking resources base has been a singular challenge. The Organisation experienced a $10 \%$ overall budgetary reduction for the period 1996-1999, corresponding to a cut of $18 \%$ in real terms.

In addition to co-ordinating the programme of reform, the Executive Director managed four services in 1999: Human Resources, Operations, Information Technology and Network Services, and the Language and Conference Service. Budget and Finance reported to a Deputy Secretary-General in 1999. It will be transferred back to the Executive Directorate in the spring of 2000.

\section{Human Resource Management www.oecd.org/hrm/}

Human Resource Management (HRM) is responsible for implementing and consolidating human resource functions and policies, as well as providing staff and managers with high standard administrative, medical, training, recruitment and counselling services. HRM's main achievements in 1999 and priority activities for 2000 include:

- Adoption of a new employment policy in July 1999. Full implementation will be achieved by the end of 2000.

- Implementation of a revised performance management system, accompanied by intensive training for managers. In parallel, the first OECD Competency Guidebook was produced to assist in the identification of personal development needs.

- A review of the OECD's remuneration strategy and practices which will lead to reform proposals by the end of 2000 .

- An in-depth review of the Organisation's Staff Rules begun in 1999, as part of a three-year project. Approximately one third of existing rules will be revised by end 2000 . The goal is to provide a more coherent and simplified framework for management and a simplified set of rules for staff.

- Introduction of new recruitment processes in 1999 to be followed up in 2000 .

- New medical services and preventive care programmes introduced in 1999, which will be extended and developed in 2000. 
- In 2000, a comprehensive training strategy with strong emphasis on management training and competency development.

\section{Budget and Finance}

The Budget and Finance Service staffs the programme and budget exercise, including preparation, examination by the Budget Committee and Council consideration. The programme and budget process is subject to continuous improvement. The Service is responsible for their implementation.

The Budget and Finance Service also provides financial and budgetary planning and analysis, financial systems, treasury and accounting services to the Organisation. It supplies information and guidance to other parts of the OECD to aid financial management and the execution of the budget. The Service is also undertaking a reform programme to improve its capabilities and effectiveness in all areas of its responsibility. Recent examples of major achievements include implementation of a new financial management system, automation of additional financial procedures and introduction of a new facility for tracking costs by operating unit ("directorates"), activities and projects. A new chart of accounts has been implemented and work to reform the Organisation's financial statements has begun.

\section{Operations Service}

Operations Service (OPS) is responsible for managing the infrastructure of the headquarters site and for providing a wide range of related services to support the daily functioning of the Organisation. The main activities of the Service encompass Facilities Management, Documentation Resources, and Safety and Assistance. The ageing buildings and technical installations, the geographical dispersion of annexes where $41 \%$ of staff are located and the particular problems of asbestos and fire safety, all create a difficult operational environment. Budgets have been reduced further and although there have been continued gains in efficiency and quality of services in 1999, progress is now limited by the inherent inefficiencies of the site. Throughout 1999, the service worked for a decision on the headquarters site strategy and completed several siterelated technical studies.

Efforts have continued to improve the present site and quality of services provided to the Organisation. Some examples of projects carried out in 1999 are:

- Completion of short-term action on asbestos management.

- Upgrading site surveillance.

- Connecting the latest generation of copier-printers to the computer network.

- Improvements in the quality of services such as cleaning, waste recovery, restaurants and convenience shopping.

- Renovation of the Centre for Documentation and Information, and installation of enhanced online services.

- Automation of records management and correspondence tracking in key administrative areas.

\section{Information Technology and Network Services}

The mission of Information Technology and Network Services (ITN) is to advise on and provide information systems and services that address the day-to-day needs and advance the medium-term strategic objectives of the Organisation. In addition to ensuring a secure, stable and productive IT environment for Secre- 
tariat staff to carry out their daily work, ITN's major achievements in 1999 include:

- Successfully guiding the transition to year 2000 of the Organisation's computing and communications facilities: all centrally-managed software and IT systems were verified and, where necessary, upgraded for Y2K compatibility before the cut-over.

- Consolidating statistical and analytical tools crucial to the work of the Secretariat, and implementing a new enterprise office system.

- Introducing the key elements of a new financial management system for the Organisation and budget management tools for Directorates.

- Doubling to 5000 the number of Member country government officials with direct electronic access to OECD resources through OLISnet.

- Increasing the use of videoconferencing facilities.

\section{Language and Conference Service}

The Language and Conference Service (LCS) manages the Organisation's shared operational resources in translation, interpretation and conference logistics, and provides management support in a wide range of areas. 1999 achievements and 2000 challenges for LCS may be summarised as follows:

- Over 4000 half-day sessions interpreted at Headquarters and on mission, including three meetings at ministerial level.

- Over 75000 standard pages translated. Restructuring of French translation section, with creation of quality manager and flow-manager posts.

- Development of a pilot project to manage translation requests, generate production statistics, and automate billing.

- Publication of new agriculture and economics glossaries.

- Major projects under way on document length and readability, document life cycle, new conference strategy and use of both official languages in the Organisation.

\section{PROGRAMME OF WORK AND BUDGET}

The OECD's Programme of Work and Budget is the basic charter of the Organisation's activities, staffing and financing. It is normally approved at the end of each year by the governing body, the Council, and covers the subsequent calendar year.

The consolidated OECD budget amounted to FF 1.2 billion in 1999. "Consolidated" means that the total includes both activities funded by all 29 Member countries (referred to as Part I activities or programmes and accounting for about $80 \%$ of the consolidated bud- get), plus other activities funded by groups of Member countries (referred to as Part II activities or programmes). Staff costs account for about $75 \%$ of the Part I budget. The OECD's 29 Member countries fund the budget for Part I programmes. Their contributions to the budget are based essentially on the relative size of their economies. Individual country contributions represent between $0.1 \%$ and $25 \%$ of the total budget. Part II programmes are funded according to agreements among the participating countries. 
Spiralling pension liabilities represent a growing risk to the financing of the OECD's programme of work. A solution is needed that will bring greater stability and predictability to the Organisation's finances. Considerable progress was made in 1999 toward devising such a solution, and it is anticipated that further headway will be made in 2000 .

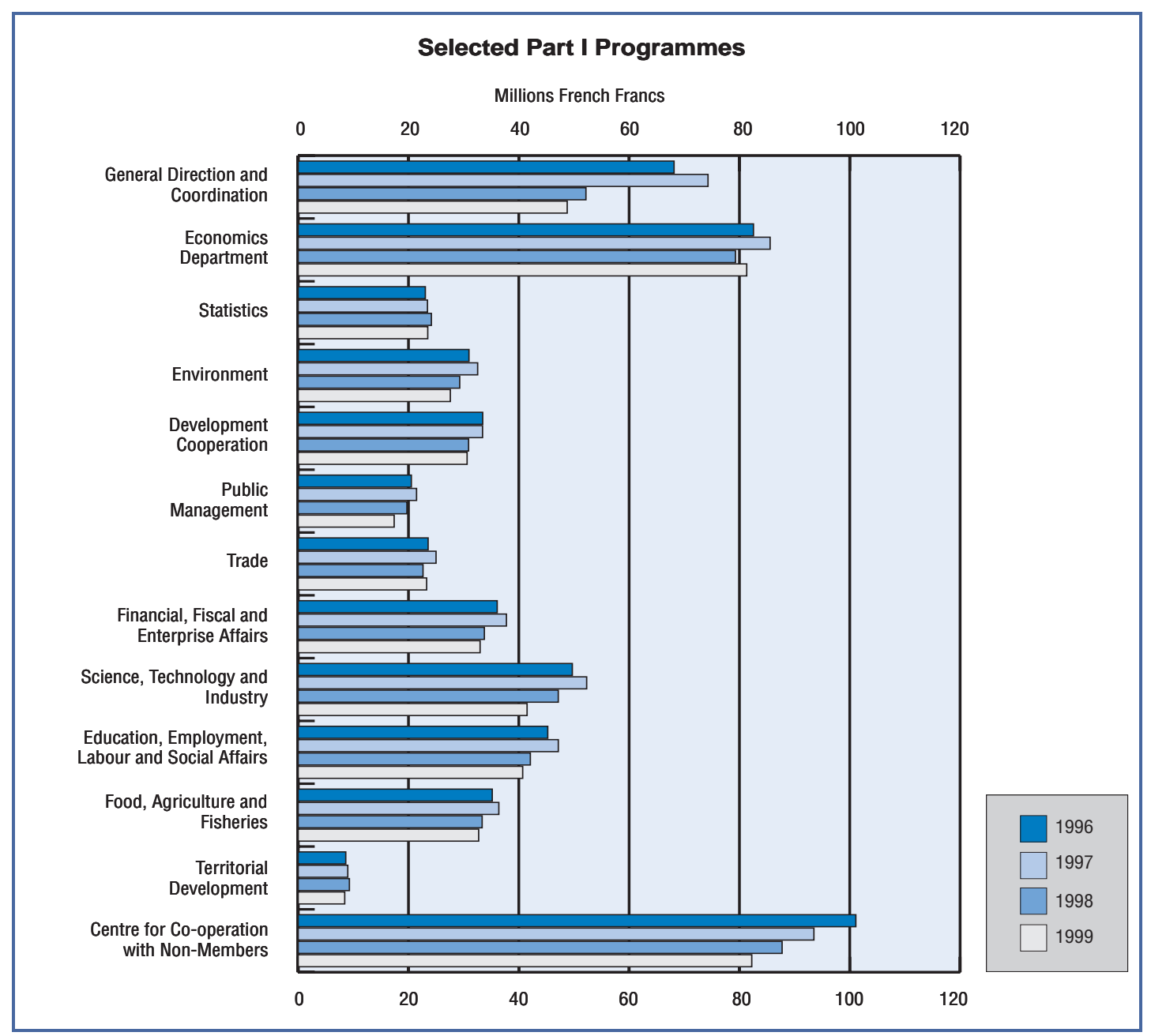




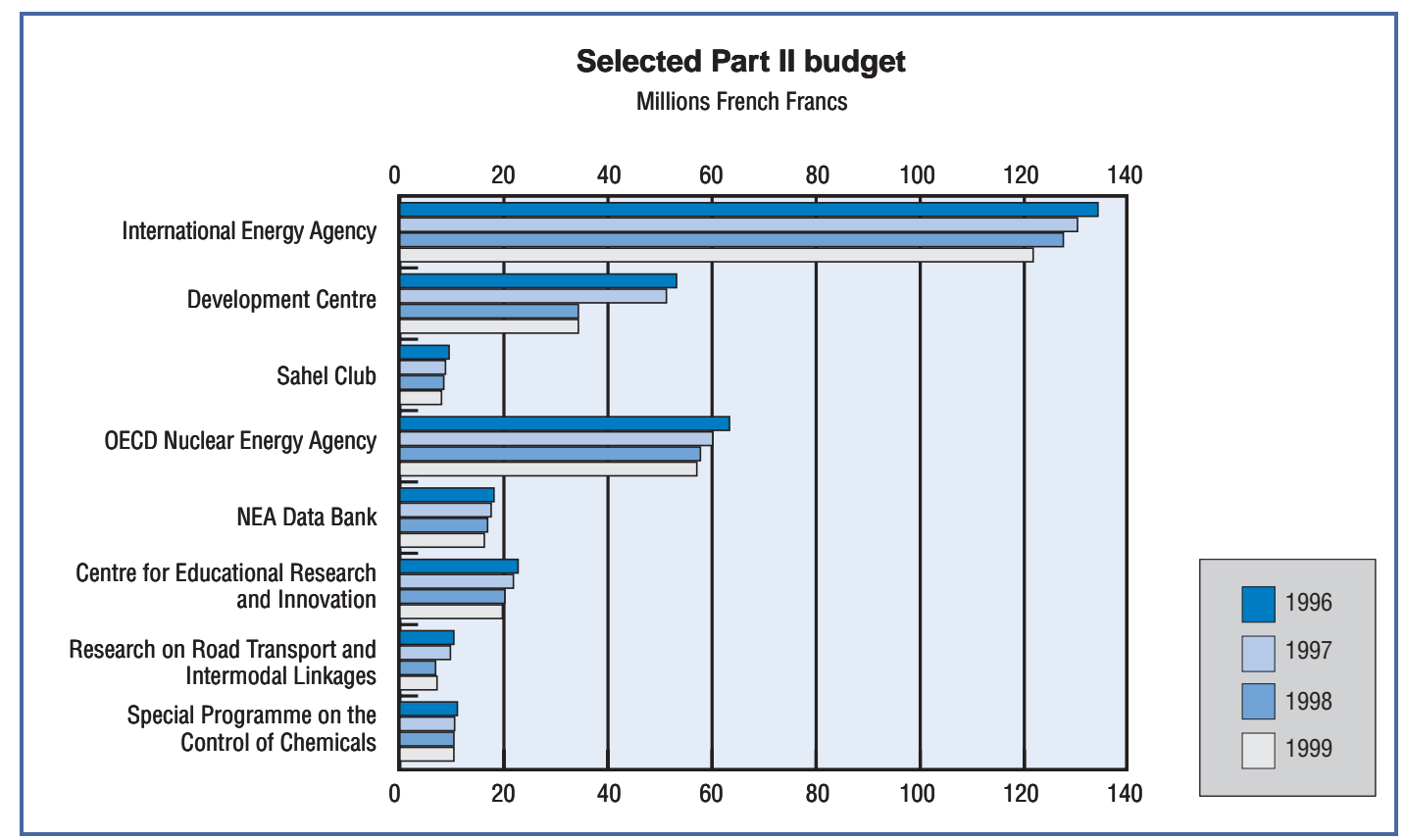

The charts on this and the preceding page show the evolution of the cost of selected Part I and Part II Programmes in recent years, in constant 1999 French francs. 


\section{PUBLIC AFFAIRS AND COMMUNICATIONS}

www.oecd.org/news_and_events/ www.oecd.org/about/

The Public Affairs and Communications Directorate (PAC) contributes to transparency and openness by making information about OECD's work and its results available to the public in a timely manner. PAC also presents "work in progress" on the Internet to elicit public comment.

Management and the staff of the Organisation conduct the OECD's contacts with interested audiences. The Secretary-General, his Deputies, Directors and other staff speak to numerous professional gatherings. They play a central role in briefing and giving interviews to the media. Directorates engage in a continuing dialogue with academics, public policy analysts, other international organisations and non-governmental organisations active in their fields. Directorates also maintain their own sub-sites on the OECD Internet site.

As for PAC itself, the Directorate:

- Publishes and markets the Organisation's books and electronic publications.

- Conducts relations with the media.

- Manages the content of the OECD Internet site.

- Originates and distributes public information materials.

- Publishes the Observer magazine and its annual supplement, OECD in Figures.

- Assists in maintaining relations with business and civil society.
- Conducts the Visits Programme.

- Is responsible for OECD Centres in Bonn/Berlin, Mexico City, Tokyo and Washington.

In June 2000 PAC is organising OECD Forum 2000, a major open international conference to be held in conjunction with the annual meeting of OECD Ministers.

\section{Publishing}

The OECD publishes some 250 books and CD-Roms a year on economic and social topics. These include compilations of statistical data. A major initiative to improve the quality, look and design of flagship publications has been under way over the past two years, culminating with the launch of a new cover look in January 2000, and the grouping of publications into 25 thematic collections.

The Internet is changing publishing practices, including those at the OECD, where three major services using the Internet have been introduced. The OECD Online Bookshop, opened in 1998, received an important upgrade in 1999. New features include online payment coupled with immediate access to an electronic copy of a book. Both usage and sales continue to rise. (www.oecd.org/bookshop)

In 1999 OECD Direct was launched. This free service delivers announcements by e-mail of new books, on publication. Over 5000 users registered during the first six months after the service's introduction. (Registration is via www.oecd.org/bookshop.) 
At the end of 1999 OECD announced its online publishing service, SourceOECD. To be started during 2000, this service will deliver the full text of all publications and access to the statistical databases via the Internet.

OECD's readership is largely composed of professionals, encompassing academics, government officials and the private sector. With SourceOECD and OECD Direct, awareness and usage in these groups will grow, but it is also anticipated that these services will extend the reach of OECD publications to lower-income groups, including students, in both Member and nonmember economies.

\section{Relations with the media}

The breadth and depth of media coverage of OECD work continues to intensify. This is partly due to the efforts of the Media Relations Division and Secretariat officials who are in contact with journalists. But it also reflects the growing complexities of the international economic environment and rising public interest in various elements of the Organisation's activities. These elements include efforts to combat corruption, money laundering and harmful tax-poaching practices; the drive to improve governance at all levels, including company board rooms; and issues relating to crossborder investment and trade. In parallel, the proliferation of media outlets addressing such themes, including both traditional print and broadcast media and new Internet services, has resulted in greatly increased demand for commentary on economic and related issues which the Organisation is well-placed to satisfy.

News releases and news conferences are the traditional vehicles for announcing OECD news. But when the Organisation has information to impart that does not qualify as "news", issue-based briefings and seminars are better tools. They allow ample time for Secre- tariat experts to present the issue, and for discussion and debate. They can be strategically timed and planned sufficiently in advance to secure the right attendance. Another means of drawing attention to OECD's principal public messages is the placement of articles by the Secretary-General and other senior officials in chosen media outlets.

\section{Internet}

Today, the OECD Internet site is the most prominent of its type in terms of the volume and quality of the information provided as well as the number of visits to the site. References to the OECD site can be found in more than 15000 other sites world-wide, and it welcomes over 80000 visitors each month. An intra-Secretariat group is working to further improve the content management, functionalities and user-friendliness of the site. Feedback from external users is being taken into account. To improve public access to OECD work, PAC launched several ad hoc web sites on important topics, including Biotechnology, the Council Meeting at Ministerial level, and Sustainable Development.

\section{Institutional information}

Part of the task of communicating the OECD's message involves preparing information materials capable of conveying the Organisation's analysis and policy conclusions to non-specialist audiences. OECD Policy Briefs are published on major elements of the Organisation's work.

These information products add value to the Visits Programme, which welcomes groups from Member and non-member countries. The programme received some 3500 visitors in 1999. 


P

0

In January 1999 the OECD Observer magazine acquired a new "look" and its editorial approach was overhauled. The result is a magazine that showcases OECD policy research and findings in an approachable, but sober and serious manner.

\section{The OECD Centres}

The OECD Centres in Germany, Japan, Mexico and the United States disseminate OECD information through the sale and distribution of books and electronic products. In addition, the Centres provide information to the media and parliaments, as well as to business, labour and other non-governmental organisations. Information tools, the Centres, publications, and media relations function together in campaigns, which are focused programmes to disseminate a particular message or publication, using all of the Directorate's resources.

\section{Business and civil society}

Like other international organisations, OECD is faced with the challenge of reaching out to "civil society", a term which broadly refers to voluntary associations of all kinds, including organised religion, trade unions, and interest groups. Civil society has gained an enhanced international presence due to the emergence of global issues, such as the environment. Contacts have taken place over many years between OECD and groups concerned about the environment and sustainable development; contacts on other issues continue to expand. Worthy of particular note in this regard were the consultations with civil society representatives on the issues related to biotechnology and food safety. Consultations were held in Paris in November 1999 and in Edinburgh in February-March 2000, at a conference hosted by the UK government.

The Directorate is responsible for relations with the Business and Industry Advisory Committee (BIAC) and the Trade Union Advisory Committee (TUAC). Representatives of these bodies meet periodically with the Council and with committees throughout the Organisation. In addition, the Labour-Management Programme brings business and trade union experts to Paris, usually six times per year, for discussions with the Secretariat on topics related to the current work programme.

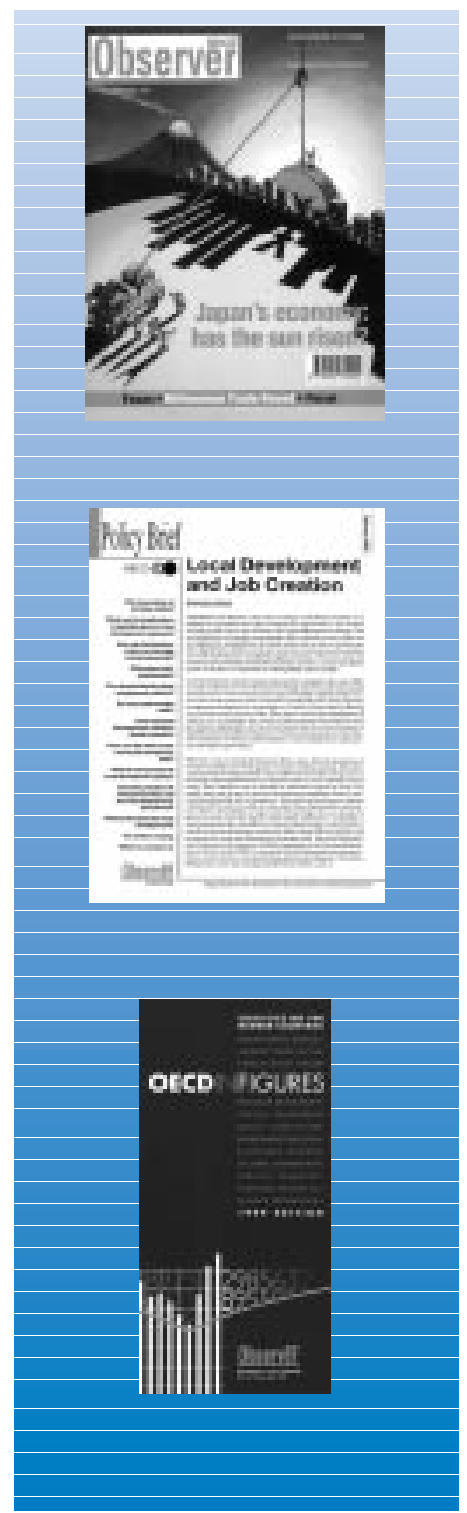




\section{BUSINESS AND INDUSTRY ADVISORY COMMITTEE (BIAC) AND TRADE UNION ADVISORY COMMITTEE (TUAC)}

The OECD's formal relations with the business community and organised labour are conducted with, and through, the Business and Industry Advisory Committee to the OECD (BIAC) and the Trade Union Advisory Committee to the OECD (TUAC).

In 1999, members of both organisations took an active part in the work of various OECD committees and workshops, and held consultations with the Chairs of a large number of OECD bodies, at Ministerial level or at expert level. Participation and consultations included: OECD Conference on Foreign Direct Investment and the Environment; OECD/US Conference on Preparing Youth for the $21^{\text {st }}$ Century: the Policy Lessons from the Past Two Decades; Forum on Climate Change; Review of the OECD Guidelines for Multinational Enterprises; the Council Ministerial meeting; Meeting of the Committee on Scientific and Technological Policy at Ministerial level; Conference on Trade and Competition; and the Paris Conference on Electronic Commerce.

Both BIAC and TUAC met on several occasions with the Secretary-General and senior staff of the Secretariat. Two meetings of the Liaison Committee with Non-Governmental Organisations, chaired by the Secretary-General, were held with the participation of Permanent Representatives of Member countries.
Five consultative meetings were convened in 1999 under the OECD's Labour-Management Programme (LMP) on the following subjects: Labour and Employment Practices in Today's Global Economy: Implications for the OECD Guidelines on Multinational Enterprises; Multinational Enterprises and Environmental Protection: Implications for the OECD Guidelines on Multinational Enterprises; OECD-TUAC Joint Seminar on Local Partnerships and Regional Development (held in Belfast, Northern Ireland); Pension Funds: Public Policy Concerns and Trade Union Strategies; Whistleblowing to Combat Corruption. Each meeting involved the participation of various OECD Directorates. 


\section{Business and Industry Advisory Committee to the OECD (BIAC)}

\section{Executive Board}

\section{Chairman:}

Mr. Jaakko IHAMUOTILA, Member of the Board, Fortum Corporation (Finland)

\section{Vice-Chairmen:}

Mr. Serge GRAVEL, Associé, Gravel, Otto \& Associés (Canada)

Mr. Jacques SAMPRÉ, Directeur Délégué, SANOFI (France)

Dr. Josef SIEGERS, Member of the Executive Board, BDA (Germany)

Mr. Edwin WILLIAMSON, Partner, Sullivan \& Cromwell (United States)

\section{Secretary-General:}

Mr. Douglas C. Worth

13-15, chaussée de la Muette, 75016 Paris

Tel: $+33(0) 142300960$

Fax: + 33 (0) 142887838

E-mail: biac@biac.org

Internet: www.biac.org

\section{Trade Union Advisory Committee to the OECD (TUAC)}

\section{Administrative Committee}

President:

Mr. Robert White, President, Canadian Labour Congress (Canada)

Vice-Presidents:

Mr. Etsuya WASHIO, President of RENGO (Japan)

Mrs. Evy BUVERUD-PEDERSEN, Secretary, Norwegian Confederation of Trade Unions (LO-N-Norway)

General Secretary:

Mr. John Evans

26, avenue de la Grande-Armée, 75017 Paris

Tel: + 33 (0) 147634263

Fax: + 33 (0) 147549828

E-mail: tuac@tuac.org

Internet: www.tuac.org 


\section{SoųceOECD 《(}

\section{www.oecd.org/sourceoecd}

SourceOECD is the new collective brand name for our online services. Available on subscription, SourceOECD will enable institutions, such as universities and large companies, to network the service to their user communities (thus providing access free at the point of use). A pay-as-you-use module will also be available to customers who are not located at a subscribing institution. The OECD is the first intergovernmental organisation to launch such a service, and it has reached the Internet ahead of most private sector publishers as well.

SourceOECD will extend the information distribution system established by the OECD over many years. This system is based upon a network of Official Depository Libraries in all OECD Member countries and the over 400 major libraries world-wide that purchase the complete collection of OECD printed publications. Via this network, plus through individual sales, the OECD distributes over 800000 individual copies of its books and CD-ROMS to readers in both Member and non-member countries each year.

Initially, there will be three services:

- SourceOECD/studies gathers together all OECD books and reports published since January 1998. Delivery via the firm Ingenta at www.ingenta.com.
- SourceOECD/periodicals includes all issues of OECD periodicals from January 1998 onwards, delivery via Ingenta at www.ingenta.com

- SourceOECD/statistics will deliver access to most OECD statistical databases online, using Ivation's Beyond 20/20 web browser.

\section{The OECD Online Bookshop www.oecd.org/bookshop}

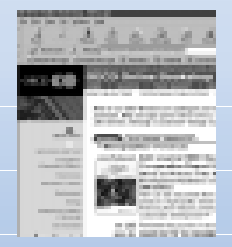

Gateway to our catalogue of books and statistics on CD-ROM. Browseit is our new online service for selected

books, which allows the customer to scroll through the pages of the book on screen (in pdf format) before buying.

Buyit-Readit is our online service for most books. If the customer orders a paperback and pays for it online, we offer the choice of downloading the file free of charge, making the book available immediately. The hard copy will arrive in the post. Or they may buy only the file and not the paperback.

\section{OECD Direct}

This free alert service delivers announcements by e-mail of new books, on publication. Customers choose the themes that suit their interests. Registration is via www.oecd.org/bookshop

\section{Better books, better design, better organisation}

As heralded in last year's Annual Report, 1999 was a year of improvement for the publishing programme. In addition to three major initiatives using the Internet described above, emphasis has been put on improving the look and feel of the printed publications. The result is the launch, from the beginning of 2000 , of our new set of 25 thematic collections under a strong, new, visual identity.

\section{Common image, individual identity}

All OECD publications now share a single visual image that strongly and immediately identifies them with the OECD. At the same time each book's individual identity is preserved. This rigid-flexible system is built around the new OECD logo. The logo's chevrons are repeated at the top of every cover to give a distinctive common "look" to all books. The chevrons also provide a graphical "link" between the title and the book's own illustration. The illustrations ensure that the ideas, concepts or subject of each book will be instantly understood. The overall result is a creative balance between a branded, institutional look needed to reinforce the common heritage of all OECD publications and the creative individualism each book needs to stand out from the crowd. 


\section{The collections are}

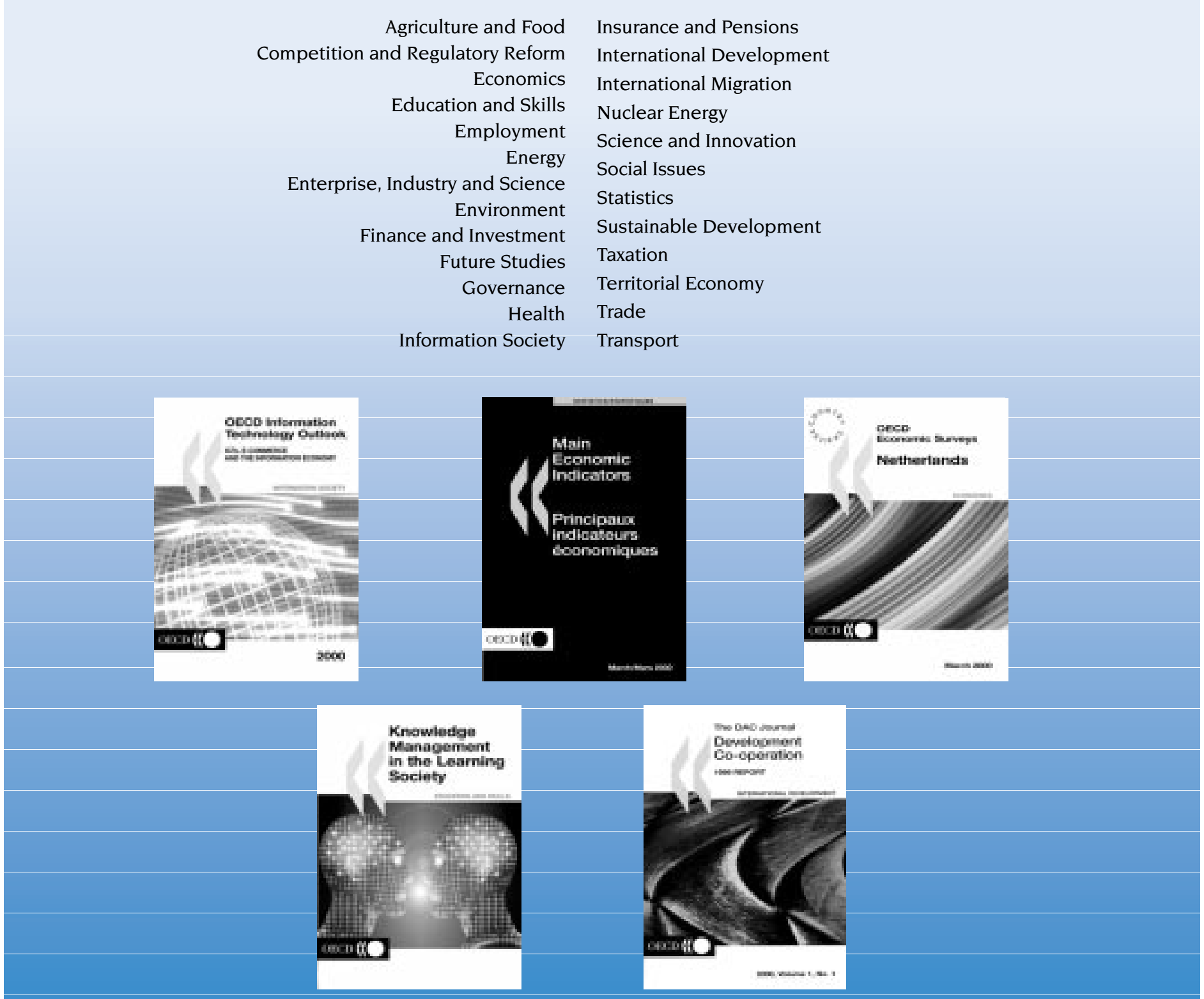


GENERAL SECRETARIAT

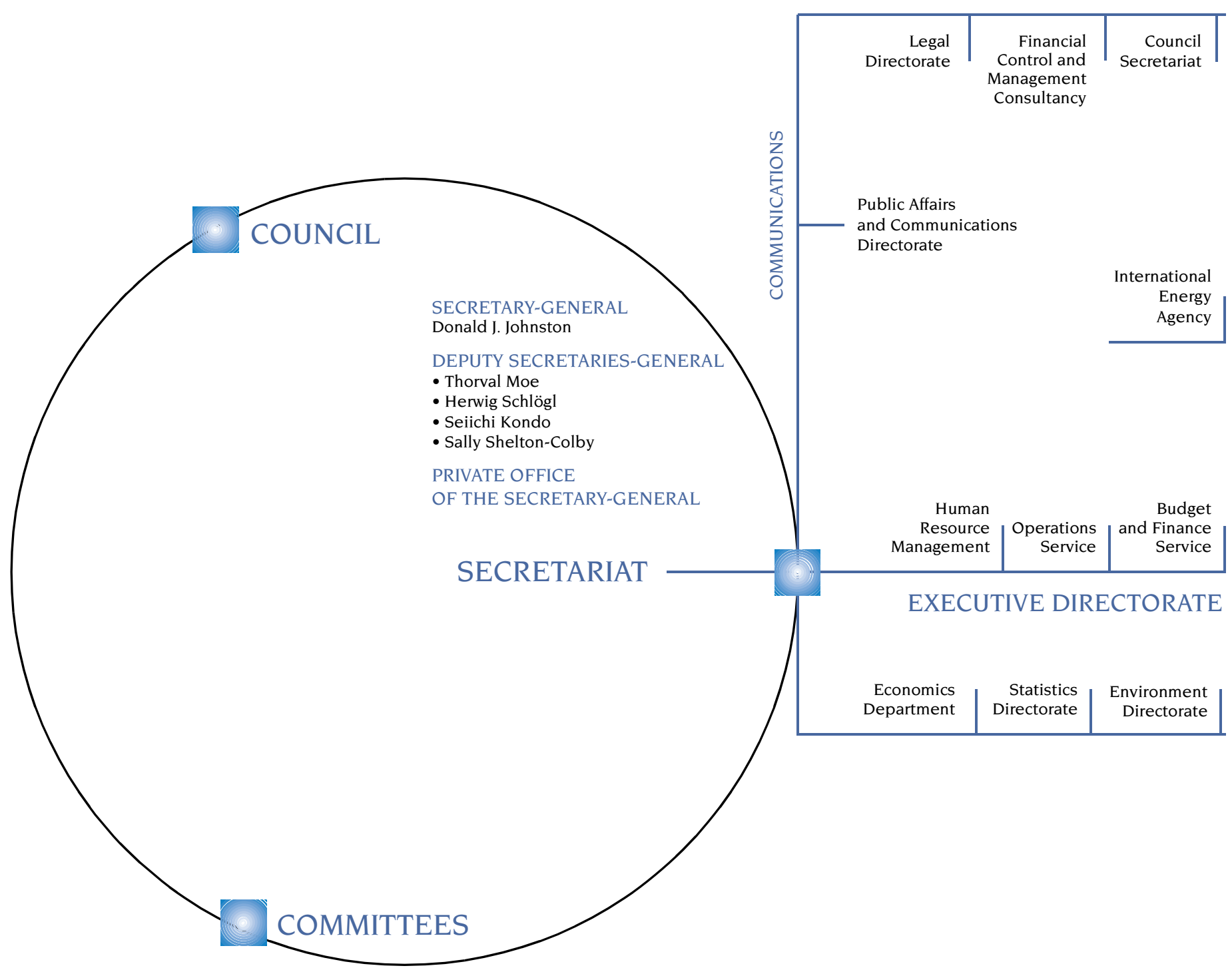




\begin{tabular}{|r|r|}
\hline Advisory & Centre for \\
Unit on & Co-operation \\
with \\
Multidisciplinary \\
Issues & Non-members
\end{tabular}

\begin{tabular}{|c|c|c|c|c|}
\hline & European & & Centre & \\
\hline Nuclear & Conference & & for Educational & \\
\hline Energy & of Ministers & Development & Research & Club \\
\hline Agency & of Transport & Centre & and Innovation & du Sahel \\
\hline
\end{tabular}

\section{SEMI-AUTONOMOUS BODIES}

\begin{tabular}{rr}
$\begin{array}{r}\text { Information } \\
\text { Technology }\end{array}$ & $\begin{array}{r}\text { Language } \\
\text { and }\end{array}$ \\
and Network & $\begin{array}{r}\text { Conference } \\
\text { Services }\end{array}$ \\
\hline
\end{tabular}

\begin{tabular}{|c|c|c|c|c|c|c|c|}
\hline $\begin{array}{r}\text { Development } \\
\text { Co-operation } \\
\text { Directorate }\end{array}$ & $\begin{array}{r}\text { Public } \\
\text { Management } \\
\text { Service }\end{array}$ & $\begin{array}{r}\text { Trade } \\
\text { Directorate }\end{array}$ & $\begin{array}{r}\text { Directorate } \\
\text { for Financial, } \\
\text { Fiscal and } \\
\text { Enterprise Affairs }\end{array}$ & $\begin{array}{r}\text { Directorate } \\
\text { for Science, } \\
\text { Technology } \\
\text { and Industry }\end{array}$ & $\begin{array}{r}\text { Directorate } \\
\text { for Education, } \\
\text { Employment, } \\
\text { Labour and } \\
\text { Social Affairs }\end{array}$ & $\begin{array}{r}\text { Directorate } \\
\text { for Food, } \\
\text { Agriculture } \\
\text { and Fisheries }\end{array}$ & $\begin{array}{r}\text { Territorial } \\
\text { Development } \\
\text { Service }\end{array}$ \\
\hline
\end{tabular}

\section{OECD ORGANISATION CHART IN MARCH 2000}




\section{THE OECD SECRETARIAT}

\author{
MARCH 2000
}

SECRETARY-GENERAL

Donald J. Johnston

Deputy Secretaries-General

Thorvald Moe

Herwig Schlögl

Seiichi Kondo

Sally Shelton-Colby

Head of the Private Office of THE SECRETARY-GENERAL Carolyn Ervin

HeAd of Council SeCRetariat Roger Harmel

EXECUTIVE DiRector Michel David (a.i.)

Financial Controller José Soromenho-Ramos

Public AfFairs

AND COMmunications

Christopher W. Brooks

Advisory UnIT

ON Multidisciplinary Issues

Wolfgang Michalski

LEGal Directorate

David Small

CEnTRE FOR CO-OPERATION

With Non-Members

Eric Burgeat
ECONOMICS DEPARTMENT

Ignazio Visco

STATISTICS

Louis Kincannon

ENVIRONMENT

Joke Waller-Hunter

DeVElopment Co-operation

Richard Carey (a.i.)

Public Management

Geraldine Byrne-Nason (a.i.)

TRADE

Jean-Marie Metzger

FINANCIAL, FISCAL

AND ENTERPRISE AFFAIRS

William Witherell

Science, Technology And Industry Risaburo Nezu

EducATION, EMPLOYMENT,

LABOUR ANd Social AfFairs

John Martin

Food, Agriculture And Fisheries Gérard Viatte

TERritorial DeVELopment

Bernard Hugonnier

Human Resource Management Pierre Lebleu
Operations

David Johnson

Budget And Finance

Anthony Rottier (a.i.)

INFORMATION TECHNOLOGY AND NetWork SERVICES

Guido Maccari

Language and Conference Service Thomas Afton

International EnERGy AgEncy Robert Priddle

Nuclear Energy Agency

Luis Echavarri

Development Centre

Jorge Braga de Macedo

Club du SAHEl

Jacqueline Damon

Centre for Educational Research AND INNOVATION

John Martin

European CONFERENCE of Ministers of TRANSPORT

Gerhard Aurbach 


\section{AMBASSADORS, PERMANENT REPRESENTATIVES TO THE OECD}

\section{MARCH 2000}

AustraLIA

His Excellency Mr. Anthony Hinton

AUSTRIA

His Excellency Mr. Karl Schramek

BeLgium

His Excellency Mr. Pierre-Dominique Schmidt

CANADA

Her Excellency Ms. Suzanne Hurtubise

Czech Republic

His Excellency Mr. Jaromír Prívratský

DENMARK

His Excellency Mr. Flemming Hedegaard

FINLAND

His Excellency Mr. Illka Ristimäki

FRANCE

Her Excellency Ms. Joelle Bourgois

GERMANY

His Excellency Mr. Werner Kaufmann-Bühler

GREECE

His Excellency Mr. Spyros Lioukas

HUNGARY

His Excellency Mr. Béla Kádár

ICELAND

Her Excellency Ms. Sigridur Asdis Snaevarr

IRELAND

His Excellency Mr. Patrick O'Connor

ITALY

His Excellency Mr. Alessandro Vattani

JAPAN

His Excellency Mr. Mutsuyoshi Nishimura
KOREA

His Excellency Mr. Soogil Young

LUXEMBOURG

His Excellency Mr. Jean-Marc Hoscheit

MeXIco

Mr. Gerado Lozano (a.i.)

NetHeRLANDS

His Excellency Mr. Egbert Jacobs

NEW ZEALAND

His Excellency Mr. Richard Grant

NORWAY

His Excellency Mr. Per Ludvig Magnus

POLAND

His Excellency Mr. Jan Woroniecki

PORTUGAL

His Excellency Mr. Jorge de Lemos Godinho

SPAIN

His Excellency Mr. José Luis Feito

SWEDEN

His Excellency Mr. Anders Ferm

SWITZERLAND

His Excellency Mr. Jean-Pierre Zehnder

TURKEY

His Excellency Mr. Akin Alptuna

UnITED KINGDOM

His Excellency Mr. Christopher Crabbie, CMG

United STATES

Her Excellency Ms. Amy Bondurant

EUROPEAN COMMISSION

His Excellency Mr. Piergiorgio Mazzocchi 


\section{OECD $\$$ OCDE}

\section{OECD MEMBER COUNTRIES}

\begin{tabular}{|c|c|}
\hline & \\
AUSTRALIA & KOREA \\
AUSTRIA & LUXEMBOURG \\
BELGIUM & MEXICO \\
CANADA & NETHERLANDS \\
CZECH REPUBLIC & NEW ZEALAND \\
DENMARK & NORWAY \\
FINLAND & POLAND \\
FRANCE & PORTUGAL \\
GERMANY & SPAIN \\
GREECE & SWEDEN \\
HUNGARY & SWITZERLAND \\
ICELAND & TURKEY \\
IRELAND & UNITED KINGDOM \\
ITALY & UNITED STATES \\
JAPAN & \\
& \\
\hline $\mathbf{1 2 0}$ & \\
\hline
\end{tabular}




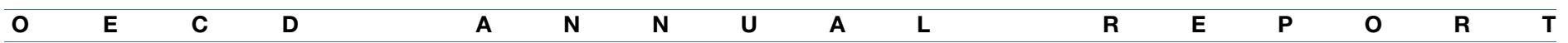

OECD PUBLICATIONS, 2, rue André Pascal, 75775 PARIS CEDEX 16 - № 807132000 PRINTED IN FRANCE

121 
